Nevada

Environmental Management

Operations Activity

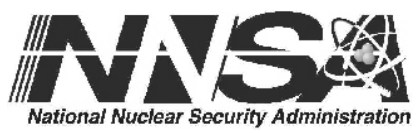

Closure Report for

Corrective Action Unit 366:

Area 11 Plutonium Valley

Dispersion Sites,

Nevada National Security Site,

Nevada

Controlled Copy No::

Revision: 0

December 2013

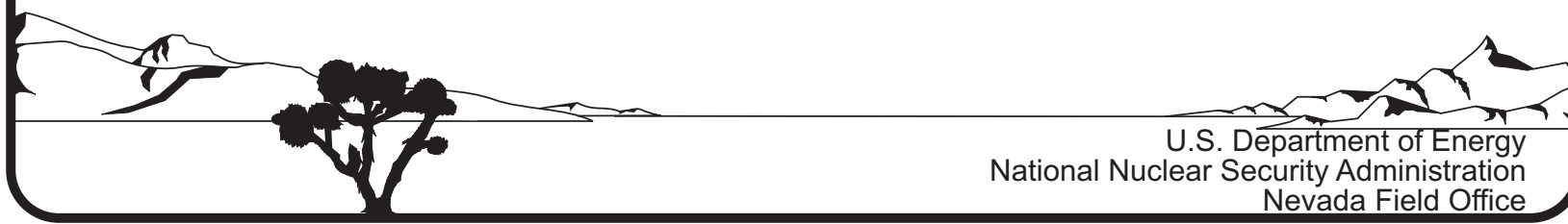




\section{DISCLAIMER}

Reference herein to any specific commercial product, process, or service by trade name, trademark, manufacturer, or otherwise, does not necessarily constitute or imply its endorsement, recommendation, or favoring by the United States Government or any agency thereof.

This report has been reproduced directly from the best available copy.

Available for sale to the public from:

U.S. Department of Commerce

National Technical Information Service

5301 Shawnee Road

Alexandria, VA 22312

Telephone: (800) 553-6847

Fax: (703) 605-6900

E-mail: orders@ntis.gov

Online ordering: http://www.ntis.gov/help/ordermethods.aspx

Available electronically at http://www.osti.gov/bridge.

Available for a processing fee to the U.S. Department of Energy and its contractors, in paper, from:

U.S. Department of Energy

Office of Scientific and Technical Information

P.O. Box 62

Oak Ridge, TN 37831-0062

Telephone: (865) 576-8401

Fax: (865) 576-5728

E-mail: reports@adonis.osti.gov 


\title{
CLOSURE REPORT FOR CORRECTIVE ACTION UNIT 366: AREA 11 PLUTONIUM VALLEY DISPERSION SITES, NEVADA NATIONAL SECURITY SITE, NEVADA
}

\author{
U.S. Department of Energy \\ National Nuclear Security Administration \\ Nevada Field Office \\ Las Vegas, Nevada
}

Controlled Copy No.

Revision: 0

December 2013 
THIS PAGE INTENTIONALLY LEFT BLANK 


\section{CLOSURE REPORT FOR CORRECTIVE ACTION UNIT 366: AREA 11 PLUTONIUM VALLEY DISPERSION SITES, NEVADA NATIONAL SECURITY SITE, NEVADA}

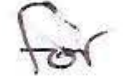

Approved By: Is/: Robert F. Boehlecke for Tiffany A. Lantow Date: $12 / 19 / 13$

Approved By: Is/: Robert F. Boehlecke Date: $12 / 19 / 13$ 
THIS PAGE INTENTIONALLY LEFT BLANK 


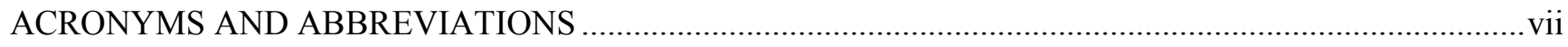

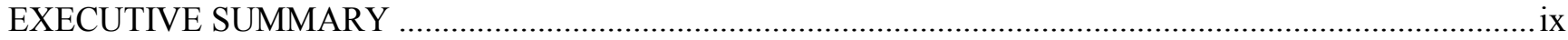

1.0 INTRODUCTION

1.1 PURPOSE

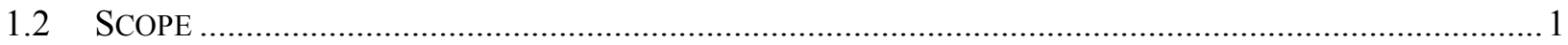

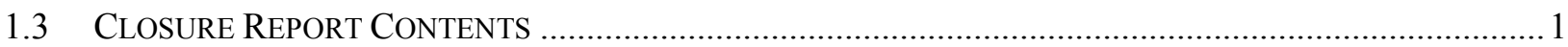

1.3.1 Applicable Programmatic Plans and Documents ............................................................ 3

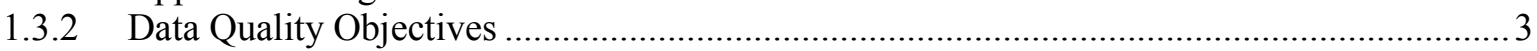

1.3.3 Data Quality Assessment........................................................................................ 3

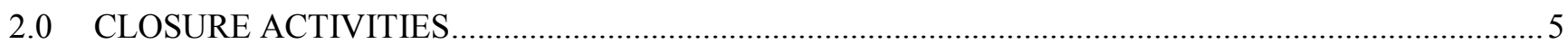

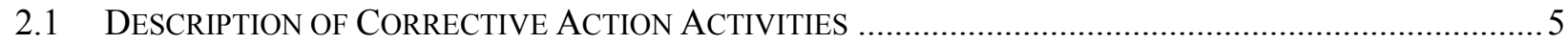

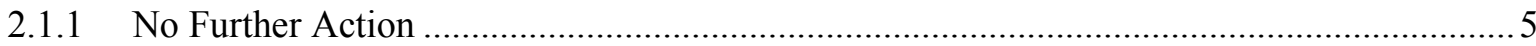

2.1.1.1 Corrective Action Site 11-23-01, Radioactively Contaminated Area A ..................5

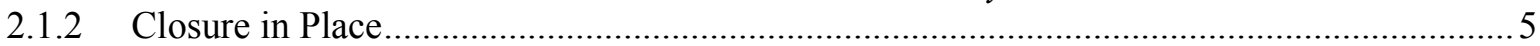

2.1.2.1 Corrective Action Site 11-08-01, Contaminated Waste Dump \#1 .........................5

2.1.2.2 Corrective Action Site 11-08-02, Contaminated Waste Dump \#2 ......................... 7

2.1.2.3 Corrective Action Site 11-23-02, Radioactively Contaminated Area B ................. 9

2.1.2.4 Corrective Action Site 11-23-03, Radioactively Contaminated Area C................. 9

2.1.2.5 Corrective Action Site 11-23-04, Radioactively Contaminated Area D ................ 9

2.1.3 Best Management Practices............................................................................................ 10

2.2 DEVIATIONS FROM THE CORRECTIVE ACTION PLAN AS APPROVED.......................................... 10

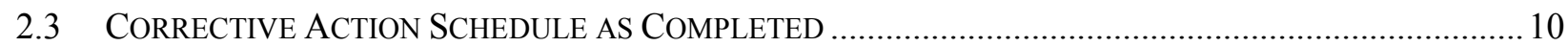

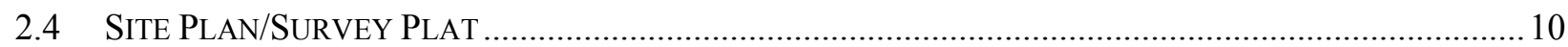

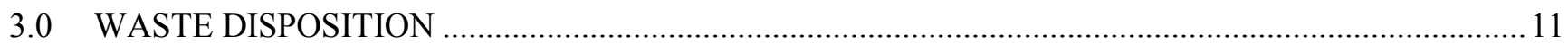

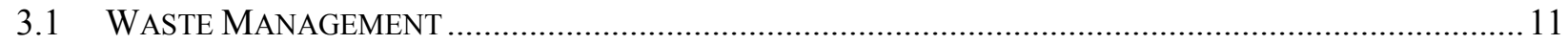

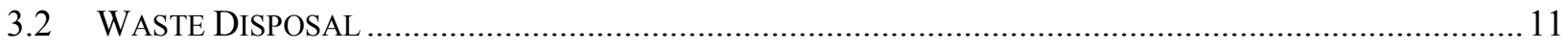

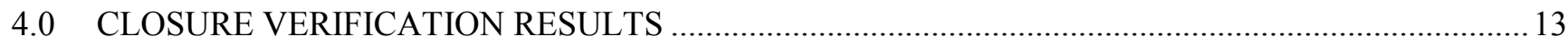

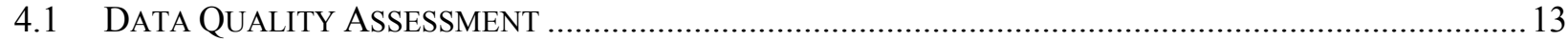

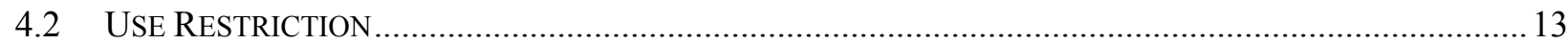

4.2.1 Corrective Action Site 11-08-01, Contaminated Waste Dump \#1 ................................... 13

4.2.2 Corrective Action Site 11-08-02, Contaminated Waste Dump \#2 ................................... 13

4.2.3 Corrective Action Site 11-23-02, Radioactively Contaminated Area B ............................ 13

4.2.4 Corrective Action Site 11-23-03, Radioactively Contaminated Area C ............................ 13

4.2.5 Corrective Action Site 11-23-04, Radioactively Contaminated Area D ............................ 14

4.2.6 Administrative Use Restriction ................................................................................. 14

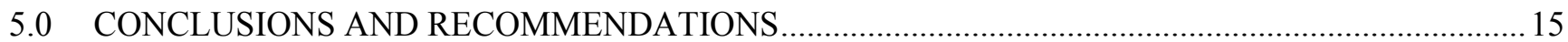

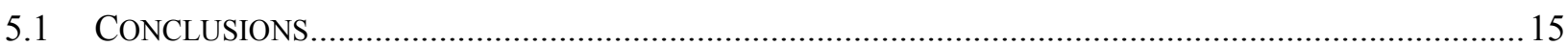

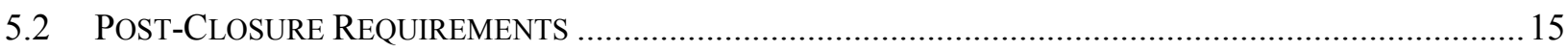

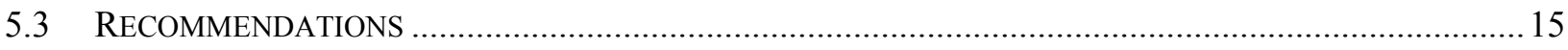

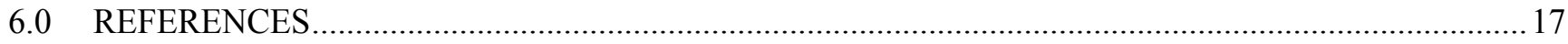

LIBRARY DISTRIBUTION LIST 


\section{TABLE OF CONTENTS (continued)}

\section{LIST OF FIGURES}

Figure 1. Corrective Action Unit 366 Site LocAtion MAP ..........................................................2

FIGURE 2. CORRECTIVE ACTION UNIT 366 USE RESTRICTION BOUNDARIES ......................................6

Figure 3. CurRent Contaminated WASte Dump RAdiological Postings ...................................8

\section{APPENDICES}

ApPEndix A. DATA Quality OBJECTIVES

APPENDIX B. WASTE DiSPOSITION DOCUMENTATION

APPENDiX C. Site Closure PhOtOGRAPHS

APPENDIX D. USE RESTRICTION DOCUMENTATION

Appendix E. Nevada Division of Environmental Protection Comment Response Form 
BMP best management practice

CA Contamination Area

CAA corrective action alternative

CAI corrective action investigation

CAIP Corrective Action Investigation Plan

CAP Corrective Action Plan

CAS Corrective Action Site

CAU Corrective Action Unit

CR Closure Report

CSM conceptual site model

CWD Contaminated Waste Dump

DOE U.S. Department of Energy

DQA data quality assessment

DQO data quality objective

FAL final action level

FFACO Federal Facility Agreement and Consent Order

$\mathrm{ft} \quad$ foot (feet)

HCA High Contamination Area

in. $\quad$ inch(es)

LLW low-level waste

$\mathrm{M} \& \mathrm{O} \quad$ Management and Operations

mrem/IA-yr millirem(s) per Industrial Area year

mrem/OU-yr millirem(s) per Occasional Use Area year

NDEP Nevada Division of Environmental Protection

NNSA/NFO U.S. Department of Energy, National Nuclear Security Administration Nevada Field Office

NNSA/NSO U.S. Department of Energy, National Nuclear Security Administration Nevada Site Office

NNSS Nevada National Security Site

PPE personal protective equipment

RadCon Radiological Control 


\section{ACRONYMS AND ABBREVIATIONS (continued)}

RMA Radioactive Material Area

RWMS Radioactive Waste Management Site

TED total effective dose

WMA waste management area

UR use restriction

URMA Underground Radioactive Material Area 
This Closure Report (CR) presents information supporting closure of Corrective Action Unit (CAU) 366, Area 11 Plutonium Valley Dispersion Sites, and provides documentation supporting the completed corrective actions and confirmation that closure objectives for CAU 366 were met. This CR complies with the requirements of the Federal Facility Agreement and Consent Order (FFACO) that was agreed to by the State of Nevada; the U.S. Department of Energy (DOE), Environmental Management; the U.S. Department of Defense; and DOE, Legacy Management (FFACO, 1996 as amended). CAU 366 consists of the following six Corrective Action Sites (CASs), located in Area 11 of the Nevada National Security Site:

- CAS 11-08-01, Contaminated Waste Dump \#1

- CAS 11-08-02, Contaminated Waste Dump \#2

- CAS 11-23-01, Radioactively Contaminated Area A

- CAS 11-23-02, Radioactively Contaminated Area B

- CAS 11-23-03, Radioactively Contaminated Area C

- CAS 11-23-04, Radioactively Contaminated Area D

Closure activities began in January 2013 and were completed in June 2013. Activities were conducted according to the Corrective Action Plan for CAU 366 (U.S. Department of Energy, National Nuclear Security Administration Nevada Field Office [NNSA/NFO], 2013). The corrective actions included no further action and closure in place. Soil covers approximately 3 feet thick were constructed at CAS 11-08-01 over Contaminated Waste Dump (CWD) \#1 and at CAS 11-08-02 over CWD \#2. Engineering designs were not required for construction of the soil covers. FFACO use restrictions (URs) were implemented for areas where the total effective dose (TED) exceeds the final action level of 25 millirems per Occasional Use Area year. The FFACO URs are located within the large, fenced Contamination Area (CA) that encompasses Plutonium Valley. UR warning signs were posted along the existing CA fence and at the locked gate on the road leading to the site. An administrative UR was implemented as a best management practice for the areas where the TED exceeds 25 millirems per Industrial Area year and where removable contamination is present at levels that require the area to be posted and controlled as a CA. Closure activities generated low-level waste that met land disposal restrictions and was disposed of in an onsite landfill.

NNSA/NFO requests the following:

- A Notice of Completion from the Nevada Division of Environmental Protection to NNSA/NFO for closure of CAU 366

- The transfer of CAU 366 from Appendix III to Appendix IV, Closed Corrective Action Units, of the FFACO 
CAU 366 Closure Report

Section: Executive Summary

Revision: 0

Date: December 2013

THIS PAGE INTENTIONALLY LEFT BLANK 
This Closure Report (CR) documents closure activities for Corrective Action Unit (CAU) 366, Area 11 Plutonium Valley Dispersion Sites, according to the Federal Facility Agreement and Consent Order (FFACO, 1996 as amended). CAU 366 consists of the following six Corrective Action Sites (CASs), located in Area 11 of the Nevada National Security Site (NNSS) (Figure 1):

- CAS 11-08-01, Contaminated Waste Dump \#1

- CAS 11-08-02, Contaminated Waste Dump \#2

- CAS 11-23-01, Radioactively Contaminated Area A

- CAS 11-23-02, Radioactively Contaminated Area B

- CAS 11-23-03, Radioactively Contaminated Area C

- CAS 11-23-04, Radioactively Contaminated Area D

\subsection{Purpose}

This CR provides justification for closure of CAU 366 without further corrective action based on corrective actions completed in accordance with the Corrective Action Plan (CAP) for CAU 366 (U.S. Department of Energy, National Nuclear Security Administration Nevada Field Office [NNSA/NFO], 2013). This CR provides a summary of completed closure activities, documentation supporting corrective actions, and confirmation that closure objectives were met.

\subsection{SCOPE}

The following corrective actions were implemented for CAU 366:

- No further action for CAS 11-23-01

- Closure in place for CASs 11-08-01, 11-08-02, 11-23-02, 11-23-03, and 11-23-04

\subsection{Closure Report Contents}

This CR includes the following sections:

- Section 1.0: Introduction

- Section 2.0: Closure Activities

- Section 3.0: Waste Disposition

- Section 4.0: Closure Verification Results

- Section 5.0: Conclusions and Recommendations

- Section 6.0: References

- Appendix A: Data Quality Objectives

- Appendix B: Waste Disposition Documentation

- Appendix C: Site Closure Photographs

- Appendix D: Use Restriction Documentation

- Appendix E: Nevada Division of Environmental Protection Comment Response Form 


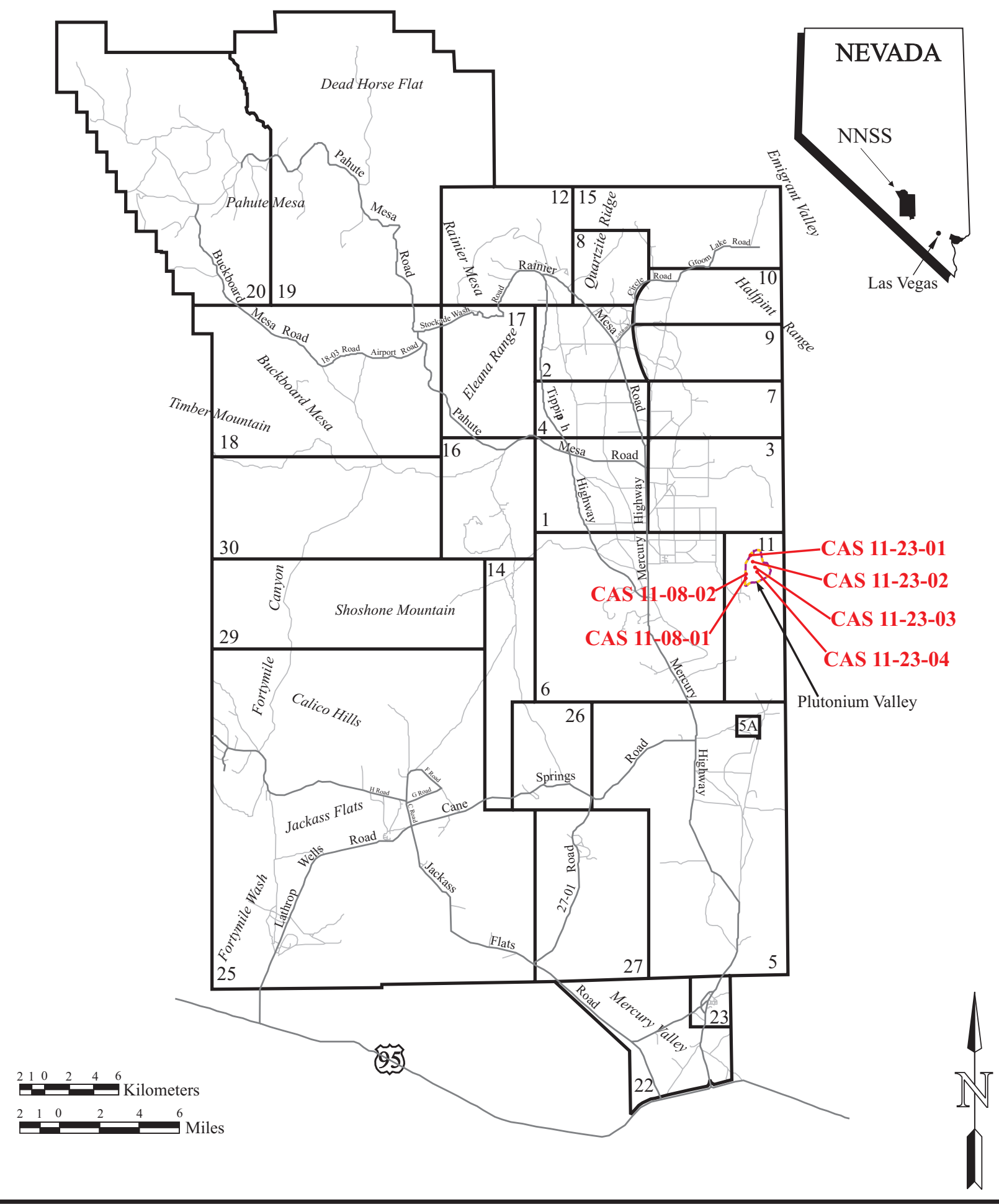

Figure 1. Corrective ACtion Unit 366 Site Location MaP 


\subsubsection{Applicable Programmatic Plans and Documents}

Closure activities were performed in accordance with the CAP for CAU 366 (NNSA/NFO, 2013).

\subsubsection{Data Quality Objectives}

Data quality objectives (DQOs) were developed for CAU 366 in the Corrective Action Investigation Plan (CAIP) (U.S. Department of Energy, National Nuclear Security Administration Nevada Site Office [NNSA/NSO], 2011). The DQOs are included in Appendix A of this report exactly as presented in the CAIP, as dictated by the FFACO outline for a CR. The DQOs were designed to ensure that the data collected during the corrective action investigation (CAI) would provide sufficient and reliable information to identify, evaluate, and technically defend recommended corrective action alternatives (CAAs). A conceptual site model (CSM) was developed to organize and communicate information about site characteristics. The CSM defines the assumptions that are the basis for identifying appropriate sampling strategy and data collection methods. An accurate CSM is important as it serves as the basis for all subsequent inputs and decisions throughout the DQO process.

The CSM established that the CAU 366 area is inactive and/or abandoned, and the exposure scenario was categorized as Occasional Use Area, which assumes that the future use of the area includes occasional and temporary work activities and that workers will not be assigned to the area on a regular basis. A site worker under this scenario is assumed to be on site for a maximum of 80 hours per year for 5 years (NNSA/NSO, 2011).

Sources of potential contamination were identified and include buried radiologically contaminated debris, atmospheric deposition of radionuclides from the four safety experiments that were conducted in the area, radiologically contaminated debris present on the surface, effluent from decontamination station and hot park activities, and washes and drainages flowing through the site (NNSA/NSO, 2011).

The data collected during the CAI supported the CSM as presented in the CAIP. No revisions to the CSM were necessary, and the CSM was confirmed during closure activities.

\subsubsection{Data Quality Assessment}

A data quality assessment (DQA) was performed to determine the degree of acceptability and usability of the reported data in the decision-making process and to determine whether the DQO criteria established in the CAIP were met and whether DQO decisions can be resolved at the desired level of confidence. The results of the DQA were presented in Appendix B of the Corrective Action Decision Document (NNSA/NSO, 2012a).

Data were assessed against the acceptance criteria for the data quality indicators of precision, accuracy, representativeness, comparability, and completeness, as defined in the Soils Quality Assurance Plan (NNSA/NSO, 2012b). The results of the evaluation show that the data were of sufficient quality to make the DQO decisions. The DQA determined that information generated during the CAI supported the CSM assumptions, the data collected supported their intended use in the decision-making process, and DQO requirements were met. Based on the results of the DQA, the nature and extent of contamination at CAU 366 were adequately identified so that CAAs could be developed and evaluated (NNSA/NSO, 2012a). 
CAU 366 Closure Report

Section: Introduction

Revision: 0

Date: December 2013

THIS PAGE INTENTIONALLY LEFT BLANK 


\subsection{CLOSURE ACTIVITIES}

This section includes a description of the closure activities performed for CAU 366, deviations from the CAP, and schedule of completed field work.

\subsection{Description OF CORRECTIVE ACTION ACTIVITIES}

The following sections describe the closure activities completed for CAU 366.

\subsubsection{No Further Action}

\subsubsection{Corrective Action Site 11-23-01, Radioactively Contaminated Area A}

This site consists of soil impacted by surface safety experiment Project 56 No. 1, a device primarily containing enriched uranium that was detonated with zero yield on November 1, 1955, at Test Area 11a. No radiological contamination was identified at Test Area 11a that exceeds the final action level (FAL) of 25 millirems per Occasional Use Area year (mrem/OU-yr); therefore, CAS 11-23-01 was closed with no further action. Although no further action was required, this site is located within the administrative use restriction (UR) that was implemented as a best management practice (BMP), as described in Section 2.1.3.

\subsubsection{Closure in Place}

\subsubsection{Corrective Action Site 11-08-01, Contaminated Waste Dump \#1}

Contaminated Waste Dump (CWD) \#1 was used to dispose of radiologically contaminated debris associated with test activities. The CWD originally measured approximately 105 by 93 feet (ft). CWD \#1 is located within the large Contamination Area (CA) that encompasses Plutonium Valley. Before closure activities began, the CWD was posted as an Underground Radioactive Material Area (URMA).

A 3-ft thick soil cover was constructed over CWD \#1. An engineering design was not required for construction of the soil cover. To facilitate construction activities and allow for heavy equipment and personnel access with less stringent controls, a buffer area in the CA surrounding the CWD was downposted from a CA to a Radioactive Material Area (RMA). Before construction began, radiological surveys were performed in the buffer area. Clean fill was placed as needed in areas that exceeded the CA criteria for removable contamination so that the area could be downposted to an RMA. To construct the cover, clean soil was placed over the CWD in lifts of approximately 6 inches (in.) and wheel rolled for compaction until the thickness of $3 \mathrm{ft}$ was achieved. The edges of the cover were contoured to a slope of approximately $2: 1$. Concrete monuments were installed at the corners of the soil cover.

A FFACO UR was implemented for radiological contaminants that are assumed to be present within CWD \#1 at levels exceeding the FAL of $25 \mathrm{mrem} / \mathrm{OU}-\mathrm{yr}$. The UR boundary encompasses the soil cover and a mound containing buried metallic debris adjacent to CWD \#1. Figure 2 shows the UR boundary for CAS 11-08-01. UR warning signs were attached to the concrete monuments located at the corners of the soil cover. 


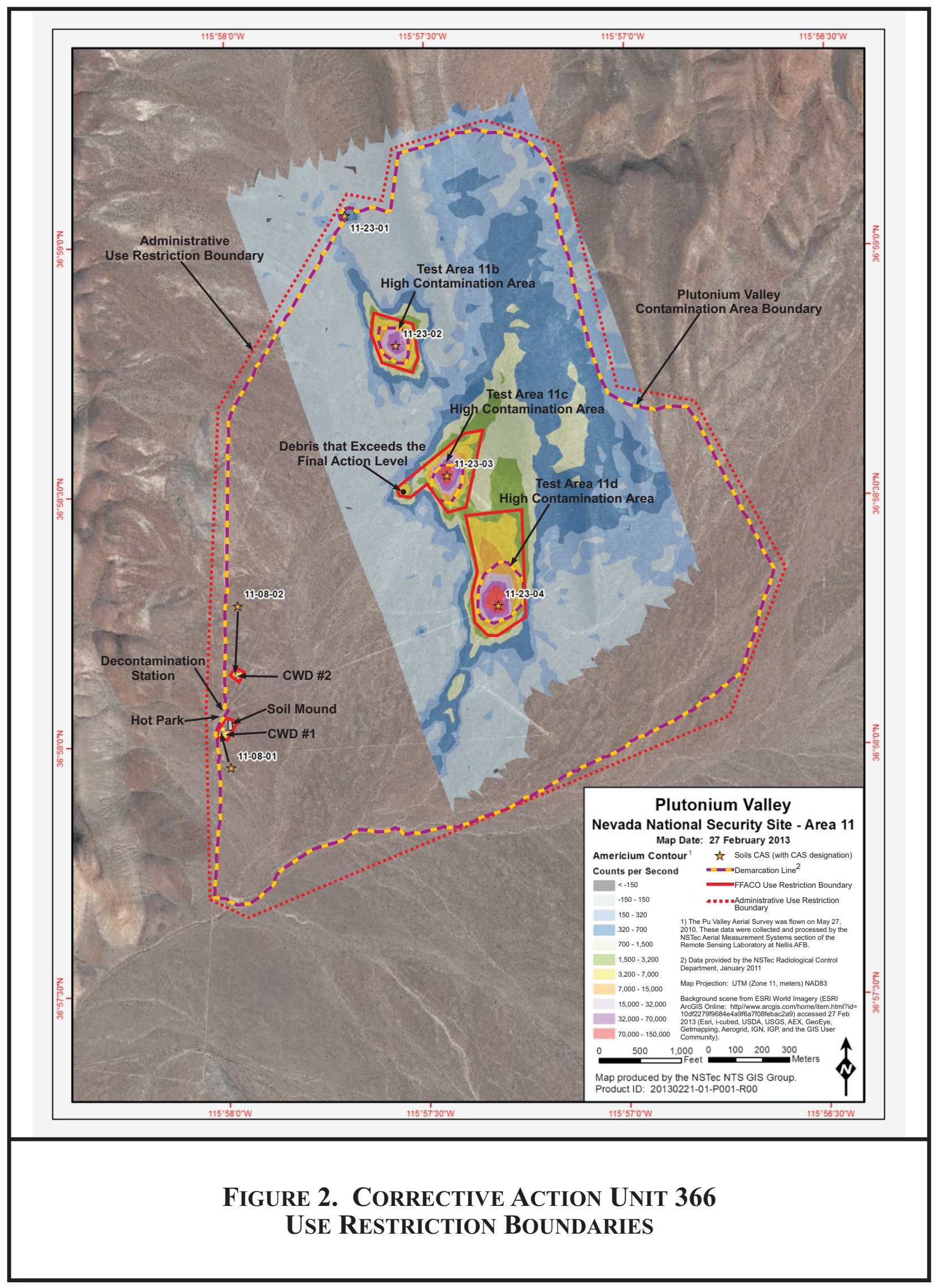


After construction of the cover was complete, CWD \#1 and the surrounding buffer area were posted per the Radiological Control (RadCon) Manual (Radiological Control Managers' Council, 2012). The soil cover was posted as an URMA, and the surrounding buffer area was posted as an RMA. Figure 3 is included to depict the configuration of the current posted radiological areas. The borders of these areas are indicated on the map as "Demarcation Lines." The boundaries of the radiologically posted areas and type of posting (e.g., CA, URMA, RMA) are determined based on the guidelines and limits in the RadCon Manual. While radiological demarcation and postings activities are outside the scope of FFACO closure of CAU 366, because the boundaries changed to facilitate closure activities, this information is included and shown in Figure 3.

\subsubsection{Corrective Action Site 11-08-02, Contaminated Waste Dump \#2}

CWD \#2 was used to dispose of radiologically contaminated debris associated with test activities. The CWD originally measured approximately 92 by $78 \mathrm{ft}$. CWD \#2 is located within the large CA that encompasses Plutonium Valley. Before closure activities began, the CWD was posted as a High Contamination Area (HCA), and partially buried debris was visible within the boundary of CWD \#2.

A 3-ft thick soil cover was constructed over CWD \#2. An engineering design was not required for construction of the soil cover. To facilitate construction activities and allow for heavy equipment and personnel access with less stringent controls, a buffer area in the CA surrounding the CWD and the existing road in the CA leading to the CWD were downposted from a CA to an RMA. Before construction began, radiological surveys were performed in the buffer area and on the road. Clean fill was placed as needed in areas that exceeded the CA criteria for removable contamination so that the areas could be downposted to an RMA. To construct the cover, clean soil was placed over the CWD in lifts of approximately 6 in. and wheel rolled for compaction until the thickness of $3 \mathrm{ft}$ was achieved. The edges of the cover were contoured to a slope of approximately 2:1. Concrete monuments were installed at the corners of the soil cover.

A FFACO UR was implemented for radiological contaminants that are assumed to be present within CWD \#2 at levels exceeding the FAL of $25 \mathrm{mrem} / \mathrm{OU}-\mathrm{yr}$. The UR boundary encompasses the soil cover. Figure 2 shows the UR boundary for CAS 11-08-02. UR warning signs were attached to the concrete monuments located at the corners of the soil cover.

After construction of the cover was complete, CWD \#2, the surrounding buffer area, and the access road were posted per the RadCon Manual (Radiological Control Managers' Council, 2012). The soil cover was posted as an URMA, and the access road and buffer area were posted as an RMA. Figure 3 is included to depict the configuration of the current posted radiological areas. The borders of these areas are indicated on the map as "Demarcation Lines." The boundaries of the radiologically posted areas and type of posting (e.g., CA, URMA, RMA) are determined based on the guidelines and limits in the RadCon Manual. While radiological demarcation and postings activities are outside the scope of FFACO closure of CAU 366, because the boundaries changed to facilitate closure activities, this information is included and shown in Figure 3. 


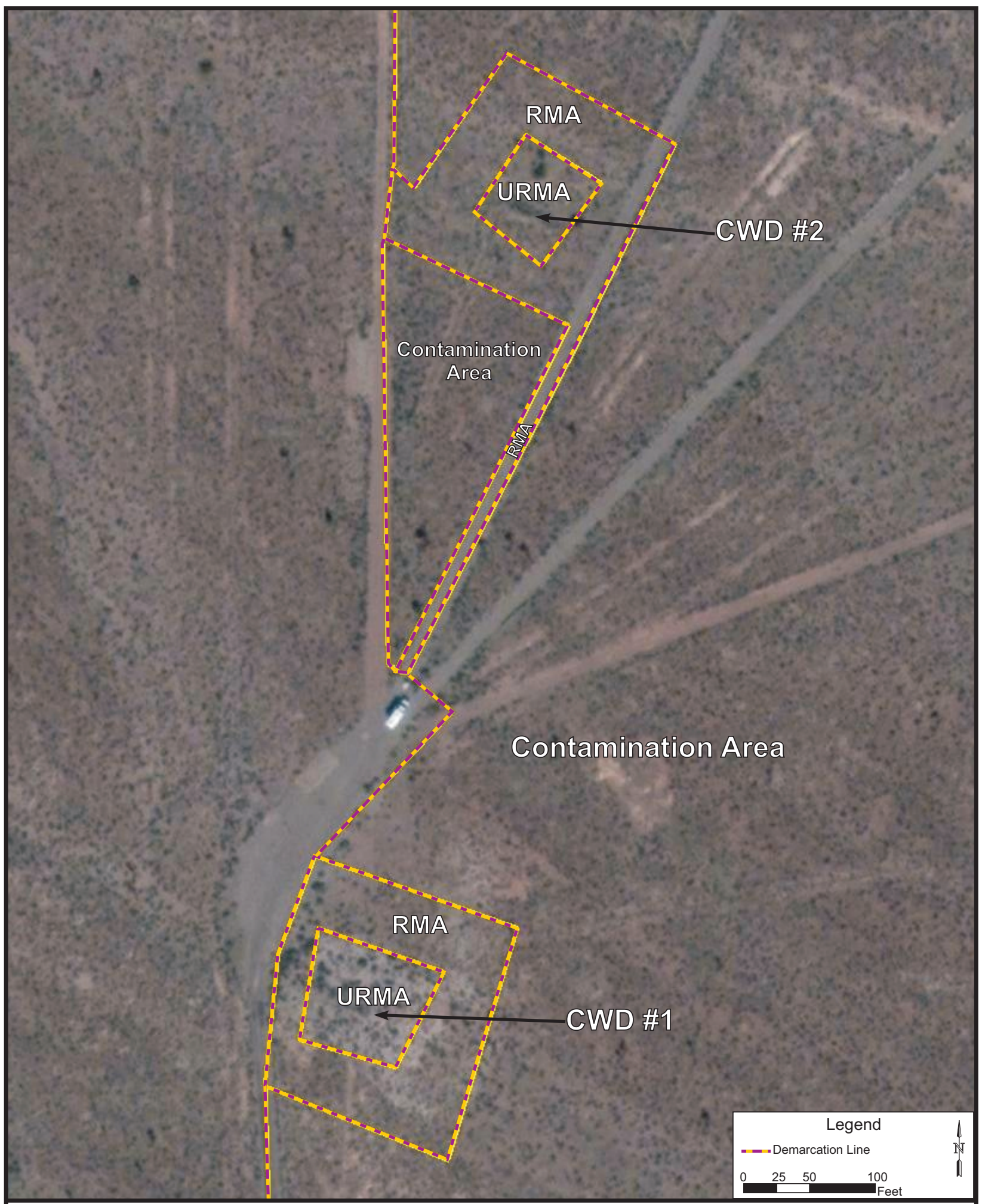

Figure 3. Current Contaminated Waste Dump Radiological Postings 


\subsubsection{Corrective Action Site 11-23-02, Radioactively Contaminated Area B}

This site consists of soil impacted by surface safety experiment Project 56 No. 2, a device containing plutonium and enriched uranium that was detonated with zero yield on November 3, 1955, at Test Area 11b. Test Area 11b is fenced and posted as an HCA. A FFACO UR was implemented for radiological contaminants that are assumed to be present within the HCA associated with Test Area $11 \mathrm{~b}$ at levels exceeding the FAL of $25 \mathrm{mrem} / \mathrm{OU}-\mathrm{yr}$. The UR boundary encompasses the Test Area 11b HCA. In addition, radiologically contaminated debris that exceeds the FAL of $25 \mathrm{mrem} / \mathrm{OU}$-yr is located outside the fence and adjacent to the Test Area 11c HCA. Therefore, the UR boundary was expanded to include the aerial radiological survey isopleth around Test Area $11 \mathrm{~b}$ that corresponds to this isopleth around Test Area 11c in which the contaminated debris is located. Figure 2 shows the UR boundary for CAS 11-23-02. UR warning signs were posted along the existing CA fence that encompasses Plutonium Valley and at the locked gate on the road leading to the site.

\subsubsection{Corrective Action Site 11-23-03, Radioactively Contaminated Area C}

This site consists of soil impacted by surface safety experiment Project 56 No. 3, a device containing plutonium and enriched uranium that was detonated with no yield on November 5, 1955, at Test Area 11c. Test Area 11c is fenced and posted as an HCA. A FFACO UR was implemented for radiological contaminants that are assumed to be present within the HCA associated with Test Area 11c at levels exceeding the FAL of $25 \mathrm{mrem} / \mathrm{OU}-\mathrm{yr}$. The UR boundary encompasses the Test Area 11c HCA. In addition, radiologically contaminated debris that exceeds the FAL of $25 \mathrm{mrem} / \mathrm{OU}$-yr is located outside the fence and adjacent to the Test Area 11c HCA. Therefore, the UR boundary was expanded to include the aerial radiological survey isopleth around Test Area 11c in which the contaminated debris is located. Figure 2 shows the UR boundary for CAS 11-23-03. UR warning signs were posted along the existing CA fence that encompasses Plutonium Valley and at the locked gate on the road leading to the site.

\subsubsection{Corrective Action Site 11-23-04, Radioactively Contaminated Area D}

This site consists of soil impacted by surface safety experiment Project 56 No. 4, a device containing plutonium and enriched uranium that was detonated with a very slight yield on January 18, 1956, at Test Area 11d. Test Area 11d is fenced and posted as an HCA. A FFACO UR was implemented for radiological contaminants that are assumed to be present within the HCA associated with Test Area 11d at levels exceeding the FAL of 25 mrem/OU-yr. The UR boundary encompasses the Test Area 11d HCA. In addition, radiologically contaminated debris that exceeds the FAL of $25 \mathrm{mrem} / \mathrm{OU}$-yr is located outside the fence and adjacent to the Test Area 11c HCA. Therefore, the UR boundary was expanded to include the aerial radiological survey isopleth around Test Area 11d that corresponds to this isopleth around Test Area 11c in which the contaminated debris is located. Figure 2 shows the UR boundary for CAS 11-23-04. UR warning signs were posted along the existing CA fence that encompasses Plutonium Valley and at the locked gate on the road leading to the site. 


\subsubsection{Best Management Practices}

In accordance with Revision 0 of the Soils Risk-Based Corrective Action Evaluation Process (NNSA/NSO, 2012c), an administrative UR was established as a BMP where the total effective dose (TED) exceeds 25 millirems per Industrial Area year (mrem/IA-yr). This limit is based on continuous industrial use of the site and addresses exposure to industrial workers who would regularly be assigned to the work area for an entire career ( 250 days per year, 8 hours per day, for 25 years). The administrative UR will prevent inadvertent exposure of workers to radioactivity if a more intensive use of the site is considered in the future. The boundaries of the areas where the TED exceeds $25 \mathrm{mrem} / \mathrm{IA}-\mathrm{yr}$ are within the existing CA that encompasses Plutonium Valley.

As a precautionary measure, the administrative UR boundary was expanded to also encompass areas where removable contamination is present at levels that require the area to be posted and controlled as a CA. This will further ensure that workers will not perform activities within this area without being notified of the presence of site contaminants. Therefore, the administrative UR boundary was established around the perimeters of the large CA that encompasses the site and the CAs associated with the decontamination station and hot park. The administrative UR does not require postings or inspections. The administrative UR will be recorded in accordance with the FFACO.

The corrective actions for CAU 366 are based on the assumption that activities on the NNSS will be limited to those that are industrial in nature and that the NNSS will maintain controlled access (i.e., restrict public access and residential use). Should the future land use of the NNSS change such that these assumptions are no longer are valid, additional evaluation may be necessary.

\subsection{Deviations From the Corrective ACtion Plan as APPROVED}

Deviations from the CAP for CAU 366 were not required.

\subsection{Corrective ACtion Schedule as Completed}

Closure activities began in January 2013 and were completed in June 2013.

\subsection{Site Plan/Survey Plat}

As-built drawings were not required for CAU 366 closure activities. 


\subsection{WASTE DISPOSITION}

This section describes the waste generated during closure activities and its final disposition.

\subsection{WASTE MANAGEMENT}

Waste was characterized and managed according to federal and state regulations, U.S. Department of Energy orders, and company procedures. Waste management areas (WMAs) were established and identified with appropriate signs and boundaries to restrict unauthorized access. WMAs were inspected as required to ensure that containers were intact, not leaking, and not exceeding storage duration limits. Applicable WMAs were posted as RMAs when radiological waste was stored in the area. Upon removal of radiologically impacted waste, RMAs were surveyed and de-posted.

Waste containers were purchased either new or reconditioned. Containers were inspected prior to use to verify that they were in good condition (e.g., no leaks, rust, or dents), lined or made of material that would not react with the waste, and met U.S. Department of Transportation requirements. Containers remained closed while stored unless waste was being added or removed. Containers were handled in such a manner that the integrity of the container was not compromised. Appropriate labels were affixed, and relevant information was marked on the containers with an indelible marker. Information was legible and clearly visible.

\subsection{WASTE DisPOSAL}

Personal protective equipment (PPE) and housekeeping debris (fence material removed prior to construction of the landfill covers) generated during closure activities was packaged in one intermodal container for disposal as low-level waste (LLW). The total volume of the waste was approximately 52 cubic feet. The LLW was disposed of at the Area 5 Radioactive Waste Management Site (RWMS) on August 7, 2013. No other waste was generated. Waste disposition documentation is included in Appendix B of this report. 
CAU 366 Closure Report

Section: Waste Disposition

Revision: 0

Date: December 2013

THIS PAGE INTENTIONALLY LEFT BLANK 


\subsection{CLOSURE VERIFICATION RESULTS}

Photographs documenting site conditions before and after closure are included in Appendix $\mathrm{C}$ of this report. The soil covers at CWD \#1 and CWD \#2 were verified to be a minimum thickness of $3 \mathrm{ft}$ by comparing final grade elevations to known pre-construction elevations. As-built drawings were not required for the non-engineered soil covers.

\subsection{Data Quality Assessment}

Samples were not collected for closure of CAU 366.

\subsection{USE RESTRICTION}

FFACO URs were implemented for areas where the TED exceeds the FAL of $25 \mathrm{mrem} / \mathrm{OU}-\mathrm{yr}$. The FFACO URs are located within the fenced CA that encompasses Plutonium Valley. No activities except required post-closure inspections and repairs are permitted within the FFACO UR boundaries without prior notification to and approval from the Nevada Division of Environmental Protection (NDEP). The Use Restriction Information form and figures showing the UR boundary for each CAS are included in Appendix D of this report. Post-closure requirements are summarized in Section 5.2.

\subsubsection{Corrective Action Site 11-08-01, Contaminated Waste Dump \#1}

A FFACO UR was implemented for the CWD \#1 soil cover and an adjacent mound containing buried debris. UR warning signs were attached to the concrete monuments located at the corners of the soil cover. The mound is located within the UR warning signs that were posted along the existing three-strand wire CA fence that encompasses Plutonium Valley.

\subsubsection{Corrective Action Site 11-08-02, Contaminated Waste Dump \#2}

A FFACO UR was implemented for the CWD \#2 soil cover. UR warning signs were attached to the concrete monuments located at the corners of the soil cover.

\subsubsection{Corrective Action Site 11-23-02, Radioactively Contaminated Area B}

A FFACO UR was implemented for the Test Area 11b HCA and the aerial radiological survey isopleth around Test Area 11b that corresponds to the isopleth at Test Area 11c in which contaminated debris is located. UR warning signs were posted along the existing three-strand wire CA fence that encompasses Plutonium Valley and at the locked gate on the road leading to the site.

\subsubsection{Corrective Action Site 11-23-03, Radioactively Contaminated Area C}

A FFACO UR was implemented for the Test Area 11c HCA and the aerial radiological survey isopleth around Test Area 11c in which contaminated debris is located. UR warning signs were posted along the existing three-strand wire CA fence that encompasses Plutonium Valley and at the locked gate on the road leading to the site. 


\subsubsection{Corrective Action Site 11-23-04, Radioactively Contaminated Area D}

A FFACO UR was implemented for the Test Area 11d HCA and the aerial radiological survey isopleth around Test Area 11d that corresponds to the isopleth at Test Area 11c in which contaminated debris is located. UR warning signs were posted along the existing three-strand wire CA fence that encompasses Plutonium Valley and at the locked gate on the road leading to the site.

\subsubsection{Administrative Use Restriction}

An administrative UR was implemented as a BMP for the areas where the TED exceeds $25 \mathrm{mrem} / \mathrm{IA}-\mathrm{yr}$ and where removable contamination is present at levels that require the area to be posted and controlled as a CA. The administrative UR boundary was established around the perimeters of the large CA that encompasses the site and the CAs associated with the decontamination station and hot park. The administrative UR is recorded and controlled in the same manner as an FFACO UR but does not require postings or inspections.

The corrective actions for CAU 366 are based on the assumption that activities on the NNSS will be limited to those that are industrial in nature and that the NNSS will maintain controlled access (i.e., restrict public access and residential use). Establishing an administrative UR will prevent inadvertent exposure of workers to radioactivity if a more intensive use of the site were to be considered in the future. Any proposed activity within this area that would change the current land exposure scenario based on a more intensive use of the site would require additional evaluation and NDEP approval. Activities permitted under the current land use without NDEP approval include short duration activities such as site visits, maintenance of UR postings, maintenance of the radiological demarcation fence and postings, road repairs, radiological training activities, soil sampling, radiological surveys, and work on utilities. 


\subsection{CONCLUSIONS AND RECOMMENDATIONS}

Closure activities began in January 2013 and were completed in June 2013. Activities were conducted according to the CAP for CAU 366 (NNSA/NFO, 2013). The corrective actions included no further action and closure in place.

\subsection{CONCLUSIONS}

The following closure activities were performed at CAU 366 as documented in this CR:

- Non-engineered soil covers $3 \mathrm{ft}$ thick were constructed at CAS 11-08-01 over CWD \#1 and at CAS 11-08-02 over CWD \#2. UR warning signs were attached to the concrete monuments located at the corners of the soil covers.

- FFACO URs were implemented for areas where the TED exceeds the FAL of $25 \mathrm{mrem} / \mathrm{OU}-\mathrm{yr}$. The FFACO URs are located within the fenced CA that encompasses Plutonium Valley. UR warning signs were posted along the existing CA fence and at the locked gate on the road leading to the site.

- An administrative UR was implemented as a BMP for the areas where the TED exceeds $25 \mathrm{mrem} / \mathrm{IA}-\mathrm{yr}$ and where removable contamination is present at levels that require the area to be posted and controlled as a CA. The administrative UR boundary was established around the perimeters of the large CA that encompasses the site and the CAs associated with the decontamination station and hot park.

- Closure activities generated LLW, including PPE and housekeeping debris, that was packaged in one intermodal container and disposed of at the Area 5 RWMS.

\subsection{Post-Closure ReQuirements}

Inspections will be performed annually to verify that the UR warning signs are in place and legible and that the UR is maintained. During the annual inspection, the soil covers will be inspected for cracks, animal burrows, and other signs of erosion. Maintenance or repair needs that are identified, such as sign or post repair, fence repair, or soil cover maintenance, will be completed prior to the following inspection and documented in writing at the time the work is done. Inspection results will be documented in the annual combined NNSS post-closure letter report that is submitted to NDEP.

\subsection{RECOMMENDATIONS}

Because closure activities for CAU 366 have been completed following the CAP for CAU 366 (NNSA/NFO, 2013) as documented in this CR, NNSA/NFO requests the following:

- A Notice of Completion from NDEP to NNSA/NFO for closure of CAU 366

- The transfer of CAU 366 from Appendix III to Appendix IV, Closed Corrective Action Units, of the FFACO 
CAU 366 Closure Report

Section: Conclusions and Recommendations

Revision: 0

Date: December 2013

\section{THIS PAGE INTENTIONALLY LEFT BLANK}




\subsection{REFERENCES}

Federal Facility Agreement and Consent Order, 1996 (as amended). Agreed to by the State of Nevada; U.S. Department of Energy, Environmental Management;

U.S. Department of Defense; and U.S. Department of Energy, Legacy Management.

FFACO, see Federal Facility Agreement and Consent Order.

NNSA/NFO, see U.S. Department of Energy, National Nuclear Security Administration Nevada Field Office.

NNSA/NSO, see U.S. Department of Energy, National Nuclear Security Administration Nevada Site Office.

Radiological Control Managers' Council, 2012. Nevada National Security Site Radiological Control Manual, DOE/NV/25946--801 Revision 2. March 2012. Las Vegas, NV.

U.S. Department of Energy, National Nuclear Security Administration Nevada Field Office, 2013. Corrective Action Plan for Corrective Action Unit 366: Area 11 Plutonium Valley Dispersion Sites, Nevada National Security Site, Nevada. DOE/NV--1502. Las Vegas, NV.

U.S. Department of Energy, National Nuclear Security Administration Nevada Site Office, 2011. Corrective Action Investigation Plan for Corrective Action Unit 366: Area 11 Plutonium Valley Dispersion Sites, Nevada National Security Site, Nevada. DOE/NV--1466. Las Vegas, NV.

U.S. Department of Energy, National Nuclear Security Administration Nevada Site Office, 2012a. Corrective Action Decision Document for Corrective Action Unit 366: Area 11 Plutonium Valley Dispersion Sites, Nevada National Security Site, Nevada. DOE/NV--1488. Las Vegas, NV.

U.S. Department of Energy, National Nuclear Security Administration Nevada Site Office, 2012b. Soils Activity Quality Assurance Plan. DOE/NV--1478. Revision 0. Las Vegas, NV.

U.S. Department of Energy, National Nuclear Security Administration Nevada Site Office, 2012c. Soils Risk-Based Corrective Action Evaluation Process. DOE/NV--1475. Revision 0. Las Vegas, NV. 
CAU 366 Closure Report

Section: References

Revision: 0

Date: December 2013

THIS PAGE INTENTIONALLY LEFT BLANK 


\section{APPENDIX A*}

\section{DATA QUALITY OBJECTIVES}

*As presented and published in the approved Corrective Action Investigation Plan for Corrective Action Unit 366: Area 11 Plutonium Valley Dispersion Sites, Nevada National Security Site, Nevada, 2011, DOE/NV--1466. Las Vegas, NV. 
CAU 366 Closure Report

Section: Appendix A

Revision: 0

Date: December 2013

\section{THIS PAGE INTENTIONALLY LEFT BLANK}


The DQO process described in this appendix is a seven-step strategic systematic process used to plan data collection activities and define performance criteria for the CAU 366, Area 11 Plutonium Valley Dispersion Sites, field investigation. The DQOs are designed to ensure that the data collected will provide sufficient and reliable information to identify, evaluate, and technically defend recommended corrective actions (i.e., no further action, closure in place, or clean closure). Existing information about the nature and extent of contamination at the CASs in CAU 366 is insufficient to evaluate and select preferred corrective actions; therefore, a CAI will be conducted.

The CAU 366 CAI will be based on the DQOs presented in this appendix as developed by representatives of the NDEP and the NNSA/NSO. The seven steps of the DQO process presented in Sections A.2.0 through A.8.0 were developed in accordance with Guidance on Systematic Planning Using the Data Quality Objectives Process (EPA, 2006).

The DQO process presents a combination of probabilistic and judgmental sampling approaches. In general, the procedures used in the DQO process provide the following:

- A method to establish performance or acceptance criteria, which serve as the basis for designing a plan for collecting data of sufficient quality and quantity to support the goals of a study.

- Criteria that will be used to establish the final data collection design, such as

- the nature of the problem that has initiated the study and a conceptual model of the environmental hazard to be investigated,

- the decisions or estimates that need to be made, and the order of priority for resolving them,

- the type of data needed, and

- an analytic approach or decision rule that defines the logic for how the data will be used to draw conclusions from the study findings.

- Acceptable quantitative criteria on the quality and quantity of the data to be collected, relative to the ultimate use of the data. 
- A data collection design that will generate data meeting the quantitative and qualitative criteria specified. A data collection design specifies the type, number, location, and physical quantity of samples and data, as well as the QA and QC activities that will ensure that sampling design and measurement errors are managed sufficiently to meet the performance or acceptance criteria specified in the DQOs. 


\section{A.2.0 Step 1 - State the Problem}

Step 1 of the DQO process defines the problem that requires study, identifies the planning team, and develops a conceptual model of the environmental hazard to be investigated.

The problem statement for CAU 366 is as follows: "Existing information on the nature and extent of potential contamination is insufficient to evaluate and recommend CAAs for the CASs in CAU 366."

\section{A.2.1 Planning Team Members}

The DQO planning team consists of representatives from NDEP and NNSA/NSO. The team met on July 6, 2011, for the DQO meeting.

\section{A.2.2 Conceptual Site Model}

The CSM is used to organize and communicate information about site characteristics and serves as the basis of the planning process. It reflects the best interpretation of available information at a point in time. The CSM is a primary vehicle for communicating assumptions about release mechanisms, potential migration pathways, or specific constraints. It provides a summary of how and where contaminants are expected to move and what impacts such movement may have. It is the basis for assessing how contaminants could reach receptors both in the present and future. The CSM describes the most probable scenario for current conditions at each site and defines the assumptions that are the basis for identifying appropriate sampling strategy and data collection methods. An accurate CSM is important as it serves as the basis for all subsequent inputs and decisions throughout the DQO process.

The CSM was developed for CAU 366 using information from the physical setting, potential contaminant sources, release information, historical background information, knowledge from similar sites, and physical and chemical properties of the COPCs and the potentially affected media. 
The CSM consists of the following:

- Potential contaminant releases, including media subsequently affected.

- Release mechanisms (the conditions associated with the release).

- Potential contaminant source characteristics, including contaminants suspected to be present and contaminant-specific properties.

- Site characteristics, including physical, topographical, and meteorological information.

- Migration pathways and transport mechanisms that describe the potential for migration and where the contamination may be transported.

- The locations of points of exposure where individuals or populations may come in contact with a COC associated with a CAS.

- Routes of exposure where contaminants may enter the receptor.

If additional elements are identified during the CAI that are outside the scope of the CSM, the situation will be reviewed and a recommendation will be made as to how to proceed. In such cases, NDEP will be notified and given the opportunity to comment on, or concur with, the recommendation.

The applicability of the CSM to each CAS is summarized in Table A.2-1 and discussed below. Table A.2-1 provides information on CSM elements that will be used throughout the remaining steps of the DQO process. Figure A.2-1 depicts a representation of the conceptual pathways to receptors from CAU 366 sources. Figure A.2-2 depicts a graphical representation of the CSM. 
Table A.2-1

Conceptual Site Model Description of Elements for Each CAS in CAU 366

\begin{tabular}{|c|c|c|c|c|c|c|}
\hline CAS Identifier & $11-08-01$ & $11-08-02$ & $11-23-01$ & $11-23-02$ & $11-23-03$ & $11-23-04$ \\
\hline $\begin{array}{l}\text { CAS } \\
\text { Description }\end{array}$ & $\begin{array}{c}\text { Contaminated } \\
\text { Waste Dump } \\
\# 1\end{array}$ & $\begin{array}{c}\text { Contaminated } \\
\text { Waste Dump } \\
\# 2\end{array}$ & $\begin{array}{c}\text { Radioactively } \\
\text { Contaminated } \\
\text { Area A }\end{array}$ & $\begin{array}{c}\text { Radioactively } \\
\text { Contaminated } \\
\text { Area B }\end{array}$ & $\begin{array}{c}\text { Radioactively } \\
\text { Contaminated } \\
\text { Area C }\end{array}$ & $\begin{array}{c}\text { Radioactively } \\
\text { Contaminated } \\
\text { Area D }\end{array}$ \\
\hline Site Status & \multicolumn{6}{|c|}{ Sites are inactive and/or abandoned } \\
\hline $\begin{array}{l}\text { Exposure } \\
\text { Scenario }\end{array}$ & \multicolumn{6}{|c|}{ Occasional Use Area } \\
\hline $\begin{array}{l}\text { Sources of } \\
\text { Potential Soil } \\
\text { Contamination }\end{array}$ & \multicolumn{2}{|c|}{$\begin{array}{l}\text { Stored and buried } \\
\text { radioactively contaminated } \\
\text { debris (metal, cables, wood), } \\
\text { sand, and soil }\end{array}$} & \multicolumn{4}{|c|}{$\begin{array}{l}\text { Primary Release: Atmospheric deposition of radionuclides } \\
\text { from four safety experiments } \\
\text { Other Releases: Radioactively contaminated debris, effluent from } \\
\text { decontamination/hot park activities, drainages }\end{array}$} \\
\hline $\begin{array}{l}\text { Location of } \\
\text { Contamination/ } \\
\text { Release Point }\end{array}$ & \multicolumn{2}{|c|}{$\begin{array}{l}\text { Surface and subsurface soil } \\
\text { within the CWDs }\end{array}$} & \multicolumn{4}{|c|}{$\begin{array}{l}\text { Surface soil surrounding the four GZ locations; soil directly below or } \\
\text { adjacent to contaminated debris; sediment in washes; and } \\
\text { surface/shallow subsurface soil from decontamination/hot park activities }\end{array}$} \\
\hline $\begin{array}{l}\text { Amount } \\
\text { Released }\end{array}$ & \multicolumn{6}{|c|}{ Unknown } \\
\hline Affected Media & \multicolumn{6}{|c|}{ Surface, shallow, and subsurface soil; wash sediments } \\
\hline $\begin{array}{l}\text { Potential } \\
\text { Contaminants }\end{array}$ & \multicolumn{6}{|c|}{$\begin{array}{l}\text { Isotopic Pu, Isotopic U, Isotopic Am, other potential radionuclides, and fission products; RCRA metals; } \\
\text { VOCs and SVOCs (asphalt near 11c) }\end{array}$} \\
\hline $\begin{array}{l}\text { Transport } \\
\text { Mechanisms }\end{array}$ & \multicolumn{6}{|c|}{$\begin{array}{l}\text { Surface water runoff serves as the major driving force for lateral migration of contaminants while percolation of } \\
\text { precipitation or runoff through subsurface media provides a driver for vertical transport of contaminants. Wind } \\
\text { may cause limited resuspension and transport of windborne contaminants; however, this transport mechanism } \\
\text { is less likely to cause migration of contamination at levels exceeding FALs. }\end{array}$} \\
\hline $\begin{array}{l}\text { Migration } \\
\text { Pathways }\end{array}$ & \multicolumn{6}{|c|}{$\begin{array}{l}\text { Vertical transport is expected to dominate over lateral transport due to small surface gradients. However, the } \\
\text { CASs are located on an alluvial fan that drains to Yucca Flat, so there is some potential for lateral transport. }\end{array}$} \\
\hline $\begin{array}{l}\text { Lateral } \\
\text { and Vertical } \\
\text { Extent of } \\
\text { Contamination }\end{array}$ & \multicolumn{6}{|c|}{$\begin{array}{l}\text { Contamination, if present, is expected to be contiguous to the release points. Concentrations are expected to } \\
\text { decrease with distance and depth from the source. Groundwater contamination is not expected. Lateral and } \\
\text { vertical extent of COC contamination is assumed to be within the spatial boundaries. }\end{array}$} \\
\hline $\begin{array}{l}\text { Exposure } \\
\text { Pathways }\end{array}$ & \multicolumn{6}{|c|}{$\begin{array}{l}\text { The potential for contamination exposure is limited to industrial and construction workers, and military } \\
\text { personnel conducting training. These human receptors may be exposed to COPCs through oral ingestion, } \\
\text { inhalation, and dermal contact (absorption) of soil and/or debris due to inadvertent disturbance of these } \\
\text { materials or direct radiation exposure by radioactive materials. }\end{array}$} \\
\hline
\end{tabular}




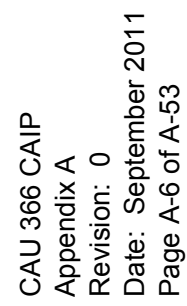

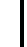
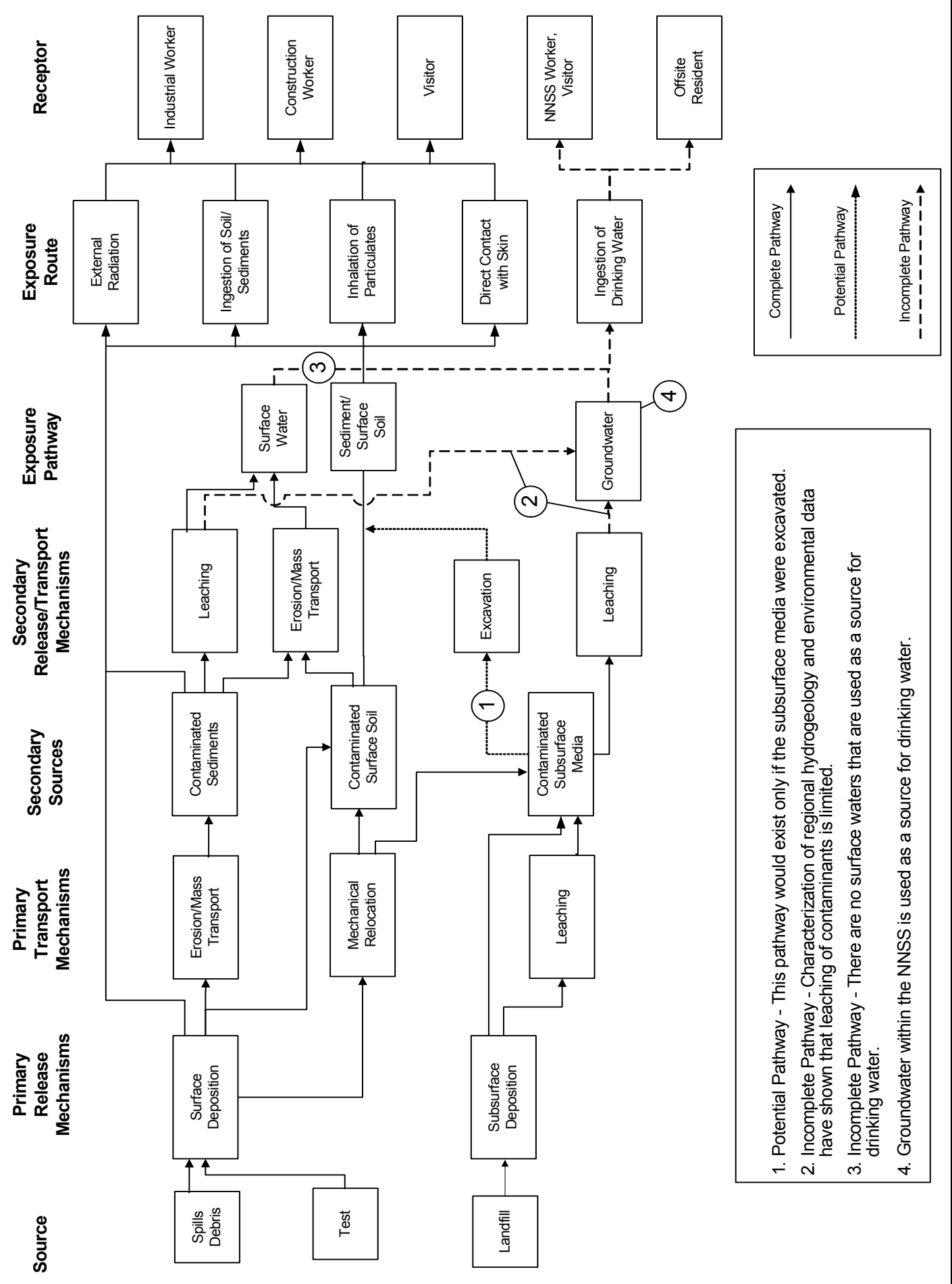

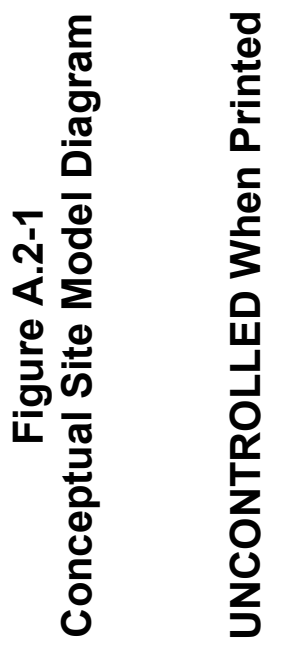



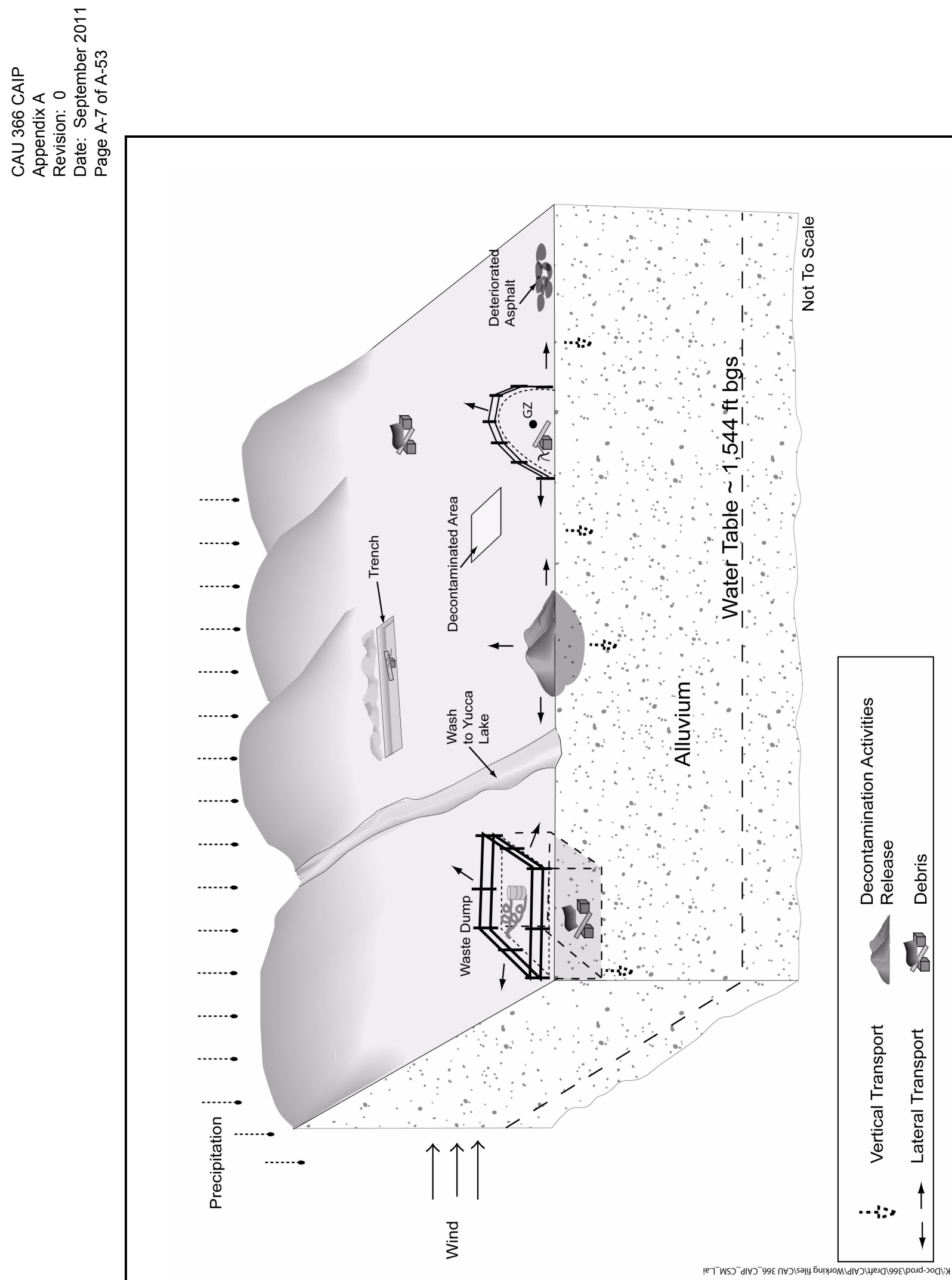

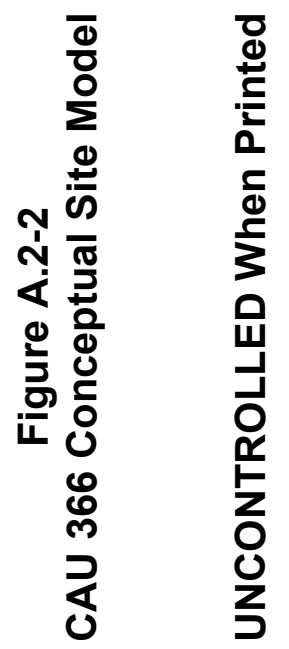




\section{A.2.2.1 Release Sources}

The releases of contamination to CAU 366 are directly or indirectly associated with the four Project 56 safety experiments. The primary release scenario consists of the initial atmospheric deposition of radiological contamination to surface soil and debris present in the area at the time of the experiments. Contamination of the surface soil may be the source for future migration. The following identifies the primary release sources specific to four CASs in CAU 366 (DOE/NV, 2000):

- The Project 56 No. 1 (CAS 11-23-01) source was a surface safety experiment with zero yield that was detonated at location 11a on November 1, 1955. The experiment included the use of a device containing primarily enriched uranium.

- The Project 56 No. 2 (CAS 11-23-02) source was a surface safety experiment with zero yield that was detonated at location $11 \mathrm{~b}$ on November 3,1955 . The experiment included the use of a device containing plutonium and enriched uranium.

- The Project 56 No. 3 (CAS 11-23-03) source was a surface safety experiment with no yield that was detonated at location 11c on November 5, 1955. The experiment included the use of a device containing plutonium and enriched uranium.

- The Project 56 No. 4 (CAS 11-23-04) source was a surface safety experiment with a very slight yield that was detonated at location 11d on January 18, 1956. The experiment included the use of a device containing plutonium and enriched uranium.

Other releases are defined as all other types of releases resulting in soil contamination from spills or wastes found at the site during the investigation, or contaminated materials that have migrated as a result of wind, water, excavation, or some other influence. Corrective Action Sites 11-08-01 and 11-08-02 are waste dumps containing various types of debris (e.g., cable, drums containing contaminated ashed wood and sand, metal scraps) present on the surface and buried in the subsurface. The items were contaminated as a result of the primary release (four safety experiments) but are now considered an other release due to the potential release of contamination to the soil within the boundaries of the waste dumps. A decontamination station and hot park were used to decontaminate personnel and drums or other materials and equipment by using water and soap. The water and any removed contamination was presumably discharged to the surrounding soil. The trench at 11a may contain wastes and debris that could be a source of an other release. Additionally, washes flowing through the CA, particularly the 11d test area, are potential other releases associated with Project 56. 
The most likely locations of the contamination and releases to the environment are the soils directly below or adjacent to the CSM's surface and subsurface components (i.e., soils impacted by fallout and other releases).

\section{A.2.2.2 Potential Contaminants}

The CAS-specific COPCs are based on a conservative evaluation of possible site activities identified during the planning process through the review of site history, process knowledge, personal interviews, past investigation efforts (where available), and inferred activities associated with the CASs. Additional COPCs for other releases may be discovered during the investigation. Specific COPCs (and subsequently the analyses requested) will be determined for other potential releases based on the nature of the potential release (e.g., hydrocarbon stain, lead bricks). The list of COPCs is intended to encompass all of the significant contaminants that could potentially be present at each CAS. Significant contaminants are defined as contaminants that are present at concentrations exceeding the PAL. The COPCs applicable to Decision I environmental samples from each of the CASs of CAU 366 are listed in Table A.2-2. Table A.2-3 lists the analyses required for these COPCs while Table A.2-4 lists all the analytes that are reported for those analyses.

Table A.2-2

Contaminants of Potential Concern ${ }^{a}$

(Page 1 of 2)

\begin{tabular}{|c|c|c|c|}
\hline cOPCs & $\begin{array}{l}\text { CASs 11-08-01 } \\
\text { and 11-08-02 }\end{array}$ & $\begin{array}{c}\text { CAS } \\
11-23-01\end{array}$ & $\begin{array}{c}\text { CASs 11-23-02, } \\
11-23-03,11-23-04\end{array}$ \\
\hline \multicolumn{4}{|c|}{ Organic COPCs } \\
\hline 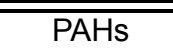 & $=$ & $\overline{--}$ & $\overline{X^{6}}$ \\
\hline \multicolumn{4}{|c|}{ Inorganic COPCs } \\
\hline Lead & ב-- & $\overline{-1-}$ & $\bar{x}$ \\
\hline \multicolumn{4}{|c|}{ Radionuclide COPCs } \\
\hline $\bar{U}-234$ & $\bar{X}$ & $\bar{x}$ & $\bar{x}$ \\
\hline U-235/236 & $\bar{x}$ & $\bar{x}$ & $x$ \\
\hline $\mathrm{U}-238$ & $x$ & $\bar{x}$ & $\bar{x}$ \\
\hline Pu-238 & $\bar{x}$ & $\bar{x}$ & $\mathrm{x}$ \\
\hline Pu-239/240 & $x$ & $x$ & $x$ \\
\hline
\end{tabular}


Table A.2-2

\section{Contaminants of Potential Concern ${ }^{\mathrm{a}}$}

(Page 2 of 2)

\begin{tabular}{|c|c|c|c|}
\hline COPCs & $\begin{array}{c}\text { CASs 11-08-01 } \\
\text { and 11-08-02 }\end{array}$ & $\begin{array}{c}\text { CAS } \\
\text { 11-23-01 }\end{array}$ & $\begin{array}{c}\text { CASs 11-23-02, } \\
\text { 11-23-03, 11-23-04 }\end{array}$ \\
\hline \hline $\mathrm{Cs}-137$ & $\mathrm{X}$ & $\mathrm{X}$ & $\mathrm{X}$ \\
\hline $\mathrm{Am}-241$ & $\mathrm{X}$ & $\mathrm{X}$ & $\mathrm{X}$ \\
\hline
\end{tabular}

${ }^{a}$ The COPCs are the constituents that, based on process knowledge and historical documentation, are likely to be present.

${ }^{\mathrm{b}}$ Analyses for PAHs will only be run on the sample plot in the asphalt area.

Table A.2-3

Analytical Method ${ }^{a}$

\begin{tabular}{|c|c|c|c|}
\hline Analyses & $\begin{array}{c}\text { CASs 11-08-01 } \\
\text { and 11-08-02 }\end{array}$ & $\begin{array}{c}\text { CAS } \\
11-23-01\end{array}$ & $\begin{array}{c}\text { CASs 11-23-02, } \\
11-23-03,11-23-04\end{array}$ \\
\hline \multicolumn{4}{|c|}{ Organic COPCs } \\
\hline SVOCs & $\overline{---}$ & $\overline{---}$ & $\mathrm{X}^{\mathrm{b}}$ \\
\hline VOCs & -- & -- & $\mathrm{X}^{\mathrm{b}}$ \\
\hline \multicolumn{4}{|c|}{ Inorganic COPCs } \\
\hline RCRA Metals & -- & -- & $\mathrm{X}$ \\
\hline \multicolumn{4}{|c|}{ Radionuclide COPCs } \\
\hline Gamma Spectroscopy $^{b}$ & $\bar{X}$ & $\bar{x}$ & $\bar{x}$ \\
\hline Isotopic U & $\mathrm{X}$ & $x$ & $\mathrm{X}$ \\
\hline Isotopic $\mathrm{Pu}$ & $x$ & $x$ & $\mathrm{X}$ \\
\hline
\end{tabular}

aThe analytical method has been determined based on the site specific COPCs.

${ }^{b}$ Analyses for SVOCs and VOCs will only be run on the sample plot in the asphalt area.

$X=$ Analytical method required for this CAS

-- = Analytical method not required for this CAS

\section{A.2.2.3 Contaminant Characteristics}

Contaminant characteristics include, but are not limited to, solubility, density, and adsorption potential. In general, contaminants with low solubility, high affinity for media, and high density can be expected to be found relatively close to release points. Contaminants with small particle size, high solubility, low density, and/or low affinity for media are found further from release points or in low areas where evaporation of ponding will concentrate dissolved contaminants. 
Table A.2-4

Analytes Reported for Required Analyses

\begin{tabular}{|c|c|c|c|c|c|}
\hline \multicolumn{2}{|c|}{ VOCs } & \multicolumn{2}{|c|}{ SVOCs } & Metals & Radionuclides \\
\hline $\begin{array}{l}\text { 1,1,1,2-Tetrachloroethane } \\
\text { 1,1,1-Trichloroethane } \\
\text { 1,1,2,2-Tetrachloroethane } \\
\text { 1,1,2-Trichloroethane } \\
\text { 1,1-Dichloroethane } \\
\text { 1,1-Dichloroethene } \\
\text { 1,2,4-Trichlorobenzene } \\
\text { 1,2,4-Trimethylbenzene } \\
\text { 1,2-Dibromo-3-chloropropane } \\
\text { 1,2-Dichlorobenzene } \\
\text { 1,2-Dichloroethane } \\
\text { 1,2-Dichloropropane } \\
\text { 1,3,5-Trimethylbenzene } \\
\text { 1,3-Dichlorobenzene } \\
\text { 1,4-Dichlorobenzene } \\
\text { 1,4-Dioxane } \\
\text { 2-Butanone } \\
\text { 2-Chlorotoluene } \\
\text { 2-Hexanone } \\
\text { 4-Isopropyltoluene } \\
\text { 4-Methyl-2-pentanone } \\
\text { Acetone } \\
\text { Acetonitrile } \\
\text { Allyl chloride } \\
\text { Benzene } \\
\text { Bromodichloromethane } \\
\text { Bromoform } \\
\text { Bromomethane } \\
\text { Carbon disulfide }\end{array}$ & $\begin{array}{l}\text { Carbon tetrachloride } \\
\text { Chlorobenzene } \\
\text { Chloroethane } \\
\text { Chloroform } \\
\text { Chloromethane } \\
\text { Chloroprene } \\
\text { cis-1,2-Dichloroethene } \\
\text { Dibromochloromethane } \\
\text { Dichlorodifluoromethane } \\
\text { Ethyl methacrylate } \\
\text { Ethylbenzene } \\
\text { Isobutyl alcohol } \\
\text { Isopropylbenzene } \\
\text { Methacrylonitrile } \\
\text { Methyl methacrylate } \\
\text { Methylene chloride } \\
\text { n-Butylbenzene } \\
\text { n-Propylbenzene } \\
\text { sec-Butylbenzene } \\
\text { Styrene } \\
\text { tert-Butylbenzene } \\
\text { Tetrachloroethene } \\
\text { Toluene } \\
\text { Total xylenes } \\
\text { Trichloroethene } \\
\text { Trichlorofluoromethane } \\
\text { Vinyl acetate } \\
\text { Vinyl chloride }\end{array}$ & $\begin{array}{l}\text { 2,3,4,6-Tetrachlorophenol } \\
\text { 2,4,5-Trichlorophenol } \\
\text { 2,4,6-Trichlorophenol } \\
\text { 2,4-Dimethylphenol } \\
\text { 2,4-Dinitrotoluene } \\
\text { 2-Chlorophenol } \\
\text { 2-Methylnaphthalene } \\
\text { 2-Methylphenol } \\
\text { 2-Nitrophenol } \\
\text { 3-Methylphenol }{ }^{\text {a }} \text { (m-cresol) } \\
\text { 4-Methylphenol } \text { (p-cresol) }^{\text {4-Chloroaniline }} \\
\text { 4-Nitrophenol } \\
\text { Acenaphthene } \\
\text { Acenaphthylene } \\
\text { Aniline } \\
\text { Anthracene } \\
\text { Benzo(a)anthracene } \\
\text { Benzo(a)pyrene } \\
\text { Benzo(b)fluoranthene } \\
\text { Benzo(g,h,i)perylene } \\
\text { Benzo(k)fluoranthene } \\
\text { Benzoic acid } \\
\text { Benzyl alcohol } \\
\text { Bis(2-ethylhexyl)phthalate } \\
\text { Butyl benzyl phthalate } \\
\text { Carbazole } \\
\text { Chrysene } \\
\text { Di-n-butyl phthalate } \\
\end{array}$ & $\begin{array}{l}\text { Di-n-octyl phthalate } \\
\text { Dibenzo(a,h)anthracene } \\
\text { Dibenzofuran } \\
\text { Diethyl phthalate } \\
\text { Dimethyl phthalate } \\
\text { Fluoranthene } \\
\text { Fluorene } \\
\text { Hexachlorobenzene } \\
\text { Hexachlorobutadiene } \\
\text { Hexachloroethane } \\
\text { Indeno(1,2,3-cd)pyrene } \\
\text { n-Nitroso-di-n-propylamine } \\
\text { Naphthalene } \\
\text { Nitrobenzene } \\
\text { Pentachlorophenol } \\
\text { Phenanthrene } \\
\text { Phenol } \\
\text { Pyrene } \\
\text { Pyridine }\end{array}$ & \begin{tabular}{|l} 
Arsenic \\
Barium \\
Beryllium \\
Cadmium \\
Chromium \\
Lead \\
Mercury \\
Selenium \\
Silver
\end{tabular} & $\begin{array}{l}\text { Gross Alpha/Beta } \\
\text { Pu-238 } \\
\text { Pu-239/240 } \\
\text { U-234 } \\
\text { U-235 } \\
\text { U-238 } \\
\text { Gamma-Emitting } \\
\text { Ac-228 } \\
\text { Am-241 } \\
\text { Co-60 } \\
\text { Cs-137 } \\
\text { Eu-152 } \\
\text { Eu-154 } \\
\text { Eu-155 } \\
\text { Nb-94 } \\
\text { Th-234 } \\
\text { U-235 }\end{array}$ \\
\hline
\end{tabular}

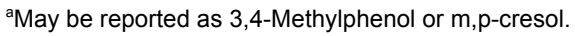

$A c=$ Actinium

As stated in the document Subsurface Nobel Gas Transport at the Nevada Test Site (Thompson et al., 1997), the Cambric test at the NTS was used to study long-term radionuclide migration from the underground detonation of a nuclear device. The Cambric test (with a yield of 750 tons) was conducted below the water table in Frenchman Flat in 1965. A well installed into the groundwater $91 \mathrm{~m}$ away from GZ was continuously pumped from 1975 to 1991 in order to draw radionuclides from the detonation cavity. The extracted water was tested for radionuclides. None of the adsorbing radionuclides (Am-241, calcium [Ca]-41, Cs-137, Eu-154, Pu-241, samarium [Sm]-151, neptunium [Np]-237, and Sr-90) were detected in the pumped groundwater (attesting to their low solubility and affinity to adsorb to media). The radionuclides tritium and krypton detected in the pumped groundwater are considered to be conservative tracers in groundwater (i.e., they do not interact with the geologic media through which the water moves). This test demonstrated the relative immobility of the adsorbing radionuclides under saturated conditions. As the mass flow of water is the 
predominant driver in contaminant migration, these adsorbing radionuclides can be expected to be even less mobile in the vadose zone as water movement through the vadose zone is much less than in the saturated conditions of the aquifer.

Based on this evidence, the target radionuclide elements (plutonium and uranium) are classified as adsorbing radionuclides with low solubilities that are located within unsaturated media. Therefore, these contaminants are expected to be found relatively close to release points.

\section{A.2.2.4 Site Characteristics}

Site characteristics are defined by the interaction of physical, topographical, and meteorological attributes and properties. Topographical and meteorological properties and attributes include slope stability, precipitation frequency and amounts, precipitation runoff pathways, drainage channels and ephemeral streams, and evapotranspiration potential. Meteorological data are presented in Section 2.1 .

All six CASs in CAU 366 are located in Area 11 of the NNSS in Yucca Flat. Erosion of the surrounding mountains has resulted in the accumulation of alluvial deposits. The soil in and around the CASs is made up of sandy silt to cobble-sized alluvium of various lithologies. The area is moderately vegetated with native plants. The area is generally flat, but slopes gently toward the west. Prominent washes flow through the test areas (especially 11d) and deposit into a detention basin that ultimately flows toward Yucca Lake. The nearest groundwater well to the CASs is ER-6-1-2 main located approximately $1.8 \mathrm{mi}$ west of test area $11 \mathrm{a}$ and $2.3 \mathrm{mi}$ northwest of test area $11 \mathrm{~d}$. The most recent recorded depth to the water table is approximately $1,544 \mathrm{ft}$ bgs (USGS/DOE, 2011).

\section{A.2.2.5 Migration Pathways and Transport Mechanisms}

Migration pathways include the lateral migration of potential contaminants across surface soils/sediments and vertical migration of potential contaminants through subsurface soils. Contaminants present in ephemeral washes are subject to much higher transport rates than contaminants present in other surface areas. These ephemeral washes are generally dry but are subject to infrequent stormwater flows. These stormwater flow events provide an intermittent mechanism for both vertical and horizontal transport of contaminants. Contaminated sediments 
entrained by these stormwater events would be carried by the streamflow to locations where the flowing water loses energy and the sediments drop out. These locations are readily identifiable as sedimentation accumulation areas. Several washes flow through the area where these CASs are located. The washes flow to a detention basin and ultimately toward Yucca Lake. Contaminants from the sites may also migrate via windborne material, or move through mechanical disturbance due to the decontamination activities and movement of contaminated material to the hot park location and waste dumps.

Migration is influenced by the chemical characteristics of the contaminants (presented in Section A.2.2.3) and the physical characteristics of the vadose material (presented in Section A.2.2.4). In general, the contaminants that are reasonably expected to be present at CAU 366 (i.e., plutonium and uranium) have low solubilities and high affinity for media. The physical characteristics of the vadose material generally include medium and high adsorbive capacities, low moisture contents (i.e., available water-holding capacity), and relatively long distances to groundwater (e.g., 1,544 ft). Based on these physical and chemical factors, contamination is expected to be found relatively close to release points.

Infiltration and percolation of precipitation serve as a driving force for downward migration of contaminants. However, due to high PET (annual PET at the Area 3 RWMS has been estimated at 61.7 in.) and limited precipitation for this region (6.61 in. [ARL/SORD, 2011]), percolation of infiltrated precipitation at the NNSS does not provide a significant mechanism for vertical migration of contaminants to groundwater (DOE/NV, 1992).

Subsurface migration pathways at CAU 366 are expected to be predominately vertical, although spills or leaks at the ground surface may also have limited lateral migration before infiltration. The depth of infiltration (shape of the subsurface contaminant plume) will be dependent upon the type, volume, and duration of the discharge as well as the presence of relatively impermeable layers that could modify vertical or horizontal transport pathways, both on the ground surface (e.g., concrete) and in the subsurface (e.g., caliche layers). 


\section{A.2.2.6 Exposure Scenarios}

Human receptors may be exposed to COPCs through oral ingestion, inhalation, dermal contact (absorption) of soil or debris due to inadvertent disturbance of these materials or external irradiation by radioactive materials. The land-use for CAU 366 is "Nuclear Test Zone," which means the area is reserved for dynamic experiments, hydrodynamic tests, and underground nuclear weapons and weapons effects tests. This zone includes compatible defense and nondefense research, development, and testing activities. The exposure scenario for CAU 366 is "Occasional Use Area." These CASs are in a remote location without any site improvements and where no regular work is performed. There is still the possibility, however, that site workers could occupy these locations on an occasional and temporary basis (up to 80 hours per year for five years) such as a military exercise. Therefore, these sites are classified as an Occasional Use Area. 


\section{A.3.0 Step 2 - Identify the Goal of the Study}

Step 2 of the DQO process states how environmental data will be used in meeting objectives and solving the problem, identifies study questions or decision statement(s), and considers alternative outcomes or actions that can occur upon answering the question(s).

\section{A.3.1 Decision Statements}

The Decision I statement is as follows: "Is any COC present in environmental media within the CAS?" For judgmental sampling design, any analytical result for a COPC above the FAL will result in that COPC being designated as a COC. For probabilistic (unbiased) sampling design, any COPC that has a 95 percent UCL of the average concentration above the FAL will result in that COPC being designated as a COC. A COC may also be defined as a contaminant that, in combination with other like contaminants, is determined to jointly pose an unacceptable risk based on a multiple contaminant analysis (NNSA/NSO, 2006). If a COC is detected, then Decision II must be resolved.

The Decision II statement is as follows: "If a COC is present, is sufficient information available to evaluate potential CAAs?" Sufficient information is defined to include the following:

- The lateral and vertical extent of COC contamination

- The information needed to predict potential remediation waste types and volumes

- The information needed to evaluate the potential for COC migration

A corrective action will be determined for any site containing a COC.

For the primary release scenario, the DQO process resulted in an assumption that TED within the radiologically posted HCAs exceeds the FAL and requires corrective action. Therefore, a default contamination boundary will be established for each HCA (Section 3.4). Figure 3-4 shows the default contamination boundaries for CASs 11-23-02, 11-23-03, and 11-23-04.

For the other release scenario at CASs 11-08-01 and 11-08-02, the DQO process resulted in an assumption that TED within the radiologically posted fence lines of both CWDs exceeds the FAL and requires corrective action. Therefore, a default contamination boundary will be established for each 
CWD (Section 3.4). Figure 3-4 shows the default contamination boundaries for CASs 11-08-01 and 11-08-02.

Decision I samples will be submitted to analytical laboratories to determine the presence of COCs. Decision II samples for both primary and other release scenarios will be submitted to define the extent of unbounded COCs. In addition, samples will be submitted for analyses, as needed, to support waste management or health and safety decisions.

A corrective action may also be required if a waste present within a CAS contains contaminants that, if released, could cause the surrounding environmental media to contain a COC. Such a waste would be considered PSM. To evaluate wastes for the potential to result in the introduction of a COC to the surrounding environmental media, the conservative assumption was made that any physical waste containment would fail at some point and the contaminants would be released to the surrounding media. The following will be used as the criteria for determining whether a waste is PSM:

- A waste, regardless of concentration or configuration, may be assumed to be PSM and handled under a corrective action.

- Based on process knowledge and/or professional judgment, some waste may be assumed to not be PSM if it is clear that it could not result in soil contamination exceeding a FAL.

- If assumptions about the waste cannot be made, then the waste material will be sampled, and the results will be compared to FALs based on the following criteria:

- For non-liquid wastes, the concentration of any chemical contaminant in soil (after degradation of the waste and release of contaminants into soil) would be equal to the mass of the contaminant in the waste divided by the mass of the waste. If the resulting soil concentration exceeds the FAL, then the waste would be considered to be PSM.

- For non-liquid wastes, the dose resulting from radioactive contaminants in soil (after degradation of the waste and release of contaminants into soil) would be calculated using the activity of the contaminant in the waste divided by the mass of the waste (for each radioactive contaminant) and calculating the combined resulting dose using the RESRAD code (Murphy, 2004). If the resulting soil concentration exceeds the FAL, then the waste would be considered to be PSM.

- For liquid wastes, the resulting concentration of contaminants in the surrounding soil will be calculated based on the concentration of contaminants in the waste and the liquid holding capacity of the soil. If the resulting soil concentration exceeds the FAL, then the liquid waste would be considered to be PSM. 
The radiation surveys conducted at CAU 366 identified anomalous radiation values associated with discrete debris items. If these items provided a potential to cause a receptor to receive a dose exceeding the FAL, they would be considered to be PSM. To evaluate the TED associated with these items (and determine whether these items could be PSM), TED will be calculated for two locations of maximum radiation survey values. This will be accomplished at each location by measuring external dose using a TLD and internal dose using a portable low volume air sampler to collect airborne radioactive particles that could be inhaled or ingested. A net TED value will be calculated by subtracting background radiation and TED from soil in the surrounding area. The resulting TED values from these two locations should provide the maximum TED from any debris item at CAU 366. If the resulting TED values are less than the FAL, it will be determined that debris items do not require corrective action. If the resulting TED values exceed the FAL, it will be determined that debris items require corrective action, and an additional radiation survey will be conducted to identify additional debris items that meet this criterion of PSM.

A COC may also be defined as a contaminant that, in combination with other like contaminants, is determined to jointly pose an unacceptable risk (NNSA/NSO, 2006).

If sufficient information is not available to evaluate potential CAAs, then site conditions will be reevaluated and additional samples will be collected (as long as the scope of the investigation is not exceeded and any CSM assumption has not been shown to be incorrect).

\section{A.3.2 Alternative Actions to the Decisions}

This section identifies actions that may be taken to solve the problem depending on the possible outcomes of the investigation.

\section{A.3.2.1 Alternative Actions to Decision I}

If no COC associated with a release from the CAS is detected, then further assessment of the CAS is not required. If a COC associated with a release from the CAS is detected, then the extent of COC contamination will be determined, and additional information required to evaluate potential CAAs will be collected. 


\section{A.3.2.2 Alternative Actions to Decision II}

If the lateral and vertical extent of COC contamination has not been defined by bounding sample results, then additional bounding samples will be collected. If sample analytical results are not sufficient to predict potential remediation waste types, then additional waste characterization samples will be collected. If available information is not sufficient to evaluate the potential for COC migration, additional information will be collected. If sufficient information is not available to evaluate potential CAAs, then additional samples will be collected. Otherwise, collection of additional information is not required. 


\section{A.4.0 Step 3 - Identify Information Inputs}

Step 3 of the DQO process identifies the information needed, determines sources for information, and identifies sampling and analysis methods that will allow reliable comparisons with FALs.

\section{A.4.1 Information Needs}

Decision I has been resolved for the areas inside the default contamination boundaries as these areas have already been identified as requiring corrective action. Therefore, Decision I sampling only applies to those areas outside the default contamination boundaries. To resolve Decision I (determine whether a COC is present at a CAS), samples will be collected and analyzed following these two criteria:

- Samples must either (a) be collected in areas most likely to contain a COC (judgmental sampling) or (b) properly represent contamination at the CAS (probabilistic sampling).

- The analytical suite selected must be sufficient to identify any COCs present in the samples.

Decision II for the primary release contamination within the HCAs has been established as the existing fence line which serves as the default contamination boundary. To resolve Decision II for primary release contamination outside the default contamination boundaries, TED rates need to be established at locations that bound the FAL dose rate and provide sufficient information to establish a high (greater than 0.8) correlation to radiation survey isopleths. A boundary will then be determined around the radiation survey isopleth that correlates to the $25-\mathrm{mrem} / \mathrm{yr}$ FAL.

Decision II for the two CWDs is a geophysical survey to determine whether all buried material is captured within the existing fence line that serves as the default contamination boundary. To resolve Decision II for other release contamination (determine whether sufficient information is available to evaluate potential CAAs at each CAS), samples need to be collected and analyzed to meet the following criteria:

- Samples must be collected in areas contiguous to the contamination but where contaminant concentrations are below FALs. 
- Samples of the waste or environmental media must provide sufficient information to determine potential remediation waste types.

- Samples of the waste must provide sufficient information to determine whether they contain PSM.

- The analytical suites selected must be sufficient to detect contaminants at concentrations equal to or less than their corresponding FALs.

\section{A.4.2 Sources of Information}

Information to satisfy Decision I and Decision II will be generated by collecting environmental samples. These samples will be submitted to analytical laboratories meeting the quality criteria stipulated in the Industrial Sites QAPP (NNSA/NV, 2002a). The TLDs will be submitted to the Environmental Technical Services group at the NNSS, which is certified by the DOE Laboratory Accreditation Program for dosimetry. Only validated data from analytical laboratories will be used to make DQO decisions. Sample collection and handling activities will follow standard procedures.

\section{A.4.2.1 Sample Locations}

Design of the sampling approaches for the CAU 366 CASs must ensure that the data collected are sufficient for selection of the CAAs (EPA, 2002b). To meet this objective, the samples collected from each site should either be from locations that most likely contain a COC, if present (judgmental), or from locations that properly represent overall contamination at the CAS (probabilistic). These sample locations, therefore, can be selected by means of either (a) biasing factors used in judgmental sampling (e.g., debris or location of elevated radioactivity) or (b) randomly using a probabilistic sampling design. The implementation of a judgmental approach for sample location selection, and of a probabilistic sampling approach, for CAU 366 are discussed in Section A.8.0.

\section{A.4.2.2 Analytical Methods}

Analytical methods are available to provide the data needed to resolve the decision statements. The analytical methods and laboratory requirements (e.g., detection limits, precision, and accuracy) for soil samples are provided in Tables 3-2 and 3-3. 


\section{A.5.0 Step 4 - Define the Boundaries of the Study}

Step 4 of the DQO process defines the target population of interest and its relevant spatial boundaries, specifies temporal and other practical constraints associated with sample/data collection, and defines the sampling units on which decisions or estimates will be made.

\section{A.5.1 Target Populations of Interest}

The population of interest to resolve Decision I ("Is any COC present in environmental media within the CAS?") is any location or area within the site that contains contaminant concentrations exceeding a FAL. The populations of interest to resolve Decision II ("If a COC is present, is sufficient information available to evaluate potential CAAs?") are as follows:

- For the primary releases - locations where TED varies from above the FAL to below the FAL

- For the other releases - each one of a set of locations bounding contamination in lateral and vertical directions

- Investigation waste and potential remediation waste

\section{A.5.2 Spatial Boundaries}

Spatial boundaries are the maximum lateral and vertical extent of expected contamination that can be supported by the CSM. Decision II spatial boundaries are as follows:

- Vertical: Primary release - $5 \mathrm{~cm}$ below original ground surface

- Vertical: Other release - $15 \mathrm{ft}$ bgs

- Horizontal: Primary and other release - $4 \mathrm{mi}$ from GZ

Contamination found beyond these boundaries may indicate a flaw in the CSM and may require reevaluation of the CSM before the investigation can continue. Each CAS is considered geographically independent, and intrusive activities are not intended to extend into the boundaries of neighboring CASs.

\section{A.5.3 Practical Constraints}

There are no practical constraints identified for this CAU. 


\section{A.5.4 Define the Sampling Units}

The scale of decision making in Decision I is defined as the individual CAS. Any COC detected at any location within the CAS will cause the determination that the CAS or area is contaminated and needs further evaluation. The scale of decision making for Decision II is defined as a contiguous area contaminated with any COC. Resolution of Decision II requires this contiguous area to be bounded laterally and vertically. 


\section{A.6.0 Step 5 - Develop the Analytic Approach}

Step 5 of the DQO process specifies appropriate population parameters for making decisions, defines action levels, and generates an "If ... then ... else" decision rule that involves it.

\section{A.6.1 Population Parameters}

Population parameters are defined for judgmental and probablistic sampling designs in the following sections. Population parameters are the parameters compared to action levels.

\section{A.6.1.1 Judgmental Sampling Design}

For judgmental sampling results, the population parameter is the observed concentration of each contaminant from each individual analytical sample. Each sample result will be compared to the FALs to determine the appropriate resolution to Decision I and Decision II. A single sample result for any contaminant exceeding a FAL would cause a determination that a COC is present within the CAS (for Decision I), or that the COC is not bounded (for Decision II).

\section{A.6.1.2 Probabilistic Sampling Design}

For probabilistic sampling results, the population parameter is the true TED over the area of the sample plot. Resolution of DQO decisions associated with the probabilistic sampling design requires determining, with a specified degree of confidence, whether the true TED at the site in question exceeds the FAL. Because a calculated TED is an estimate of the true (unknown) TED, it is uncertain how well the calculated TED represents the true TED. If the calculated TED were significantly different than the true TED, a decision based on the calculated TED could result in a decision error. To reduce the probability of making a false negative decision error, a conservative estimate of the true TED is used to compare to the FAL instead of the calculated TED. This conservative estimate (overestimation) of the true TED will be calculated as the 95 percent UCL of the average TED values. By definition, there will be a 95 percent probability that the true TED is less than the 95 percent UCL of the calculated TED.

The computation of appropriate UCLs depends upon the data distribution, the number of samples, the variability of the dataset, and the skewness associated with the dataset. A statistical package will be 
used to determine the appropriate probability distribution (e.g., normal, lognormal, gamma) and/or a suitable non-parametric distribution-free method and then to compute appropriate UCLs. To ensure that the appropriate UCL computational method is used, the sample data will be tested for goodness-of-fit to all of the parametric and non-parametric UCL computation methods described in Calculating the Upper Confidence Limits for Exposure Point Concentrations at Hazardous Waste Sites (EPA, 2002a).

Computation of an appropriate UCL for each of the calculated TED averages requires the following:

- A minimum number of samples are collected.

- The data originate from a symmetric, but not necessarily normally distributed, population.

- The estimation of the variability is reasonable and representative of the population being sampled.

- The population values are not spatially correlated.

\section{A.6.2 Action Levels}

The PALs presented in this section are to be used for site screening purposes. They are not necessarily intended to be used as cleanup action levels or FALs. However, they are useful in screening out contaminants that are not present in sufficient concentrations to warrant further evaluation and, therefore, streamline the consideration of remedial alternatives. The RBCA process used to establish FALs is described in the Industrial Sites Project Establishment of Final Action Levels (NNSA/NSO, 2006). This process conforms with NAC Section 445A.227, which lists the requirements for sites with soil contamination (NAC, 2008a). For the evaluation of corrective actions, NAC Section 445A.22705 (NAC, 2008b) requires the use of ASTM Method E1739 (ASTM, 1995) to "conduct an evaluation of the site, based on the risk it poses to public health and the environment, to determine the necessary remediation standards (i.e., FALs) or to establish that corrective action is not necessary." 
This RBCA process defines three tiers (or levels) of evaluation involving increasingly sophisticated analyses:

- Tier 1 evaluation - Sample results from source areas (highest concentrations) are compared to action levels based on generic (non-site-specific) conditions (i.e., the PALs established in the CAIP). The FALs may then be established as the Tier 1 action levels, or the FALs may be calculated using a Tier 2 evaluation.

- Tier 2 evaluation - Conducted by calculating Tier 2 SSTLs using site-specific information as inputs to the same or similar methodology used to calculate Tier 1 action levels. The Tier 2 SSTLs are then compared to individual sample results from reasonable points of exposure (as opposed to the source areas as is done in Tier 1) on a point-by-point basis. Total TPH concentrations will not be used for risk-based decisions under Tier 2 or Tier 3 . Rather, the individual chemicals of concern will be compared to the SSTLs.

- Tier 3 evaluation - Conducted by calculating Tier 3 SSTLs on the basis of more sophisticated risk analyses using methodologies described in Method E1739 that consider site-, pathway-, and receptor-specific parameters.

The comparison of laboratory results to FALs and the evaluation of potential corrective actions will be included in the investigation report. The FALs will be defined (along with the basis for their definition) in the investigation report.

\section{A.6.2.1 Chemical PALs}

Except as noted herein, the chemical PALs are defined as the Pacific Southwest, Region 9: Regional Screening Levels (Formerly PRGs), Screening Levels for Chemical Contaminants in industrial soils (EPA, 2011). Background concentrations for RCRA metals will be used instead of screening levels when natural background concentrations exceed the screening level (e.g., arsenic on the NNSS). Background is considered the average concentration plus two standard deviations of the average concentration for sediment samples collected by the Nevada Bureau of Mines and Geology throughout the Nevada Test and Training Range (formerly the Nellis Air Force Range) (NBMG, 1998; Moore, 1999). For detected chemical COPCs without established screening levels, the protocol used by the EPA Region 9 in establishing screening levels (or similar) will be used to establish PALs. If used, this process will be documented in the investigation report. 


\section{A.6.2.2 Radionuclide PALs}

The PAL for radioactive contaminants is 25-mrem/yr TED, based upon the Industrial Area exposure scenario. The Industrial Area exposure scenario is described in Industrial Sites Project Establishment of Final Action Levels (NNSA/NSO, 2006). For primary releases, the TED is calculated as the sum of external dose and internal dose. External dose is determined directly from TLD measurements. Internal dose is determined by comparing analytical results from soil samples to RRMGs that were established using the RESRAD computer code (Yu et al., 2001). The RRMGs presented in Table A.6-1 are radionuclide-specific values for radioactivity in surface soils. The RRMG is the value, in picocuries per gram for surface soil, for a particular radionuclide, that would result in an internal dose of $25 \mathrm{mrem} / \mathrm{yr}$ to a receptor (under the appropriate exposure scenario) independent of any other radionuclide (assumes that no other radionuclides contribute dose). The internal dose associated with any specific radionuclide would be established using the following equation:

\section{Internal dose $(\mathrm{mrem} / \mathrm{yr})=[$ Analytical result $(\mathrm{pCi} / \mathrm{g}) / \mathrm{RRMG}]$ x $25 \mathrm{mrem} / \mathrm{yr}$}

When more than one radionuclide is present, the internal dose will be calculated as the sum of the internal doses for each radionuclide. In the RESRAD calculation, several input parameters are not specified so that site-specific information can be used. The default and site-specific input parameters used in the RESRAD calculation of RRMGs for each exposure scenario are listed in Attachment A-1.

Table A.6-1

Residual Radioactive Material Guideline Values

(Page 1 of 2)

\begin{tabular}{|c|c|c|c|}
\hline \multirow{2}{*}{ Radionuclide } & \multicolumn{3}{|c|}{ Exposure Scenario (pCi/g) } \\
\cline { 2 - 4 } & Industrial Area & $\begin{array}{c}\text { Remote Work } \\
\text { Area }\end{array}$ & $\begin{array}{c}\text { Occasional Use } \\
\text { Area }\end{array}$ \\
\hline \hline Am-241 & 2,816 & 16,120 & 45,550 \\
\hline Co-60 & 551,300 & $7,229,000$ & $74,210,000$ \\
\hline Cs-137 & 140,900 & $1,955,000$ & $27,560,000$ \\
\hline Eu-152 & $1,177,000$ & $13,240,000$ & $81,740,000$ \\
\hline Eu-154 & 846,900 & $9,741,000$ & $63,530,000$ \\
\hline Eu-155 & $5,588,000$ & $66,450,000$ & $475,100,000$ \\
\hline Nb-94 & $3,499,000$ & $39,660,000$ & $249,200,000$ \\
\hline
\end{tabular}




\section{Table A.6-1 \\ Residual Radioactive Material Guideline Values}

(Page 2 of 2)

\begin{tabular}{|c|c|c|c||}
\hline \multirow{2}{*}{ Radionuclide } & \multicolumn{3}{|c|}{ Exposure Scenario (pCi/g) } \\
\cline { 2 - 4 } & Industrial Area & $\begin{array}{c}\text { Remote Work } \\
\text { Area }\end{array}$ & $\begin{array}{c}\text { Occasional Use } \\
\text { Area }\end{array}$ \\
\hline \hline Pu-238 & 2,423 & 13,880 & 39,220 \\
\hline Pu-239/240 & 2,215 & 12,680 & 35,820 \\
\hline Sr-90 & 59,470 & 807,500 & $9,949,000$ \\
\hline Th-232 & 2,274 & 13,410 & 38,520 \\
\hline$U-234$ & 19,600 & 137,900 & 447,000 \\
\hline U-235 & 20,890 & 149,600 & 492,200 \\
\hline$U-238$ & 21,200 & 155,400 & 336,100 \\
\hline
\end{tabular}

\section{A.6.3 Decision Rules}

The decision rules applicable to both Decision I and Decision II are as follows:

- If COC contamination is inconsistent with the CSM or extends beyond the spatial boundaries identified in Section A.5.2, then work will be suspended and the investigation strategy will be reconsidered, else the decision will be to continue sampling.

The decision rules for Decision I are as follows:

- If the population parameter of any COPC in the Decision I population of interest (defined in Step 4) exceeds the corresponding FAL, then that contaminant is identified as a COC, and Decision II samples will be collected, else no further investigation is needed for that COPC in that population.

- If a COC exists at any CAS, then a corrective action will be determined, else no further action will be necessary.

- If a waste is present that, if released, has the potential to cause the future contamination of site environmental media, then a corrective action will be determined, else no further action will be necessary. 
The decision rules for Decision II are as follows:

- If the population parameter (the observed concentration of any COC) in the Decision II population of interest (defined in Step 4) exceeds the corresponding FAL or potential remediation wastes have not been adequately defined, then additional samples will be collected to complete the Decision II evaluation, else the extent of the COC contamination has been defined.

- If valid analytical results are available for the waste characterization samples defined in Section A.8.0, then the decision will be that sufficient information exists to determine potential remediation waste types and evaluate the feasibility of remediation alternatives, else collect additional waste characterization samples. 


\section{A.7.0 Step 6 - Specify Performance or Acceptance Criteria}

Step 6 of the DQO process defines the decision hypotheses, specifies controls against false rejection and false acceptance decision errors, examines consequences of making incorrect decisions from the test, and places acceptable limits on the likelihood of making decision errors.

\section{A.7.1 Decision Hypotheses}

The baseline condition (i.e., null hypothesis) and alternative condition for Decision I are as follows:

- Baseline condition - A COC is present.

- Alternative condition - A COC is not present.

The baseline condition (i.e., null hypothesis) and alternative condition for Decision II are as follows:

- Baseline condition - The extent of a COC has not been defined.

- Alternative condition - The extent of a COC has been defined.

Decisions and/or criteria have false negative or false positive errors associated with their determination. The impact of these decision errors and the methods that will be used to control these errors are discussed in the following subsections. In general terms, confidence in DQO decisions based on judgmental sampling results will be established qualitatively by the following:

- Developing a CSM (based on process knowledge) that is agreed to by stakeholder participants during the DQO process.

- $\quad$ Testing the validity of the CSM based on investigation results.

- Evaluating the quality of data based on DQI parameters.

\section{A.7.2 False Negative Decision Error}

The false negative decision error would mean deciding that a COC is not present when it actually is (Decision I), or deciding that the extent of a COC has been defined when it has not (Decision II). In both cases, the potential consequence is an increased risk to human health and environment. 


\section{A.7.2.1 False Negative Decision Error for Judgmental Sampling}

In judgmental sampling, the selection of the number and location of samples is based on knowledge of the feature or condition under investigation and on professional judgment (EPA, 2002b).

Judgmental sampling conclusions about the target population depend upon the validity and accuracy of professional judgment.

The false negative decision error (where consequences are more severe) for judgmental sampling designs is controlled by meeting these criteria:

- For Decision I, having a high degree of confidence that the sample locations selected will identify COCs if present anywhere within the CAS. For Decision II, having a high degree of confidence that the sample locations selected will identify the extent of COCs.

- Having a high degree of confidence that analyses conducted will be sufficient to detect any COCs present in the samples.

- Having a high degree of confidence that the dataset is of sufficient quality and completeness.

To satisfy the first criterion, Decision I samples must be collected in areas most likely to be contaminated by COCs (supplemented by unbiased samples where appropriate). Decision II samples must be collected in areas that represent the lateral and vertical extent of contamination (above FALs). The following characteristics must be considered to control decision errors for the first criterion:

- Source and location of release

- Chemical nature and fate properties

- Physical transport pathways and properties

- Hydrologic drivers

These characteristics were considered during the development of the CSM and selection of sampling locations. The field-screening methods and biasing factors listed in Section A.4.2.1 will be used to further ensure that appropriate sampling locations are selected to meet these criteria. Radiological survey instruments and field-screening equipment will be calibrated and checked in accordance with the manufacturer's instructions and approved procedures. The investigation report will present an assessment on the DQI of representativeness that samples were collected from those locations that best represent the populations of interest as defined in Section A.5.1. 
To satisfy the second criterion, Decision I soil samples will be analyzed for the chemical and radiological parameters listed in Section 3.2. Decision II soil samples will be analyzed for those chemical and radiological parameters that identified unbounded COCs. The DQI of sensitivity will be assessed for all analytical results to ensure that all sample analyses had measurement sensitivities (detection limits) that were less than or equal to the corresponding FALs. If this criterion is not achieved, the affected data will be assessed (for usability and potential impacts on meeting site characterization objectives) in the investigation report.

To satisfy the third criterion, the entire dataset of soil sample results, as well as individual soil sample results, will be assessed against the DQIs of precision, accuracy, comparability, and completeness as defined in the Industrial Sites QAPP (NNSA/NV, 2002a) and in Section 6.2.2. The DQIs of precision and accuracy will be used to assess overall analytical method performance as well as to assess the need to potentially "flag” (qualify) individual contaminant results when corresponding QC sample results are not within the established control limits for precision and accuracy. Data qualified as estimated for reasons of precision or accuracy may be considered to meet the analyte performance criteria based on an assessment of the data. The DQI for completeness will be assessed to ensure that all data needs identified in the DQO have been met. The DQI of comparability will be assessed to ensure that all analytical methods used are equivalent to standard EPA methods so that results will be comparable to regulatory action levels that have been established using those procedures. Strict adherence to established procedures and QA/QC protocol protects against false negatives. Site-specific DQIs are discussed in more detail in Section 6.2.2.

To provide information for the assessment of the DQIs of precision and accuracy, the following QC samples will be collected as required by the Industrial Sites QAPP (NNSA/NV, 2002a):

- Field duplicates (minimum of 1 per matrix per 20 environmental samples)

- Laboratory QC samples (minimum of 1 per matrix per 20 environmental samples or 1 per CAS per matrix, if less than 20 collected)

\section{A.7.2.2 False Negative Decision Error for Probabilistic Sampling}

The false negative decision error rate goal was established by the DQO meeting participants at 5 percent. Upon validation of the analytical results, statistical parameters will be calculated for each 
significant COPC identified at each site. Protection against a false negative decision error is contingent upon the following:

- Population distribution

- Sample size

- Actual variability

- Measurement error

Control of the false negative decision error for probabilistic sampling designs is accomplished by ensuring that the following requirements are met for each of the significant COPCs:

- The population distributions fit the applied UCL determination method.

- A sufficient sample size was collected.

- The actual standard deviation is calculated.

- Analyses conducted were sufficient to detect contamination exceeding FALs.

\section{A.7.3 False Positive Decision Error}

The false positive decision error would mean deciding that a COC is present when it is not, or a COC is unbounded when it is not, resulting in increased costs for unnecessary sampling and analysis.

False positive results are typically attributed to laboratory and/or sampling/handling errors that could cause cross contamination. To control against cross contamination, decontamination of sampling equipment will be conducted according to established and approved procedures, and only clean sample containers will be used. To determine whether a false positive analytical result may have occurred, the following QC samples will be collected as required by the Industrial Sites QAPP (NNSA/NV, 2002a):

- Trip blanks (1 per sample cooler containing VOC environmental samples)

- Equipment blanks (1 per sampling event)

- Source blanks (1 per uncharacterized source lot per lot)

- Field blanks (minimum of 1 for the sampling effort, additional if field conditions change)

For probabilistic sampling, false positive decision error rate goal was established by the DQO meeting participants at 0.20 (or 20 percent probability). Protection against this decision error is also afforded by the controls listed in Section A.7.2 for probabilistic sampling designs. 


\section{A.8.0 Step 7 - Develop the Plan for Obtaining Data}

Step 7 of the DQO process selects and documents a design that will yield data that will best achieve performance or acceptance criteria. Judgmental sampling schemes will be implemented to select sample plot locations for the primary releases. Probabilistic sampling schemes will be implemented to select the sample locations within each of the sample plots. Judgmental sampling will also be used to investigate any other releases as described in Section A.2.2.1. Investigation results will be compared to FALs to determine the need for corrective action. Potential source material sample results will be evaluated against the PSM criteria listed in Section A.3.1 to determine the need for corrective action.

\section{A.8.1 Internal Dose Sampling for Primary Releases}

\section{A.8.1.1 Judgmental Sample Plot Locations}

A judgmental sampling design will be implemented for locating Decision I sample plots for the primary release scenario outside the default contamination boundaries. These sample locations have been determined judgmentally based on the highest results of the radiological walkover surveys and the presence of asphalt-covered soil at one location. This will be done in an effort to find the location where the internal dose contributes the greatest amount to TED.

Because the device tested at 11a was composed of primarily enriched uranium compared to plutonium and uranium devices tested at $11 \mathrm{~b}, 11 \mathrm{c}$, and 11d, two sets of Decision I sample plots will be selected. Therefore, CAS 11-23-01 (11a) will be investigated individually, while CASs 11-23-02 (11b), 11-23-03 (11c), and 11-23-04 (11d) will be investigated as a group.

For the primary release at 11a, one Decision I sample plot will be located south of and partially within the 11a trench. This location was selected based on the highest results of the radiological survey conducted during the preliminary investigation. The proposed Decision I sampling plot location is depicted on Figure A.8-1.

Three Decision I sample plots have been selected (outside the default contamination boundaries) for the primary release associated with the tests conducted at $11 \mathrm{~b}, 11 \mathrm{c}$, and $11 \mathrm{~d}$. Two of the sample plots 


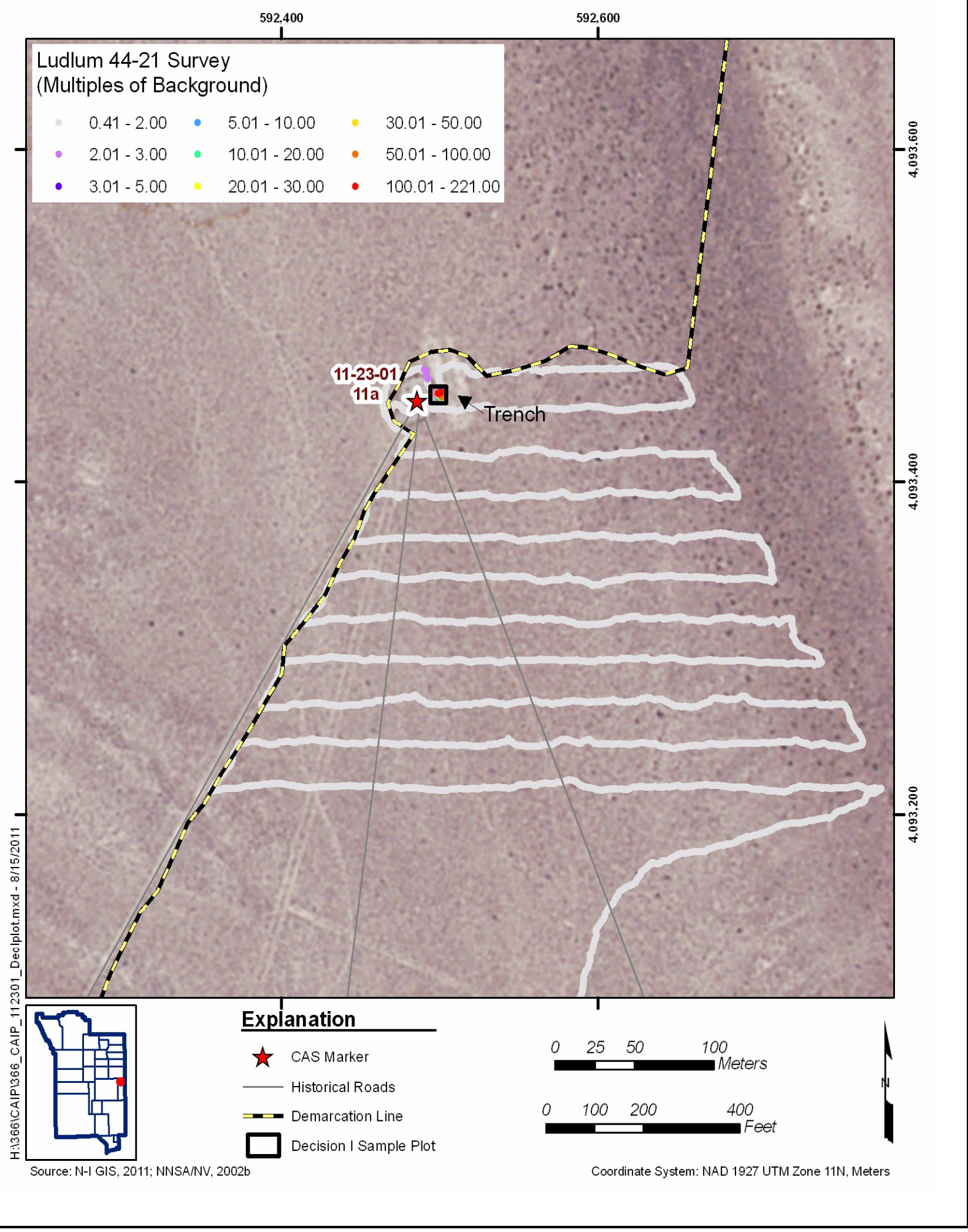

Figure A.8-1

Decision I Sample Plot - Test Area 11a 
have been selected at locations with the most elevated radiological readings resulting from the walkover survey. There will be one sample plot north of the 11c HCA and one sample plot south of the 11d HCA. Because the radiological readings are not as elevated near 11b, there will not be any Decision I sample plots near the 11b HCA. The third sample plot selected for the primary release associated with 11b, 11c, and 11d was selected in the asphalt-covered soil area near the 11c HCA. This area was selected because it is unknown what the true radiological conditions are at this location. The proposed Decision I sampling plot locations are depicted on Figures A.8-2 and A.8-3.

A judgmental sampling design will also be implemented for locating Decision II sample plots. Sample plot locations have been selected judgmentally based on radiological surveys and aerial radiological surveys. These data will be used to establish patterns of contaminant distribution. Six initial Decision II sample plots will be established for the $11 \mathrm{~b}, 11 \mathrm{c}$, and $11 \mathrm{~d}$ primary release. Three sample plots will be judgmentally established along each of two vectors that are approximately normal to the radiation survey isopleths with the constraint that, on each vector, at least one sample plot will present a TED less than the FAL. The approximate proposed sampling vectors and sample plots are shown on Figures A.8-4 and A.8-5.

\section{A.8.1.2 Sampling of Sample Plots}

The probabilistic sampling scheme will be implemented to select sample locations within the sample plots and evaluate the analytical results. For each sample collected within the sample plot, randomly selected subsample locations will be chosen using a random start, triangular pattern (see Figure A.8-6). If sufficient sample material cannot be collected at a specified location (e.g., rock, caliche or buried concrete), the Site Supervisor will establish the location at the nearest place that a surface sample can be obtained.

Statistical methods that generate site characteristics will be used to establish internal dose estimates that represent the sample plot as a whole. Composite samples will be collected at each sample plot in the following manner:

- At least four composite samples will be collected from each established sample plot. 


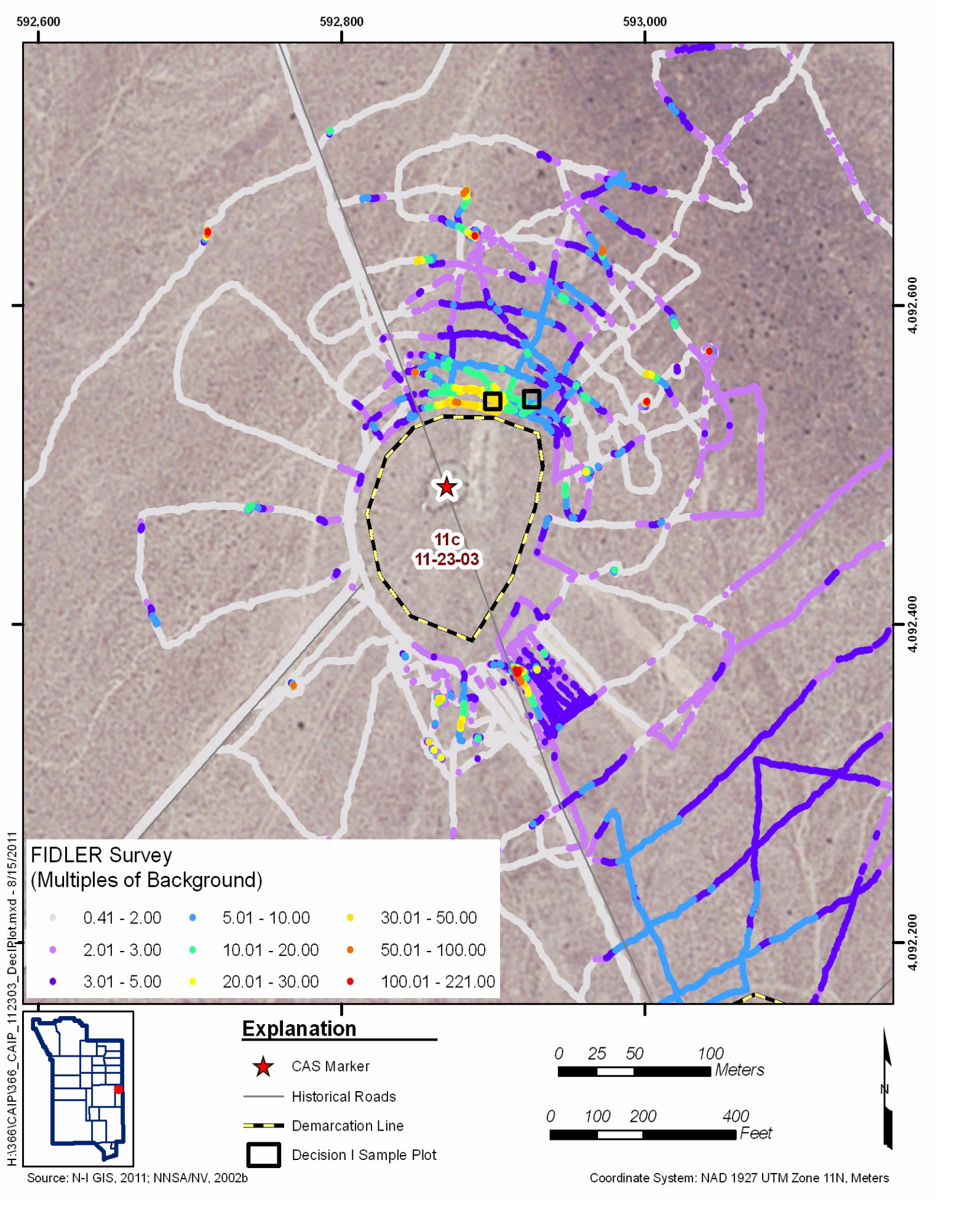

Figure A.8-2

Decision I Sample Plots for Test Areas 11b, 11c, and 11d - View 1 


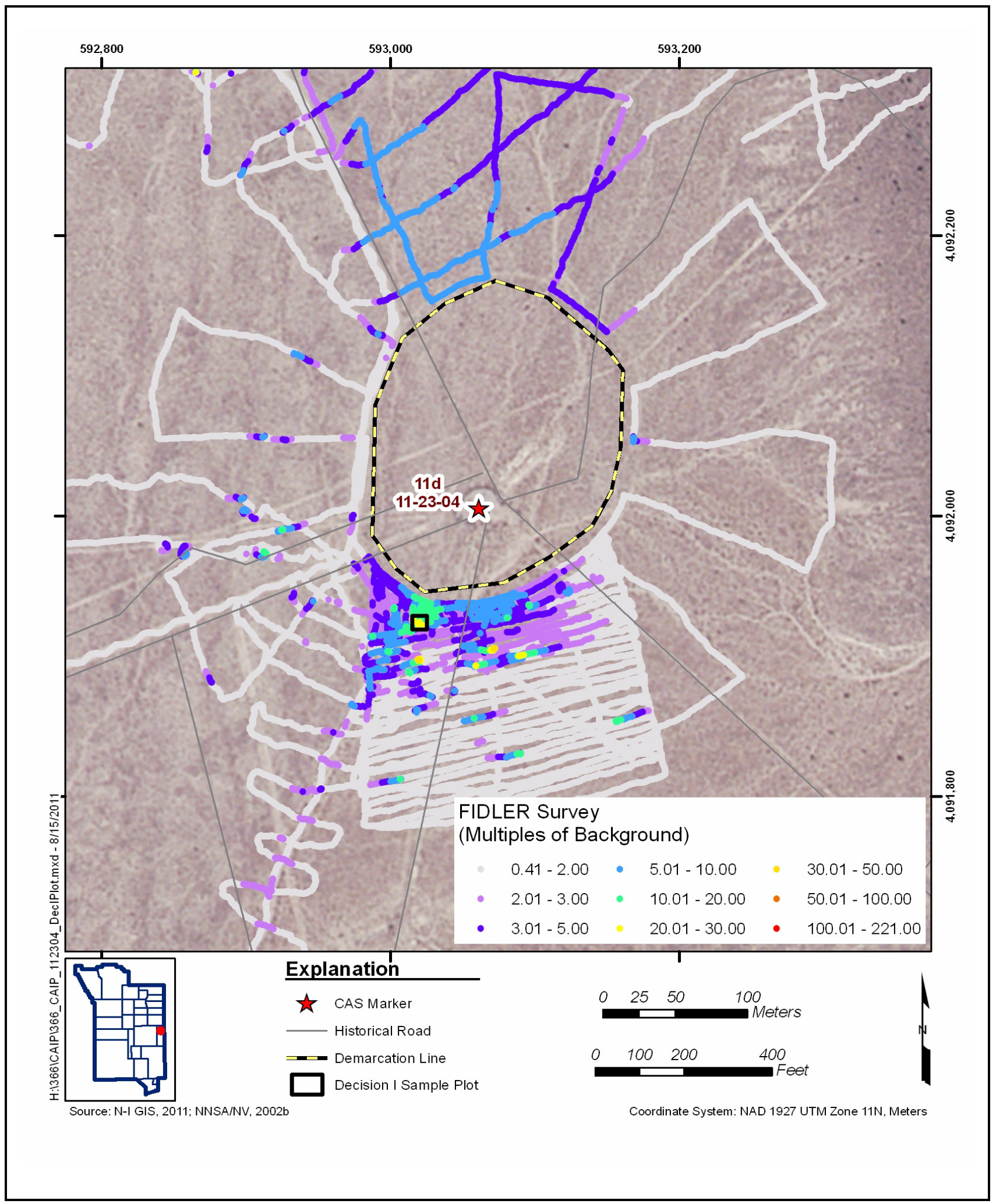

Figure A.8-3

Decision I Sample Plots for Test Areas 11b, 11c, and 11d - View 2 


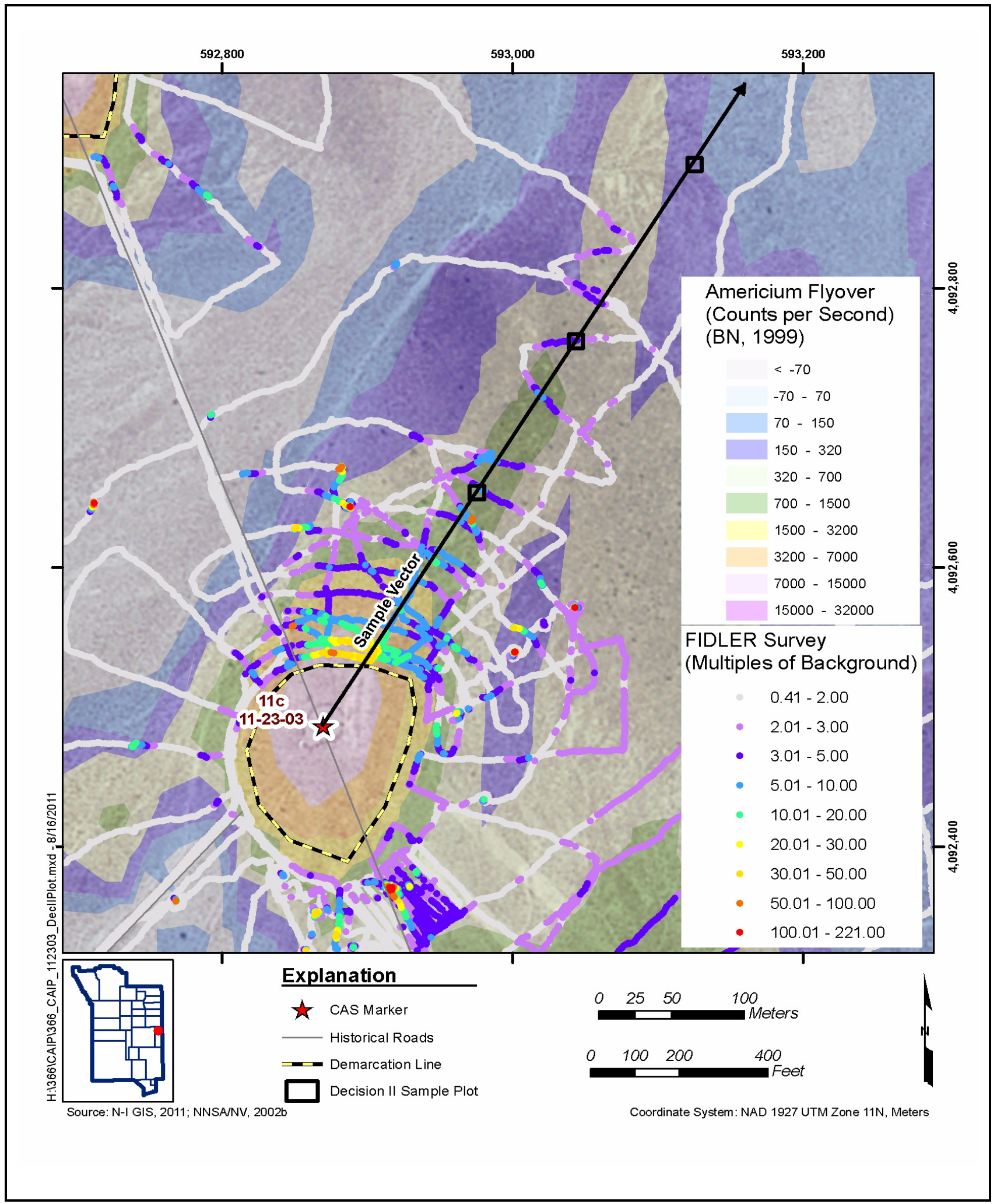

Figure A.8-4

Decision II Sample Plots and TLD Locations for Test Areas 11b, 11c, and 11d - View 1 


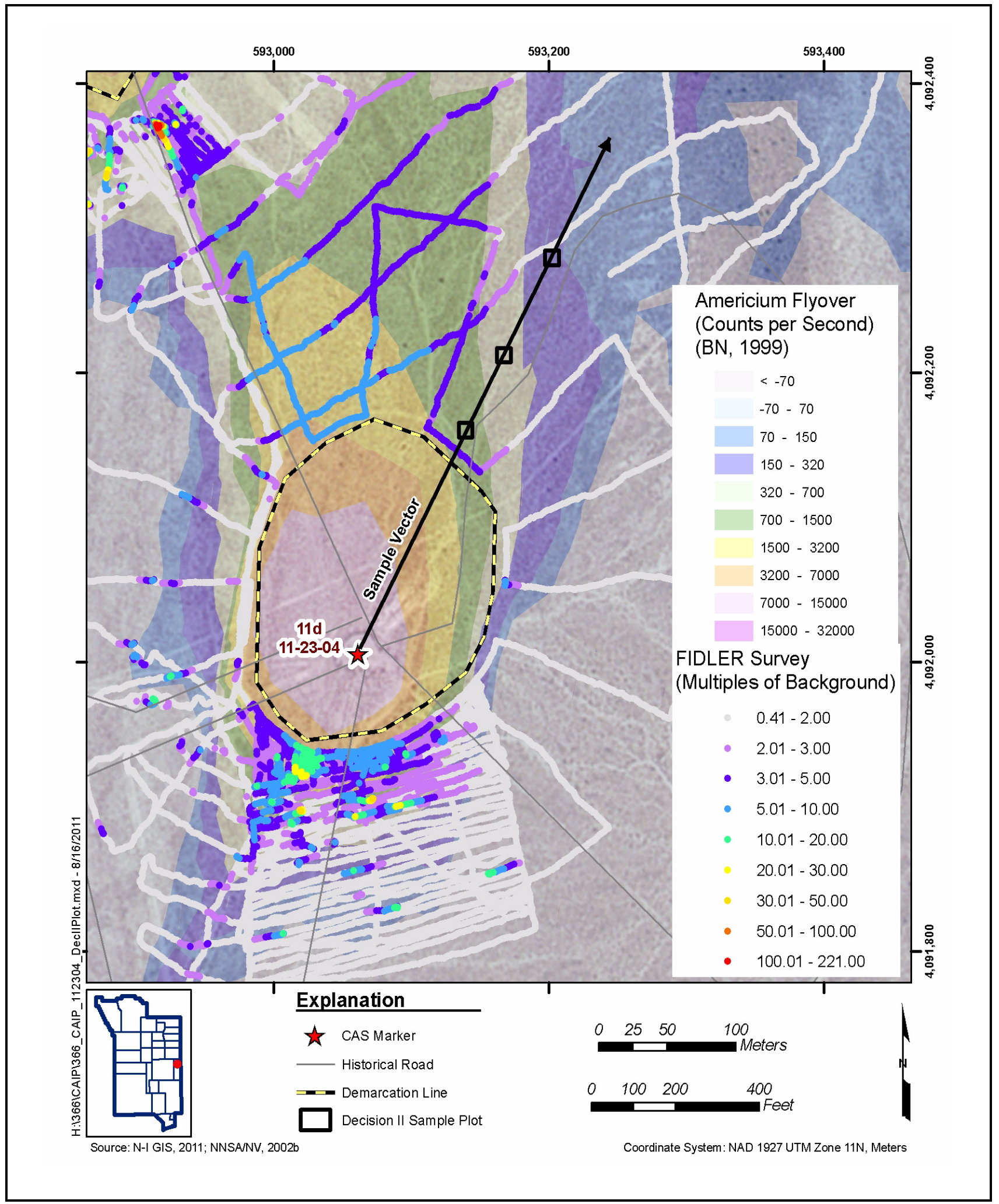

Figure A.8-5

Decision II Sample Plots and TLD Locations for Test Areas 11b, 11c, and 11d - View 2 
- Each composite sample will comprise nine aliquots taken from randomly selected locations within each plot. These locations will be predetermined using a random start with a triangular grid pattern.

- Samples will be sieved to eliminate material greater than 0.25 -in. diameter that cannot effectively be inhaled or ingested.

- The entire volume of the composited material collected will be submitted to the laboratory for analysis.

An example of the predetermined sample locations at one plot is shown on Figure A.8-6.

As determination of the minimum sample size cannot be accomplished until after the data have been generated, the sufficiency of the number of samples collected will be evaluated. This will be evaluated based on TED results (composed of individual internal dose rates associated with each of the four composite samples added to the external dose rates from the TLD elements). The minimum number of samples required for each sample plot was calculated for both the internal (soil samples) and external (TLD elements) dose samples. The minimum sample size was calculated using the following EPA sample size formula (EPA, 2006):

$$
\mathrm{n} \geq \frac{\mathrm{s}^{2}\left(\mathrm{z}_{.95}+\mathrm{z}_{.80}\right)^{2}}{(\mu-\mathrm{C})^{2}}+\frac{\mathrm{z}_{.95}{ }^{2}}{2}
$$

where:

$$
\begin{aligned}
& \mathrm{s}=\text { standard deviation } \\
& \mathrm{z}_{.95}=\mathrm{z} \text { score associated with the false negative rate of } 5 \text { percent } \\
& \mathrm{z}_{.80}=\mathrm{z} \text { score associated with the false positive rate of } 20 \text { percent } \\
& \mu=\text { dose level where false positive decision is not acceptable }(12.5 \mathrm{mrem} / \mathrm{yr}) \\
& \mathrm{C}=\mathrm{FAL}(25 \mathrm{mrem} / \mathrm{yr})
\end{aligned}
$$

The use of this formula requires the input of basic statistical values associated with the sample data. Data from a minimum of three samples is required to calculate these statistical values and as such, the least possible number of samples required to apply the formula is three. Therefore, in instances where the formula resulted in a value less than three, three is adopted as the minimum number of samples required. 


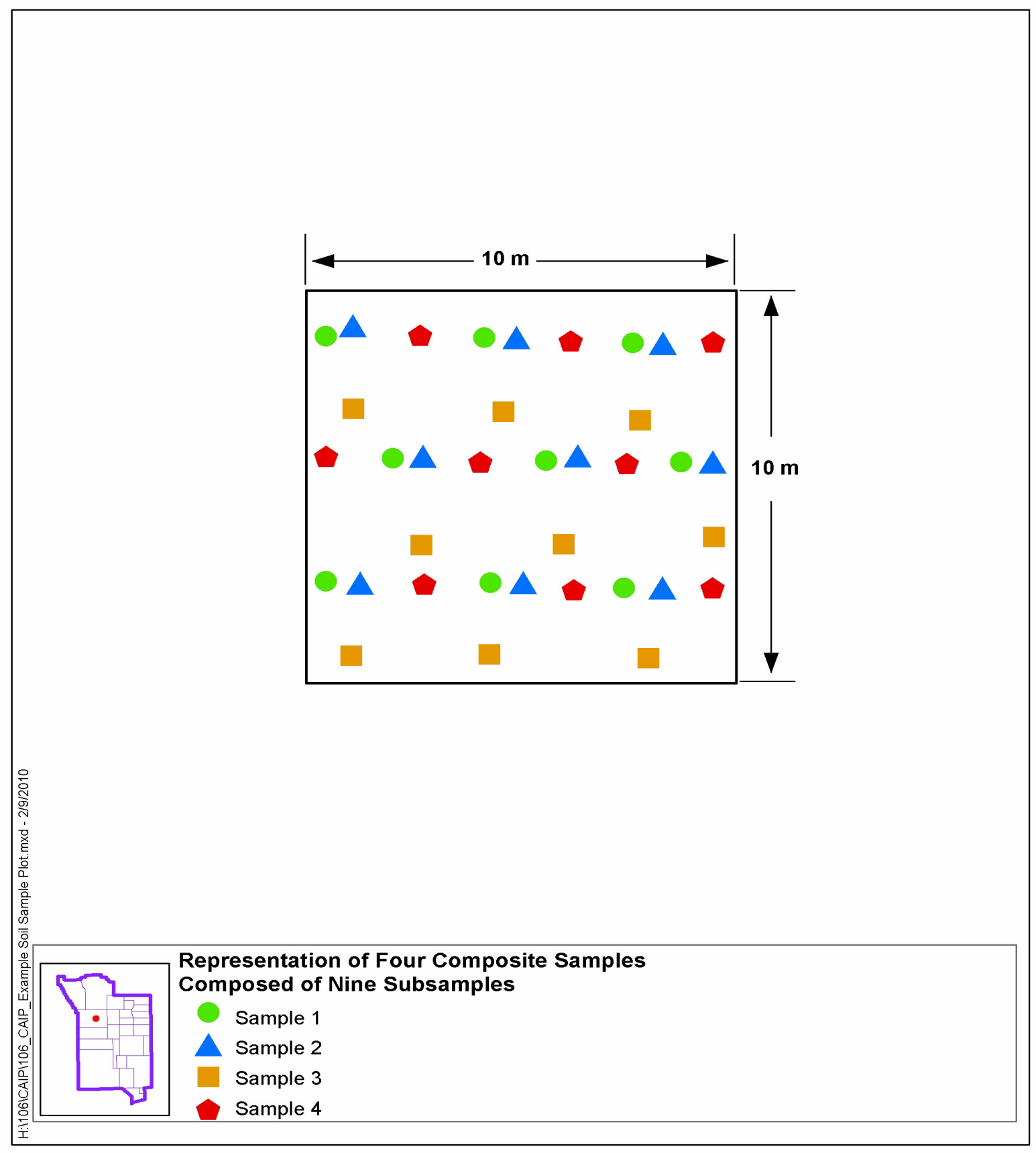

Figure A.8-6

Example Probabilistic Sampling Scheme at a Sample Plot 
The input parameters to be used in calculating the minimum sample size are as follows:

- A confidence level that a false negative error will not occur will be set at 95 percent.

- A confidence level that a false positive error will not occur will be set at 80 percent.

- A gray region width equal to 50 percent of the FAL (12.5 mrem/yr).

- The standard deviation of the TEDs at each plot.

All calculations for the determination of sample size sufficiency will be provided in the investigation report. If the criteria established in this section result in a determination that the minimum sample size was not met for a plot, one of the following actions may be taken:

- Additional composite sample(s) may be collected.

- Conservatively assume that the TED for the plot exceeds the FAL.

If these criteria cannot be met, justifications for use of the resulting TED without meeting the criteria will be made in the investigation report.

\section{A.8.2 External Dose Sampling for Primary Releases}

External dose (penetrating radiation dose for the purposes of this document) will be determined by collecting in situ measurements using TLDs. External dose measurements will be taken at a single sample location or the approximate center of each sample plot at a height of $1 \mathrm{~m}(3.3 \mathrm{ft})$.

The TLD placement and processing will follow the protocols established in Nevada Test Site Routine Radiological Environmental Monitoring Plan (BN, 2003). The TLDs will be in place for a targeted total exposure time of 2,250 hours, or the resulting data will be adjusted to be equivalent to an exposure time of 2,250 hours.

Estimates of external dose, in mrem/IA-yr, will be presented as net values (e.g., a background has been subtracted from the raw result). Naturally occurring terrestrial and cosmic radiation (i.e., background) will be registered on a TLD. These background radiation values can be comparable to the value of the FAL. Therefore, the FAL is only applicable to radiation dose from man-made sources at the NNSS and is a value in excess of what would be present if there were no nuclear activities at the site. 
The value for the natural background dose to be subtracted from the TLD results will be obtained from an area determined to be unaffected by man-made activities at the NNSS. Ten such areas are identified in Section 5.0 of the Nevada Test Site Environmental Report 2006 (Wills, 2007) and are routinely monitored for external radiation exposure via environmental monitoring TLDs.

The project-specific TLDs are subjected to the same QA checks as the routine NNSS environmental monitoring TLDs, as described in Section 6.0. The Panasonic UD-814 TLD used in the NNSS environmental monitoring program contains four individual elements. The readings from each element are compared as part of the routine QA checks during the TLD processing. External dose at each TLD location is then determined using the readings from TLD elements 2, 3, and 4. Element 1 is designed to measure dose to the skin and is not relevant to the determination of the external dose.

\section{A.8.3 Evaluation of TED for Primary Releases}

As discussed in Section A.6.1.2, the 95 percent UCL of the TED from each sample location will be used to establish the corrective action boundary. The 95 percent UCL of the TED for each sample location will be established as the sum of the 95 percent UCL of the internal dose and the 95 percent UCL of the external dose. These 95 percent UCL dose estimates will be calculated using the external dose measurements from the TLD and the RESRAD-calculated internal dose estimates from the soil samples.

The initial corrective action boundary area will be calculated using the 95 percent UCL of the TED from each sample location and a corresponding measurement from an appropriate radiation survey. These paired values will be used to establish a correlation for each radiation survey and identify the radiation survey that has the best correlation to TED. This correlation will be used to establish a radiation survey value corresponding to the 25-mrem/yr FAL (using the appropriate exposure scenario). An isopleth of this value from the radiological survey will be used as the initial corrective action boundary.

\section{A.8.4 Sampling for Other Releases}

Sample locations for other releases will be determined based upon the likelihood of a contaminant release at the CAS. These locations will be selected based on the identification of biasing factors 
during the investigation. For the decontamination station and hot park, a sample plot will be selected based on the highest radiological readings identified from a radiological walkover survey. The survey will be conducted in the areas most likely for a release associated with these two facilities to have occurred. For the investigation of drainages, sample locations will be selected from the center of the sediment collection areas or at locations of elevated radiological readings.

The following factors will also be considered in selecting locations for analytical samples at CAU 366:

- Drums, containers, equipment, or debris: Materials that contain or may have contained hazardous or radioactive substances.

- Lithology: Locations where variations in lithology (soil or rock) indicate that different conditions or materials exist.

- Preselected areas based on process knowledge of the site: Locations for which evidence such as historical photographs or maps, experience from previous investigations, or interviewee's input exists that a release of hazardous or radioactive substances may have occurred.

- Preselected areas based on process knowledge of the contaminant(s): Locations that may reasonably have received contamination, selected on the basis of the chemical and/or physical properties of the contaminant(s) in that environmental setting.

- Visual indicators such as discoloration, textural discontinuities, disturbance of native soils, or any other indication of potential contamination.

- Other biasing factors: Factors not previously defined for the CAI that become evident once the investigation of the site is under way.

Biasing factors such as stains, radiological survey results, and wastes suspected of containing hazardous or radiological components will be used to select the most appropriate samples from a particular location for submittal to the analytical laboratory. As biasing factors are identified and used for selection of sampling locations, they will be documented in the appropriate field documents. A TLD will be placed at all sample locations.

\section{A.8.4.1 Decision I}

A judgmental sampling design will be implemented for the other releases for establishing sample locations and evaluating sample results. For radiological other releases (i.e., decontamination 
station), the primary release sampling scheme will be implemented (Sections A.8.1.1 and A.8.1.2). For chemical other releases, individual sample results, rather than an average concentration, will be used to compare to FALs. Therefore, statistical methods to generate site characteristics will not be needed. Adequate representativeness of the entire target population may not be a requirement to developing a sampling design. If good prior information is available on the target site of interest, then the sampling may be designed to collect samples only from areas known to have the highest concentration levels on the target site. If the observed concentrations from these samples are below the action level, then a decision can be made that the site contains safe levels of the contaminant without the samples being truly representative of the entire area (EPA, 2006).

A biased sampling strategy will be used to target areas with the highest potential to contain a COC, if it is present anywhere in the CAS. Sample locations will be determined based on process knowledge, previously acquired data, or the field-screening and biasing factors listed in Section A.8.4. If biasing factors are present in soils below locations where Decision I samples were removed, additional Decision I soil samples will be collected at depth intervals selected by the Site Supervisor based on biasing factors to a depth where the biasing factors are no longer present. The Site Supervisor has the discretion to modify the judgmental sample locations, but only if the modified locations meet the decision needs and criteria stipulated in DQOs.

Previously identified other releases associated with CAU 366 are the two CWDs, 11a trench, 11d drainage, and former decontamination station and hot park (Figure A.8-7). The following sections describe the sampling plan developed for these other releases.

\section{A.8.4.1.1 Contaminated Waste Dumps \#1 and \#2}

It has been determined that the area within the radiological posted fence line encompassing CASs 11-08-01 and 11-08-02 will require corrective action (Section 4.1). However, to ensure that the waste dumps are contained within this boundary, a geophysical survey will be conducted inside and outside the fence at CAS 11-08-01 (posted URMA) and outside the fence at CAS 11-08-02 (posted HCA and URMA). No soil samples will be collected at either CAS. 


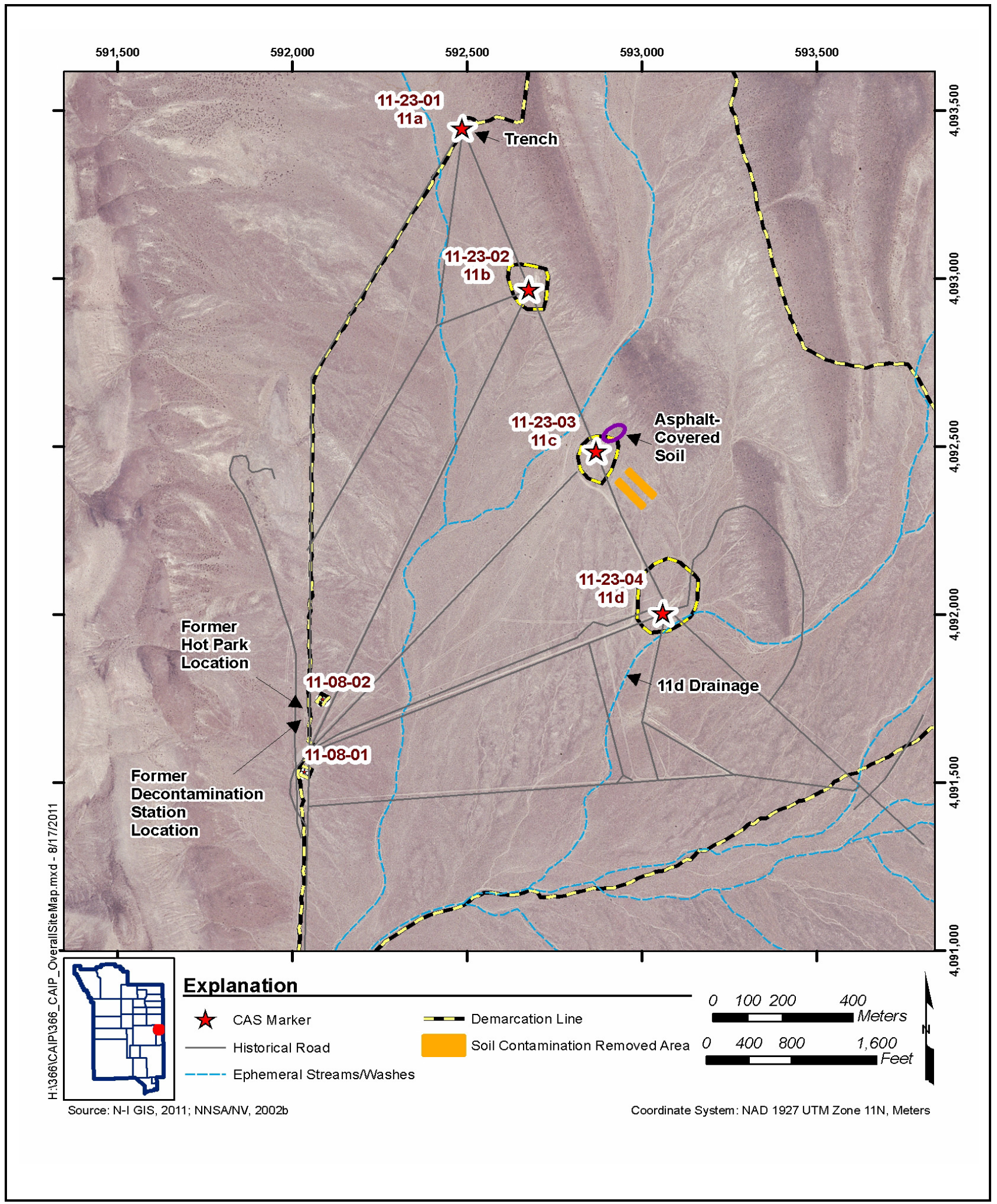

Figure A.8-7

CAU 366, Site Map 


\section{A.8.4.1.2 11a Trench}

A geophysical survey will be conducted over the accessible portions of the trench, to include the excavated area as well as the spoils pile. If buried debris is detected, that area will require corrective action, and a default contamination boundary will be established to encompass all of the buried material. If other biasing factors are identified during the investigation of the trench (i.e., stains, waste), judgmental soil samples will be collected and analyzed for the appropriate constituents. A TLD will be placed at all sample locations.

\section{A.8.4.1.3 11d Drainage}

This drainage will be visually surveyed from outside the 11d HCA to the detention basin for the presence of sediment accumulation areas within the wash. A sampling location will be established at the center of the nearest two sediment accumulation areas (which may include the detention basin) outside the default corrective action boundary of 11d. Judgmental samples will be collected as follows:

- At each sample location within the sediment accumulation area, a sample will be collected from each 5-cm depth interval until native material is encountered.

- Each sample will be field screened with an alpha/beta contamination meter and compared to the established background FSL for the site.

- If the depth sample with the highest FSR is not significantly different (at least 20 percent difference) than the FSR of the surface sample, then only the surface sample will be submitted for analysis. If the FSR is greater than 20 percent higher than the surface sample, then both the surface sample and the depth sample with the elevated FSR will be submitted for analysis.

- If the FSL is not exceeded in any depth sample, then only the surface sample will be submitted for analysis.

Figure A.8-8 shows an example of this sampling scheme.

It will be conservatively assumed that the highest TED from either surface or subsurface samples will be used to resolve DQO decisions. If a subsurface sample results in a higher internal dose than a surface sample, a TLD-equivalent external dose will be calculated for the subsurface sample. This will be accomplished by establishing a correlation between RESRAD-calculated external dose from surface samples and the RESRAD-calculated external dose from the subsurface samples. This 

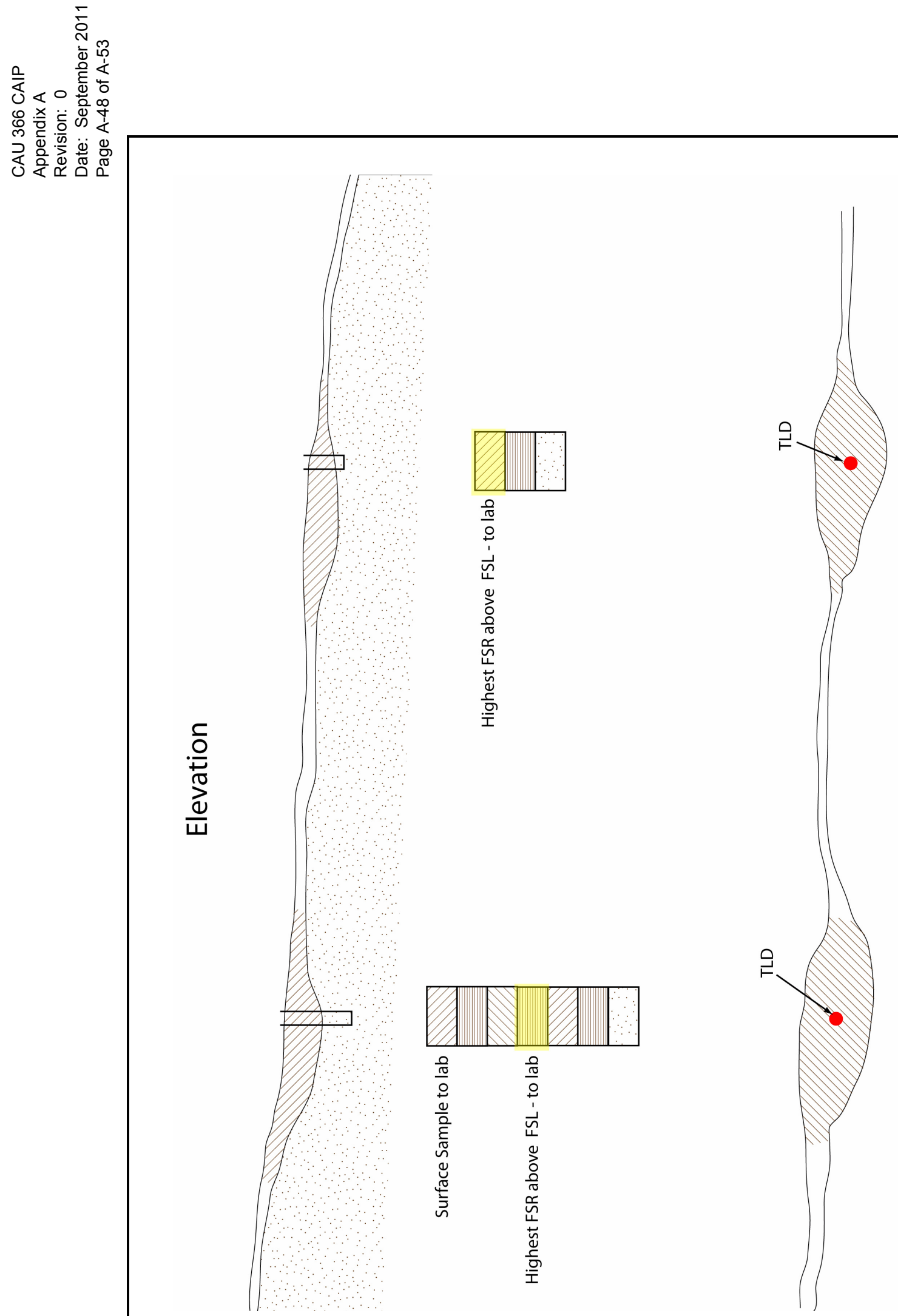

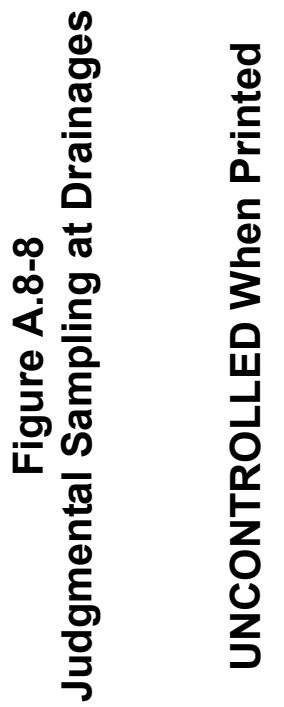


surface TLD reading will be increased by this proportion to estimate a TLD-equivalent external dose for the subsurface soil.

A radiological survey was completed in the upper portion of the wash that included the active channel, overbank deposits, and the younger and older terraces. There were no elevated readings identified that would require a sample to be collected. A radiological survey will be completed on the remainder of the wash. If elevated readings are identified in the active channel, additional samples may be collected using the previously discussed drainage sample scheme. If there are elevated readings in the overbank or terraces, judgmental surface samples may be collected at the location of the most elevated radiological reading. A TLD will be placed at each sample location.

All drainage samples will be submitted for the analyses listed under CAS 11-23-04 in Table A.2-3 because the wash being sampled flows through the $11 \mathrm{~d}$ test area.

Information (such as sample results and the results of the radiological survey) needed to assess the potential for future migration of the $25-\mathrm{mrem} / \mathrm{yr}$ boundary will be obtained during the field investigation and addressed in the closure report.

\section{A.8.4.1.4 Decontamination Station and Hot Park}

The former locations of the decontamination station and hot park will be investigated for potential releases that may have occurred as a result of the activities that took place there. The area encompassing the station and park will be visually and radiologically surveyed. A sample plot will be placed in the area with the most widespread elevated radiological readings. A probabilistic sampling approach (such as for a primary release) will be used to collect the samples within the plot. Because there is no evidence that additional COPCs have been introduced, the samples will be analyzed for the same contaminants associated with the primary release. If biasing factors (i.e., stains, a discharge area) are identified during the visual survey, additional judgmental soil samples will be collected. A TLD will be placed in the center of the sample and at all additional sample locations (if selected). 


\section{A.8.4.1.5 Other Potential Releases}

During the course of the CAU 366 investigation, the identification of any biasing factors (e.g., stains, spills, debris) will be used to determine whether a potential release is present. Samples will be collected from the material that presents the greatest degree of the biasing factor (surface or subsurface as discussed in Section A.8.4). Specific analyses requested for these samples will be determined based on the nature of the potential release (e.g., hydrocarbon stain, lead bricks).

\section{A.8.4.2 Decision II}

Decision II samples for other releases identified during the investigation will be collected from judgmental sampling locations selected based on locations where COCs were detected, the CSM, and other field-screening and biasing factors listed in Section A.8.4. In general, sample locations will be arranged in a triangular pattern around the area containing COCs at distances based on site conditions, process knowledge, and biasing factors. If COCs extend beyond the initial step-outs, Decision II samples will be collected from incremental step-outs. Initial step-outs will include samples from at least as deep as the vertical extent of contamination defined at the Decision I location and the depth of the incremental step-outs will be based on the deepest contamination observed at all locations. A clean sample (i.e., COCs less than FALs) collected from each step-out direction (lateral or vertical) will define extent of contamination in that direction.

If a $\mathrm{COC}$ is found in the $11 \mathrm{~d}$ drainage at a sediment accumulation area sampling location, additional sedimentation areas will be sampled until at least two consecutive sedimentation areas are found that do not contain COCs, and other drainages will be assessed for the potential to have sediment collection areas that contain a COC. Decision II will be resolved by the assumption that the entire volume of sediment in each sediment accumulation area where a COC was identified contains the COC. If a COC is identified as being associated with the drainage but is located outside a sediment accumulation area, Decision II step-out samples will be collected as discussed previously.

\section{A.8.5 Establishment of Final Corrective Action Boundary}

The final corrective action boundary will be established to include the default contamination boundaries, the initial corrective action boundary, and any additional areas that exceed the FAL. 


\section{A.9.0 References}

ARL/SORD, see Air Resources Laboratory/Special Operations and Research Division.

ASTM, see ASTM International.

Air Resources Laboratory/Special Operations and Research Division. 2011. "Nevada Test Site (NTS) Climatological Rain Gauge Network." As accessed at http://www.sord.nv.doe.gov/home_climate_rain.htm on 27 July.

ASTM International. 1995 (reapproved 2002). Standard Guide for Risk-Based Corrective Action Applied at Petroleum Release Sites, ASTM E1739 - 95(2002). Philadelphia, PA.

BN, see Bechtel Nevada.

Bechtel Nevada. 1999. An Aerial Radiological Survey of the Nevada Test Site, DOE/NV/11718--324. Prepared for U.S. Department of Energy, Nevada Operations Office. Las Vegas, NV: Remote Sensing Laboratory.

Bechtel Nevada. 2003. Nevada Test Site Routine Radiological Environmental Monitoring Plan, DOE/NV/11718--804. Prepared for the U.S. Department of Energy, National Nuclear Security Administration Nevada Site Office. Las Vegas, NV.

DOE/NV, see U.S. Department of Energy, Nevada Operations Office.

EPA, see U.S. Environmental Protection Agency.

Moore, J., Science Applications International Corporation. 1999. Memorandum to M Todd (SAIC) titled "Background Concentrations for NTS and TTR Soil Samples," 3 February.

Las Vegas, NV: IT Corporation.

Murphy, T., Bureau of Federal Facilities. 2004. Letter to R. Bangerter (NNSA/NSO) titled "Review of Industrial Sites Project Document Guidance for Calculating Industrial Sites Project Remediation Goals for Radionuclides in Soil Using the Residual Radiation (RESRAD) Computer Code," 19 November. Las Vegas, NV.

NAC, see Nevada Administrative Code.

NBMG, see Nevada Bureau of Mines and Geology.

N-I GIS, see Navarro-Intera Geographic Information Systems. 
NNSA/NSO, see U.S. Department of Energy, National Nuclear Security Administration Nevada Site Office.

NNSA/NV, see U.S. Department of Energy, National Nuclear Security Administration Nevada Operations Office.

Navarro-Intera Geographic Information Systems. 2011. ESRI ArcGIS Software.

Nevada Administrative Code. 2008a. NAC 445A.227, "Contamination of Soil: Order by Director for Corrective Action; Factors To Be Considered in Determining Whether Corrective Action Required." Carson City, NV. As accessed at http://www.leg.state.nv.us/nac on 27 July 2011.

Nevada Administrative Code. 2008b. NAC 445A.22705, "Contamination of Soil: Evaluation of Site by Owner or Operator; Review of Evaluation by Division." Carson City, NV. As accessed at http://www.leg.state.nv.us/nac on 27 July 2011.

Nevada Bureau of Mines and Geology. 1998. Mineral and Energy Resource Assessment of the Nellis Air Force Range, Open-File Report 98-1. Reno, NV.

Thompson, J.L., M.A. Guell, and J.R. Hunt. 1997. Subsurface Nobel Gas Transport at the Nevada Test Site, LA-UR-97-3255. Los Alamos, NM: Los Alamos National Laboratory.

USGS/DOE, see U.S. Geological Survey and U.S. Department of Energy.

U.S. Department of Energy, National Nuclear Security Administration Nevada Operations Office. 2002. Industrial Sites Quality Assurance Project Plan, Rev. 3, DOE/NV--372--REV. 3. Las Vegas, NV.

U.S. Department of Energy, National Nuclear Security Administration Nevada Operations Office. 2002b. Nevada Test Site Orthophoto Site Atlas, DOE/NV/11718--604. Aerial photos acquired Summer 1998. Prepared by Bechtel Nevada. Las Vegas, NV.

U.S. Department of Energy, National Nuclear Security Administration Nevada Site Office. 2006. Industrial Sites Project Establishment of Final Action Levels, Rev. 0, DOE/NV--1107. Las Vegas, NV.

U.S. Department of Energy, Nevada Operations Office. 1992. Remedial Investigation and Feasibility Study for the Plutonium Contaminated Soils at Nevada Test Site, Nellis Air Force Range and Tonopah Test Range. April. Las Vegas, NV.

U.S. Department of Energy, Nevada Operations Office. 2000. United States Nuclear Tests, July 1945 through September 1992, DOE/NV--209-REV 15. Las Vegas, NV. 
U.S. Environmental Protection Agency. 2002a. Calculating Upper Confidence Limits for Exposure Point Concentrations at Hazardous Waste Sites, OSWER 9285.6-10. December. Washington, DC: Office of Emergency and Remedial Response.

U.S. Environmental Protection Agency. 2002b. Guidance for Quality Assurance Project Plans, EPA QA/G5, EPA/240/R-02/009. Washington, DC: Office of Environmental Information.

U.S. Environmental Protection Agency. 2006. Guidance on Systematic Planning Using the Data Quality Objectives Process, EPA QA/G-4, EPA/240/B-06/001. Washington, DC: Office of Environmental Information.

U.S. Environmental Protection Agency. 2011. Pacific Southwest, Region 9: Regional Screening Levels (Formerly PRGs), Screening Levels for Chemical Contaminants. As accessed at http://www.epa.gov/region9/superfund/prg on 27 July. Prepared by EPA Office of Superfund and Oak Ridge National Laboratory.

U.S. Geological Survey and U.S. Department of Energy. 2011. "USGS/U.S. Department of Energy Cooperative Studies in Nevada" web page. As accessed at http://nevada.usgs.gov/doe_nv on 27 July.

Wills, C.A. 2007. Nevada Test Site Environmental Report 2006, DOE/NV 25946--259. Prepared for the U.S. Department of Energy, National Nuclear Security Administration Nevada Site Office. Las Vegas, NV: National Security Technologies, LLC.

Yu, C., A.J. Zielen, J.J. Cheng, D.J. LePoire, E. Gnanapragasam, S. Kamboj, J. Arnish, A. Wallo III, W.A. Williams, and H. Peterson. 2001. User's Manual for RESRAD Version 6, ANL/EAD-4. Argonne, IL: Argonne National Laboratory, Environmental Assessment Division. (Version 6.4 released in December 2007.) 


\title{
Attachment A-1
}

\section{Derivation of Residual Radioactive Material Guidelines for Radionuclides in Soil}

\author{
(10 Pages)
}




\section{Introduction}

This appendix promulgates tables of Residual Radioactive Material Guidelines (RRMGs) for the Industrial Area, Remote Work Area, and Occasional Use Area exposure scenarios, for use in the evaluation of Soils Project sites. These exposure scenarios are described in the document Industrial Sites Project Establishment of Final Action Levels (NNSA/NSO, 2006). Two sets of RRMGs were calculated for each of the three exposure scenarios: one set using only the inhalation and ingestion pathways (e.g., internal dose), and one set that added the external gamma pathway (e.g., internal and external dose). The second set is needed to evaluate "other release" soil samples where thermoluminescent dosimeters (TLDs) were not emplaced to measure the external dose.

\section{Background}

The Industrial Sites Project Establishment of Final Action Levels (NNSA/NSO, 2006), provides a Nevada Division of Environmental Protection (NDEP)-approved process for the derivation of soil sampling final action levels that are congruent with the risk-based corrective action process. This document is used by the Navarro-Intera, LLC, Soils Project as well.

The Residual Radioactive (RESRAD) computer code, version 6.5 (Yu et al., 2001), and the guidance provided in NNSA/NSO (2006) were used to derive RRMGs for use in the Soils Project. The RRMGs are radionuclide-specific values for radioactivity in surface soils, expressed in units of picocuries per gram ( $\mathrm{pCi} / \mathrm{g}$ ). A soil sample with a radionuclide concentration that is equal to the RRMG value for that radionuclide would present a potential dose of 25 millirem per year (mrem/yr) to a receptor under the conditions described in the exposure scenario. When more than one radionuclide is present, the potential dose must be evaluated by summing the fractions for each radionuclide (i.e., the measured concentration divided by the RRMG for the radionuclide). The resultant sum of the fractions value is then multiplied by 25.0 to obtain an estimate of the dose.

The RRMGs are specific to a particular exposure scenario. The dose estimates obtained from the use of RRMGs are valid only when the assumptions provided in the exposure scenario for the intended land-use hold true. In most cases at the Nevada National Security Site (NNSS), the Industrial Area exposure scenario is quite conservative and is bounding for most anticipated future land uses.

A recent revision to 10 Code of Federal Regulations (CFR) Part 835 (CFR, 2011) had adopted new, more sophisticated, dosimetric models and new dosimetric terms. Internal dose is now to be expressed in terms of the Committed Effective Dose (CED), and International Commission on Radiological Protection (ICRP) 72 dose conversion factors are to be used.

\section{Methods}

Calculations were performed using the RESRAD code, version 6.5 (Yu et al., 2001). The ICRP 72 dose conversion factors were used. The RESRAD input parameters were verified and checkprinted. 
The radionuclide niobium $(\mathrm{Nb})-94$ was previously added to the RRMGs to accommodate work in Area 25 that is related to the Nuclear Rocket Development Station (NRDS). The radionuclides silver (Ag)-108m, curium (Cm)-243, and Cm-244 were recently detected on one or more Soils Project sites, and RRMGs were calculated to demonstrate that their contribution to the total effective dose (TED) is negligible.

The RESRAD calculations have identified that for all radionuclides evaluated, with one exception: The maximum potential dose occurs at time-zero. The RRMGs provided in this memorandum do reflect those for time-zero. The exception previously mentioned is the radionuclide thorium (Th)-232, which has several daughters with short half-lives. Because the daughter activity "grows in," and because RRMGs include the contributions from daughters, the maximum potential dose for Th-232 actually occurs at 10.21 years. A RRMG for Th-232 at 10.21 years was not selected, and the RRMG for time-zero was used, for the following reasons:

- RESRAD suggests a set of RRMGs for use when the overall total dose is at its maximum. Considering the contributions from all radionuclide contaminants of potential concern (COPCs), this would be at time-zero.

- The additional dose from the in-growth of Th-232 daughters is offset by the radioactive decay of other radionuclides that would be present (e.g., cesium [Cs]-137).

- The additional dose from the in-growth of Th-232 daughters is very small when compared to the basic dose limit of $25 \mathrm{mrem} / \mathrm{yr}$. For example, if Th-232 were found at a concentration of $100 \mathrm{pCi} / \mathrm{g}$, the increase in potential dose from time-zero to 10.21 years would only be 0.52 millirem (mrem). To date, Th-232 has only been seen on Soils Project sites at environmental levels of about 1.5 to $3 \mathrm{pCi} / \mathrm{g}$.

\section{Assumptions and Default Parameters}

Appendix B to DOE/NV--1107 (NNSA/NSO, 2006) lists the RESRAD code variables (i.e., input parameters) for the three exposure scenarios. These pre-determined values were used to calculate the RRMGs, with a few exceptions as described in Table 1.

\section{$\underline{\text { Results }}$}

The RRMGs are presented in Tables 2 to 7. The abbreviation "RRMG" in each of the six tables includes a subscript to indicate the scenario and the exposure pathways that are activated. When referencing a set of RRMGs, the subscripts should be included to avoid confusion and a potential misapplication of the RRMGs. 


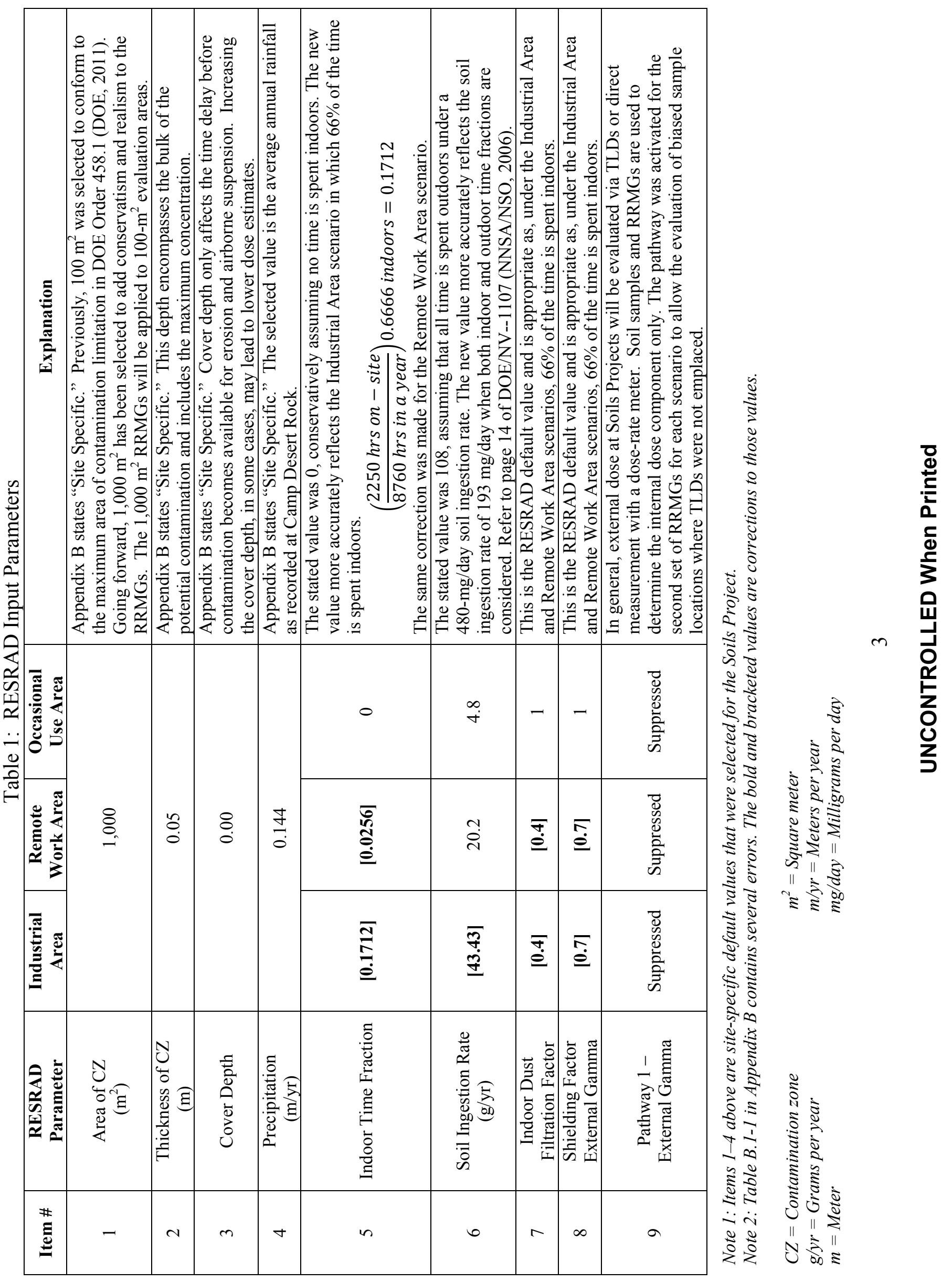


Table 2: Soils Project - Industrial Area Exposure Scenario - Internal Dose Only

\begin{tabular}{|c|c|}
\hline Radionuclide & $\begin{array}{c}\mathbf{R R M G}_{(\mathbf{I A}-\mathrm{I})} \\
(\mathrm{pCi} / \mathrm{g})\end{array}$ \\
\hline Ag- $108 \mathrm{~m}$ & $2.737 \mathrm{E}+06$ \\
\hline Am-241 & $2.816 \mathrm{E}+03$ \\
\hline $\mathrm{Cm}-243$ & $3.852 \mathrm{E}+03$ \\
\hline $\mathrm{Cm}-244$ & $4.735 \mathrm{E}+03$ \\
\hline Co-60 & $5.513 \mathrm{E}+05$ \\
\hline Cs-137 & $1.409 \mathrm{E}+05$ \\
\hline Eu-152 & $1.177 \mathrm{E}+06$ \\
\hline Eu-154 & $8.469 \mathrm{E}+05$ \\
\hline Eu-155 & $5.588 \mathrm{E}+06$ \\
\hline $\mathrm{Nb}-94$ & $3.499 \mathrm{E}+06$ \\
\hline $\mathrm{Pu}-238$ & $2.423 \mathrm{E}+03$ \\
\hline $\mathrm{Pu}-239 / 240$ & $2.215 \mathrm{E}+03$ \\
\hline Sr-90 & $5.947 \mathrm{E}+04$ \\
\hline Th-232 & $2.274 \mathrm{E}+03$ \\
\hline U-234 & $1.960 \mathrm{E}+04$ \\
\hline $\mathrm{U}-235$ & $2.089 \mathrm{E}+04$ \\
\hline $\mathrm{U}-238$ & $2.120 \mathrm{E}+04$ \\
\hline
\end{tabular}

A soil sample at this RRMG value would present an internal dose potential of 25 mrem under the Industrial Area exposure scenario. 
Table 3: Soils Project - Industrial Area Exposure Scenario - Internal \& External Dose

\begin{tabular}{|c|c|}
\hline Radionuclide & $\begin{array}{c}\mathbf{R R M G}_{(\mathbf{I A}-\mathbf{I E})} \\
(\mathrm{pCi} / \mathrm{g})\end{array}$ \\
\hline Ag-108m & $9.281 \mathrm{E}+01$ \\
\hline Am-241 & $1.503 \mathrm{E}+03$ \\
\hline $\mathrm{Cm}-243$ & $3.155 \mathrm{E}+02$ \\
\hline $\mathrm{Cm}-244$ & $4.713 \mathrm{E}+03$ \\
\hline Co-60 & $1.833 \mathrm{E}+01$ \\
\hline Cs-137 & $7.290 \mathrm{E}+01$ \\
\hline Eu-152 & $3.826 \mathrm{E}+01$ \\
\hline Eu-154 & $3.571 \mathrm{E}+01$ \\
\hline Eu-155 & $9.583 \mathrm{E}+02$ \\
\hline $\mathrm{Nb}-94$ & $9.653 \mathrm{E}+01$ \\
\hline $\mathrm{Pu}-238$ & $2.416 \mathrm{E}+03$ \\
\hline $\mathrm{Pu}-239 / 240$ & $2.207 \mathrm{E}+03$ \\
\hline Sr-90 & $7.714 \mathrm{E}+03$ \\
\hline Th-232 & $5.067 \mathrm{E}+02$ \\
\hline U-234 & $1.865 \mathrm{E}+04$ \\
\hline U-235 & $2.555 \mathrm{E}+02$ \\
\hline $\mathrm{U}-238$ & $1.423 \mathrm{E}+03$ \\
\hline
\end{tabular}

A soil sample at this RRMG value would present a TED potential of 25 mrem under the Industrial Area exposure scenario. 
Table 4: Soils Project - Remote Work Area Exposure Scenario - Internal Dose Only

\begin{tabular}{|c|c|}
\hline Radionuclide & $\begin{array}{c}\mathbf{R R M G}_{(\mathbf{R W A}-\mathbf{I})} \\
(\mathrm{pCi} / \mathrm{g})\end{array}$ \\
\hline Ag-108m & $3.389 \mathrm{E}+07$ \\
\hline Am-241 & $1.612 \mathrm{E}+04$ \\
\hline $\mathrm{Cm}-243$ & $2.223 \mathrm{E}+04$ \\
\hline $\mathrm{Cm}-244$ & $2.716 \mathrm{E}+04$ \\
\hline Co-60 & $7.229 \mathrm{E}+06$ \\
\hline Cs-137 & $1.955 \mathrm{E}+06$ \\
\hline Eu-152 & $1.324 \mathrm{E}+07$ \\
\hline Eu-154 & $9.741 \mathrm{E}+06$ \\
\hline Eu-155 & $6.645 \mathrm{E}+07$ \\
\hline $\mathrm{Nb}-94$ & $3.966 \mathrm{E}+07$ \\
\hline $\mathrm{Pu}-238$ & $1.388 \mathrm{E}+04$ \\
\hline $\mathrm{Pu}-239 / 240$ & $1.268 \mathrm{E}+04$ \\
\hline Sr-90 & $8.075 \mathrm{E}+05$ \\
\hline Th-232 & $1.341 \mathrm{E}+04$ \\
\hline U-234 & $1.379 \mathrm{E}+05$ \\
\hline U-235 & $1.496 \mathrm{E}+05$ \\
\hline $\mathrm{U}-238$ & $1.554 \mathrm{E}+05$ \\
\hline
\end{tabular}

A soil sample at this RRMG value would present an internal dose potential of 25 mrem under the Remote Work Area exposure scenario. 
Table 5: Soils Project - Remote Work Area Exposure Scenario - Internal \& External Dose

\begin{tabular}{|c|c|}
\hline Radionuclide & $\begin{array}{c}\text { RRMG } \\
(\mathbf{p C i} / \mathrm{g})\end{array}$ \\
\hline Ag-108m $)$ & $6.204 \mathrm{E}+02$ \\
\hline Am-241 & $9.239 \mathrm{E}+03$ \\
\hline Cm-243 & $2.083 \mathrm{E}+03$ \\
\hline Cm-244 & $2.715 \mathrm{E}+04$ \\
\hline Co-60 & $1.225 \mathrm{E}+02$ \\
\hline Cs-137 & $4.874 \mathrm{E}+02$ \\
\hline Eu-152 & $2.557 \mathrm{E}+02$ \\
\hline Eu-154 & $2.387 \mathrm{E}+02$ \\
\hline Eu-155 & $6.406 \mathrm{E}+03$ \\
\hline $\mathrm{Nb}-94$ & $6.452 \mathrm{E}+02$ \\
\hline Pu-238 & $1.390 \mathrm{E}+04$ \\
\hline Pu-239/240 & $1.269 \mathrm{E}+04$ \\
\hline Sr-90 & $5.522 \mathrm{E}+04$ \\
\hline Th-232 & $3.292 \mathrm{E}+03$ \\
\hline $\mathrm{U}-234$ & $1.314 \mathrm{E}+05$ \\
\hline $\mathrm{U}-235$ & $1.709 \mathrm{E}+03$ \\
\hline $\mathrm{U}-238$ & $9.572 \mathrm{E}+03$ \\
\hline & \\
\hline
\end{tabular}

A soil sample at this RRMG value would present a TED potential of 25 mrem under the Remote Work Area exposure scenario. 
Table 6: Soils Project - Occasional Use Area Exposure Scenario - Internal Dose Only

\begin{tabular}{|c|c|}
\hline Radionuclide & $\begin{array}{c}\mathbf{R R M G}_{(\text {OUA-I })} \\
(\mathrm{pCi} / \mathrm{g})\end{array}$ \\
\hline Ag-108m & $2.762 \mathrm{E}+08$ \\
\hline Am-241 & $4.555 \mathrm{E}+04$ \\
\hline $\mathrm{Cm}-243$ & $6.307 \mathrm{E}+04$ \\
\hline $\mathrm{Cm}-244$ & $7.68 \mathrm{E}+04$ \\
\hline Co-60 & $7.421 \mathrm{E}+07$ \\
\hline Cs-137 & $2.756 \mathrm{E}+07$ \\
\hline Eu-152 & $8.174 \mathrm{E}+07$ \\
\hline Eu-154 & $6.353 \mathrm{E}+07$ \\
\hline Eu-155 & $4.751 \mathrm{E}+08$ \\
\hline $\mathrm{Nb}-94$ & $2.492 \mathrm{E}+08$ \\
\hline $\mathrm{Pu}-238$ & $3.922 \mathrm{E}+04$ \\
\hline $\mathrm{Pu}-239 / 240$ & $3.582 \mathrm{E}+04$ \\
\hline Sr-90 & $9.949 \mathrm{E}+06$ \\
\hline Th-232 & $3.852 \mathrm{E}+04$ \\
\hline U-234 & $4.470 \mathrm{E}+05$ \\
\hline U-235 & $4.922 \mathrm{E}+05$ \\
\hline $\mathrm{U}-238$ & $3.361 \mathrm{E}+05$ \\
\hline
\end{tabular}

A soil sample at this RRMG value would present an internal dose potential of 25 mrem under the Occasional Use Area exposure scenario. 
Table 7: Soils Project - Occasional Use Area Exposure Scenario - Internal \& External Dose

\begin{tabular}{|c|c|}
\hline Radionuclide & $\begin{array}{c}\mathbf{R R M G}_{(\text {OUA-IE })} \\
(\mathrm{pCi} / \mathrm{g})\end{array}$ \\
\hline Ag-108m & $2.087 \mathrm{E}+03$ \\
\hline Am-241 & $2.797 \mathrm{E}+04$ \\
\hline $\mathrm{Cm}-243$ & $6.886 \mathrm{E}+03$ \\
\hline $\mathrm{Cm}-244$ & $7.653 \mathrm{E}+04$ \\
\hline Co-60 & $4.122 \mathrm{E}+02$ \\
\hline Cs-137 & $1.640 \mathrm{E}+03$ \\
\hline Eu-152 & $8.604 \mathrm{E}+02$ \\
\hline Eu-154 & $8.031 \mathrm{E}+02$ \\
\hline Eu-155 & $2.156 \mathrm{E}+04$ \\
\hline $\mathrm{Nb}-94$ & $2.171 \mathrm{E}+03$ \\
\hline $\mathrm{Pu}-238$ & $3.915 \mathrm{E}+04$ \\
\hline $\mathrm{Pu}-239 / 240$ & $3.573 \mathrm{E}+04$ \\
\hline Sr-90 & $1.955 \mathrm{E}+05$ \\
\hline Th-232 & $1.062 \mathrm{E}+04$ \\
\hline U-234 & $4.252 \mathrm{E}+05$ \\
\hline U-235 & $5.749 \mathrm{E}+03$ \\
\hline $\mathrm{U}-238$ & $3.219 \mathrm{E}+04$ \\
\hline
\end{tabular}

A soil sample at this RRMG value would present a TED potential of 25 mrem under the Occasional Use Area exposure scenario. 


\section{References}

CFR, see Code of Federal Regulations.

Code of Federal Regulations. 2011. Title 10 CFR Part 835, “Occupational Radiation Protection.” Washington, DC: U.S. Government Printing Office.

DOE, see U.S. Department of Energy.

NNSA/NSO, see U.S. Department of Energy, National Nuclear Security Administration Nevada Site Office.

U.S. Department of Energy. 2011. Radiation Protection of the Public and the Environment, DOE Order 458.1, Change 2. Washington, DC: Office of Health, Safety, and Security.

U.S. Department of Energy, National Nuclear Security Administration Nevada Site Office. 2006. Industrial Sites Project Establishment of Final Action Levels, Rev. 0, DOE/NV--1107. Las Vegas, NV.

Yu, C., A.J. Zielen, J.J. Cheng, D.J. LePoire, E. Gnanapragasam, S. Kamboj, J. Arnish, A. Wallo III, W.A. Williams, and H. Peterson. 2001. User's Manual for RESRAD Version 6, ANL/EAD-4. Argonne, IL: Argonne National Laboratory, Environmental Assessment Division. (Version 6.5 released in October 2009.) 


\section{APPENDIX B}

\section{WASTE DISPOSITION DOCUMENTATION}


CAU 366 Closure Report

Section: Appendix B

Revision: 0

Date: December 2013

\section{THIS PAGE INTENTIONALLY LEFT BLANK}


NSTec

Form

CERTIFICATE OF DISPOSAL

$03 / 01 / 10$

FRM-2217

(LOW LEVEL WASTE)

Rev. 01

Page 1 of 1

\section{Nevada Test Site}

This Certificate acknowledges that the following shipment(s) of waste have been disposed at the Nevada Test Site Radioactive Waste Management Complex.

\begin{tabular}{|l|l|l|l|}
\hline Shipment Number & $\begin{array}{c}\text { Waste Stream } \\
\text { Identification \# }\end{array}$ & Package \# & Date of Disposal \\
\hline DPL13017 & LRY5LLFY99020 & INTERMODAL \#000001-1 PKG\# 13L037 & $8 / 7 / 3$ \\
\hline & & & \\
\hline & & & \\
\hline & & & \\
\hline & & & \\
\hline & & & \\
\hline & & & \\
\hline
\end{tabular}

This certification is provided as a courtesy to the waste generator for information purposes only.

/s/: Robert H. Zion

WGS Signature

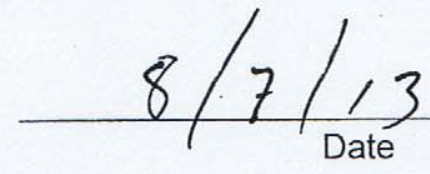

WASTE INSPECTOR

Title

Is/: Jon Tanaka

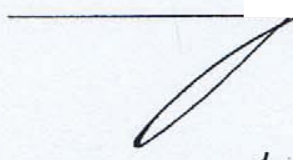

RWWMC Signature
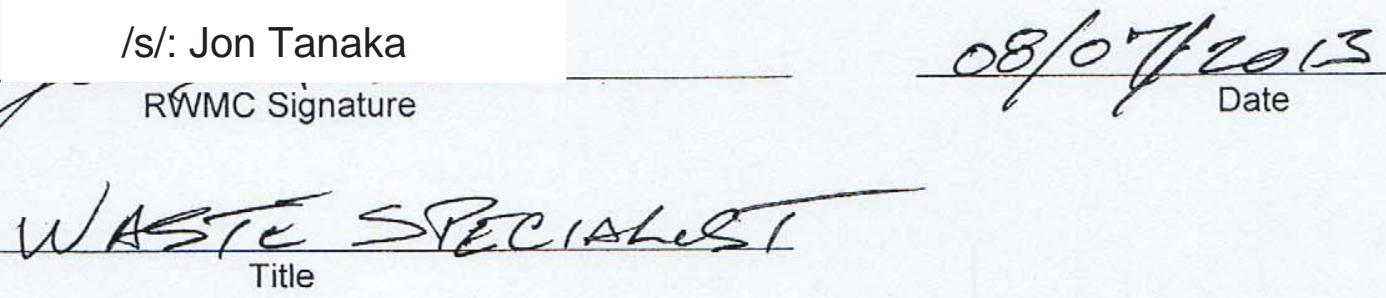
CAU 366 Closure Report

Section: Appendix B

Revision: 0

Date: December 2013

\section{THIS PAGE INTENTIONALLY LEFT BLANK}


CAU 366 Closure Report

Section: Appendix C

Revision: 0

Date: December 2013

\section{APPENDIX C}

\section{SITE CLOSURE PHOTOGRAPHS}


CAU 366 Closure Report

Section: Appendix C

Revision: 0

Date: December 2013

\section{THIS PAGE INTENTIONALLY LEFT BLANK}


PhOTOGRAPH LOG

\begin{tabular}{|c|c|c|}
\hline $\begin{array}{l}\text { PHOTOGRAPH } \\
\text { NUMBER }\end{array}$ & DATE & DESCRIPTION \\
\hline 1 & $11 / 27 / 2012$ & CAS 11-08-01, CWD \#1, before Closure Activities \\
\hline 2 & $11 / 27 / 2012$ & CAS 11-08-02, CWD \#2, before Closure Activities \\
\hline 3 & $03 / 26 / 2013$ & Placing Clean Fill in the Buffer Area at CAS 11-08-01, CWD \#1 \\
\hline 4 & $03 / 27 / 2013$ & Survey Stakes at CAS 11-08-01, CWD \#1 \\
\hline 5 & $03 / 28 / 2013$ & Construction of the Cover at CAS 11-08-01, CWD \#1 \\
\hline 6 & $04 / 01 / 2013$ & Construction of the Cover at CAS 11-08-01, CWD \#1 \\
\hline 7 & $04 / 09 / 2013$ & Construction of the Cover at CAS 11-08-01, CWD \#1 \\
\hline 8 & $04 / 10 / 2013$ & Construction of the Cover at CAS 11-08-01, CWD \#1 \\
\hline 9 & $04 / 10 / 2013$ & Survey Stakes at CAS 11-08-02, CWD \#2 \\
\hline 10 & $04 / 11 / 2013$ & Construction of the Cover at CAS 11-08-01, CWD \#1 \\
\hline 11 & $04 / 15 / 2013$ & Survey Stakes at CAS 11-08-01, CWD \#1 \\
\hline 12 & $04 / 16 / 2013$ & Radiological Surveys to Downpost CAS 11-08-02, CWD \#2 \\
\hline 13 & $04 / 16 / 2013$ & Placing Clean Fill in the Buffer Area at CAS 11-08-02, CWD \#2 \\
\hline 14 & $04 / 16 / 2013$ & Clean Fill on the Access Road to CAS 11-08-02, CWD \#2 \\
\hline 15 & $04 / 18 / 2013$ & Construction of the Cover at CAS 11-08-02, CWD \#2 \\
\hline 16 & $04 / 22 / 2013$ & Construction of the Cover at CAS 11-08-02, CWD \#2 \\
\hline 17 & $04 / 23 / 2013$ & Final Grading of the Cover at CAS 11-08-01, CWD \#1 \\
\hline 18 & $04 / 29 / 2013$ & Construction of the Cover at CAS 11-08-02, CWD \#2 \\
\hline 19 & $05 / 02 / 2013$ & Construction of the Cover at CAS 11-08-02, CWD \#2 \\
\hline 20 & $05 / 14 / 2013$ & Placement of Concrete Monuments at CAS 11-08-01, CWD \#1 \\
\hline 21 & $05 / 29 / 2013$ & Use Restriction Warning Signs at the Gate on the Road Leading to the Site \\
\hline 22 & $05 / 29 / 2013$ & Use Restriction Warning Signs on Contamination Area Fence \\
\hline 23 & $05 / 30 / 2013$ & Radiological Postings at CAS 11-08-01, CWD \#1 \\
\hline 24 & $06 / 10 / 2013$ & $\begin{array}{l}\text { Use Restriction Warning Signs on Concrete Monument at CAS 11-08-01, } \\
\text { CWD \#1 }\end{array}$ \\
\hline
\end{tabular}


CAU 366 Closure Report

Section: Appendix C

Revision: 0

Date: December 2013

\section{THIS PAGE INTENTIONALLY LEFT BLANK}




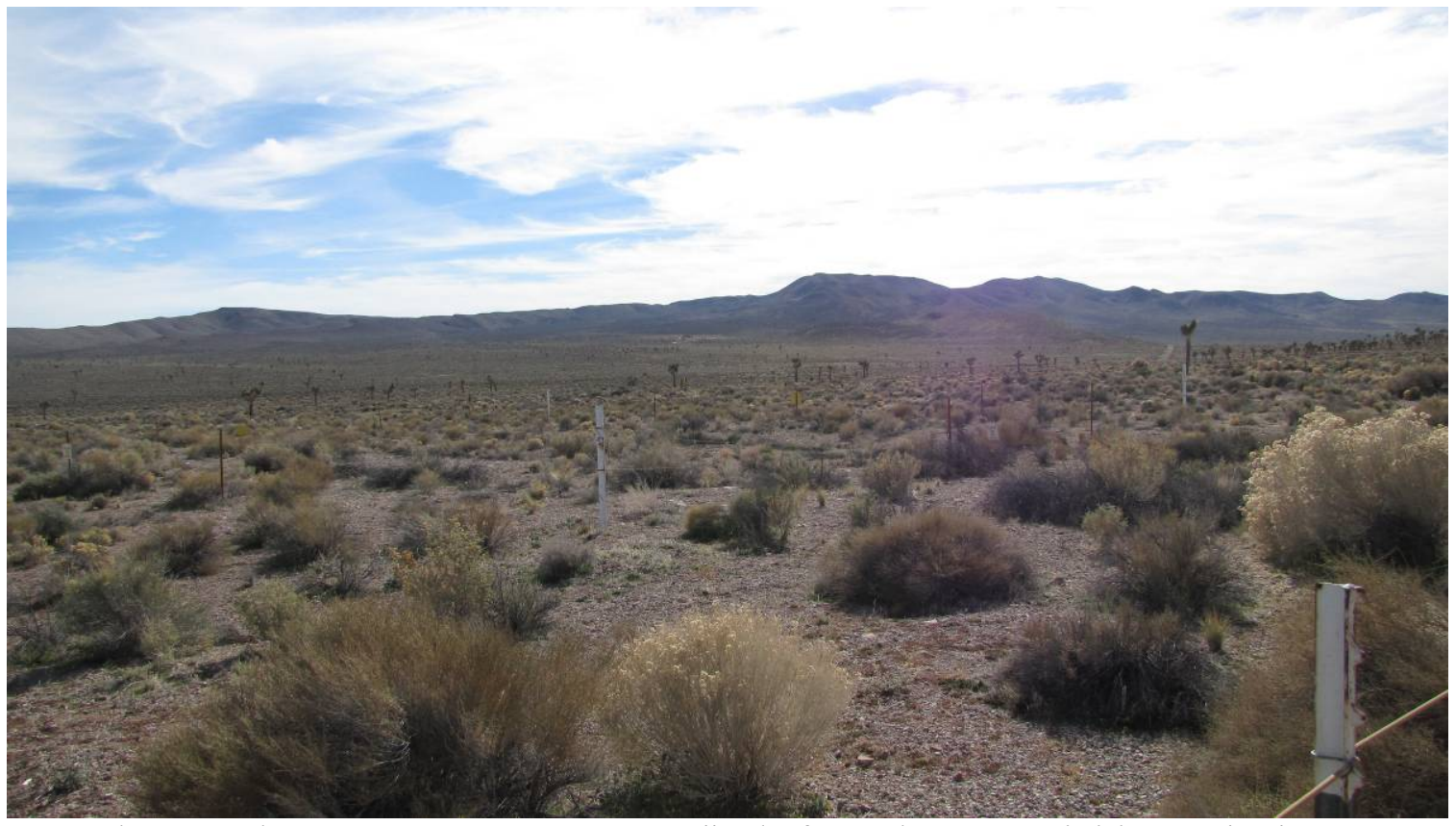

Photograph 1: CAS 11-08-01, CWD \#1, before Closure Activities, 11/27/2012

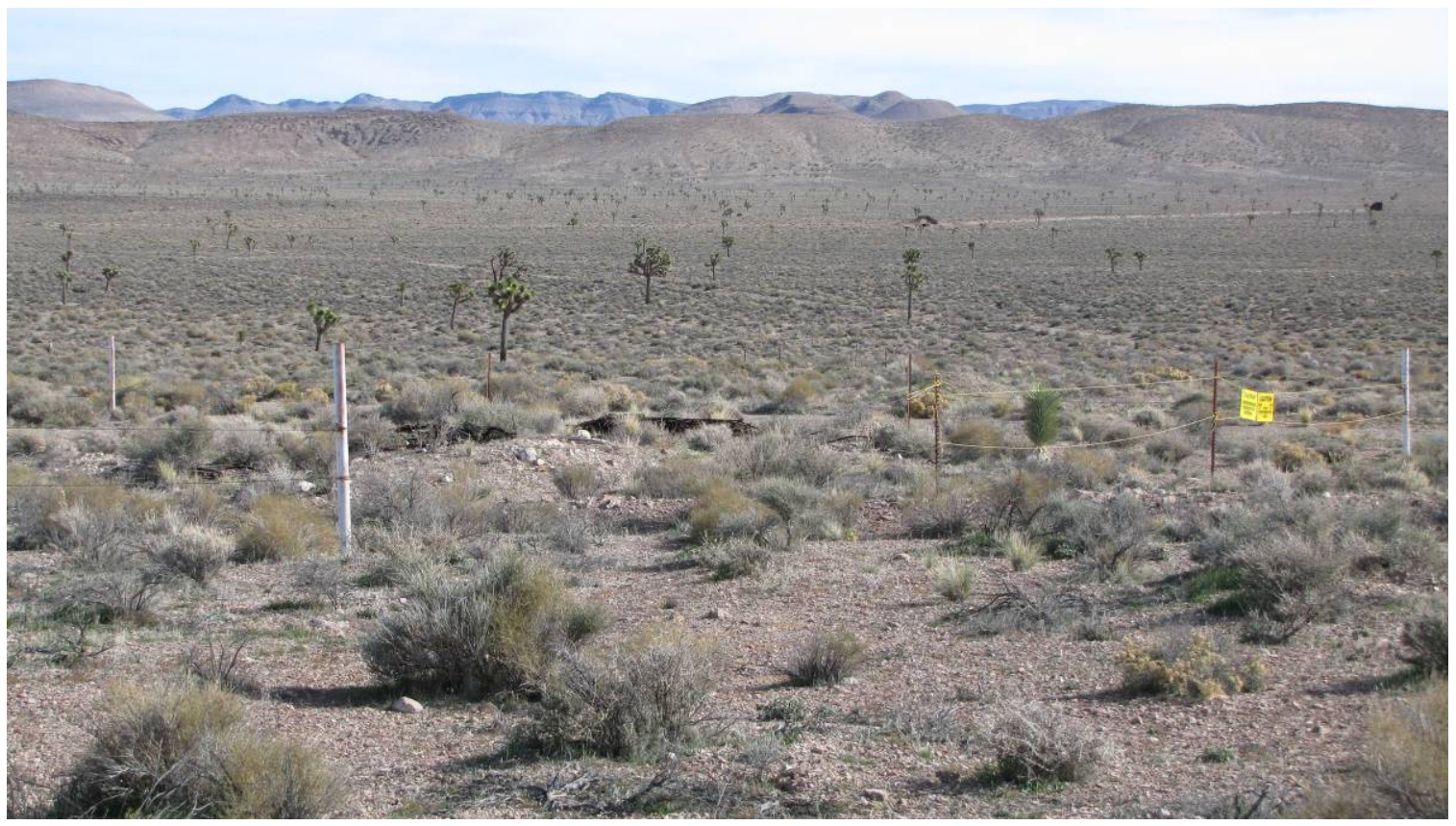

Photograph 2: CAS 11-08-02, CWD \#2, before Closure Activities, 11/27/2012 


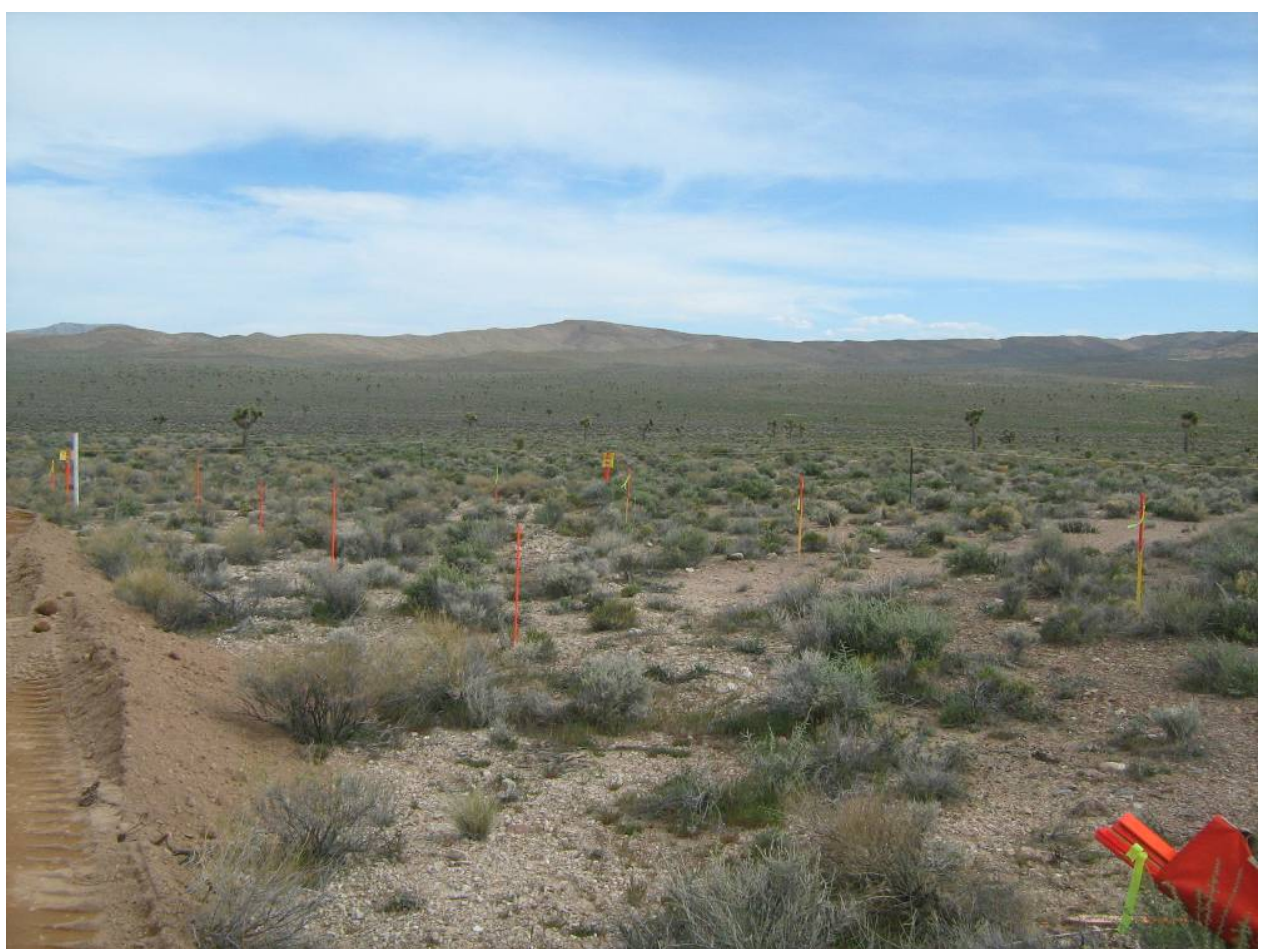

Photograph 4: Survey Stakes at CAS 11-08-01, CWD \#1, 03/27/2013 


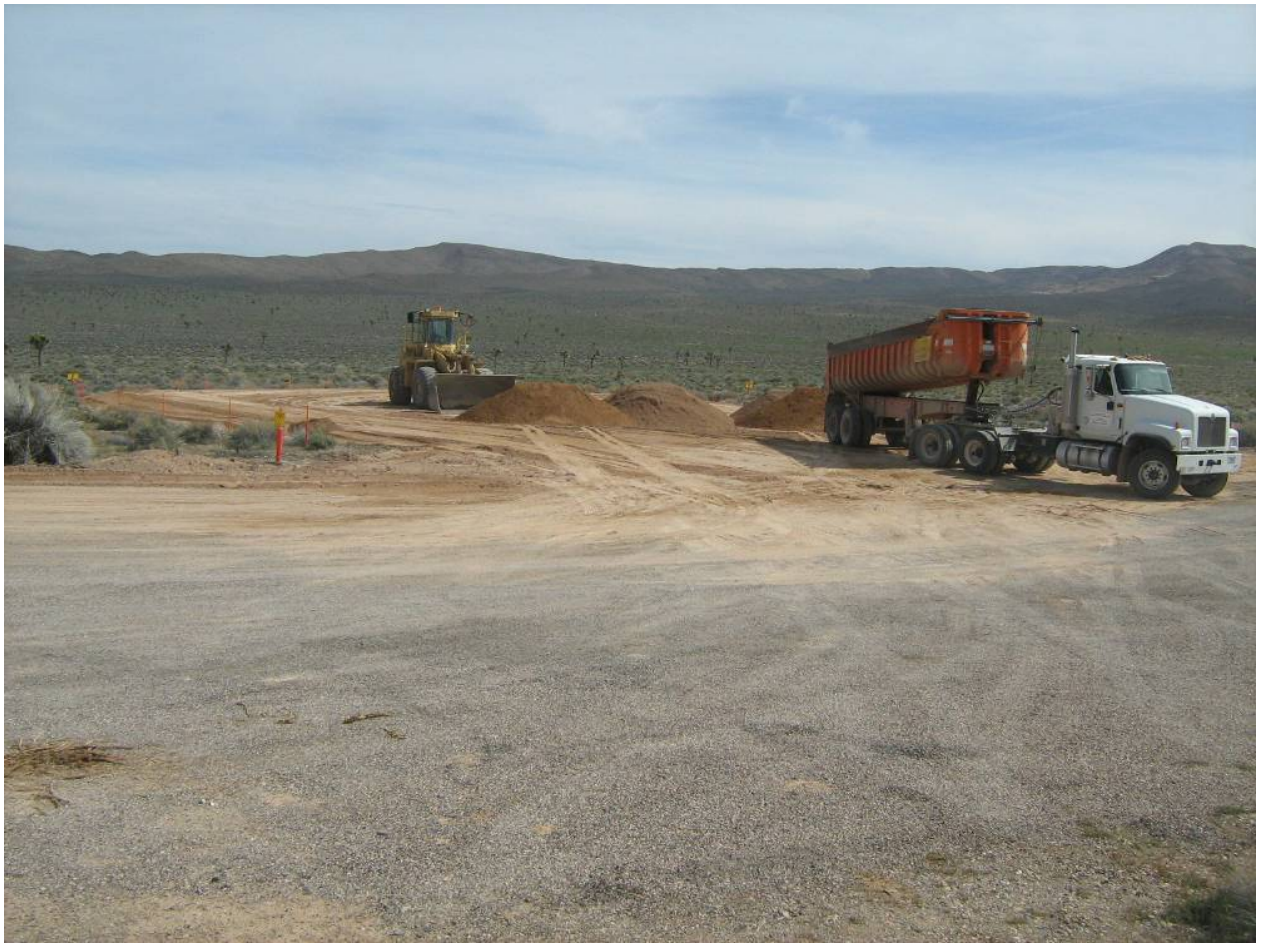

Photograph 5: Construction of the Cover at CAS 11-08-01, CWD \#1, 03/28/2013

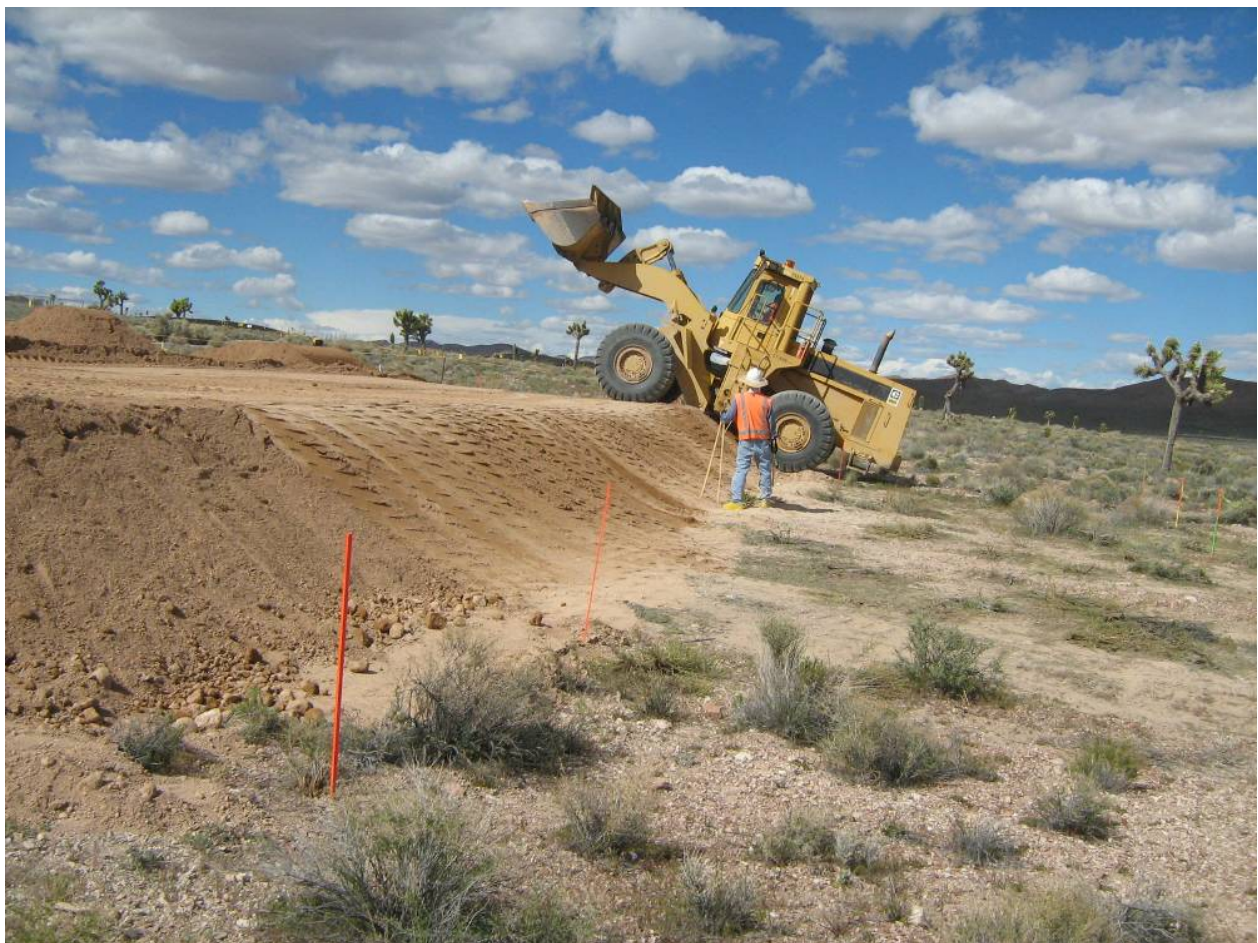

Photograph 6: Construction of the Cover at CAS 11-08-01, CWD \#1, 04/01/2013 


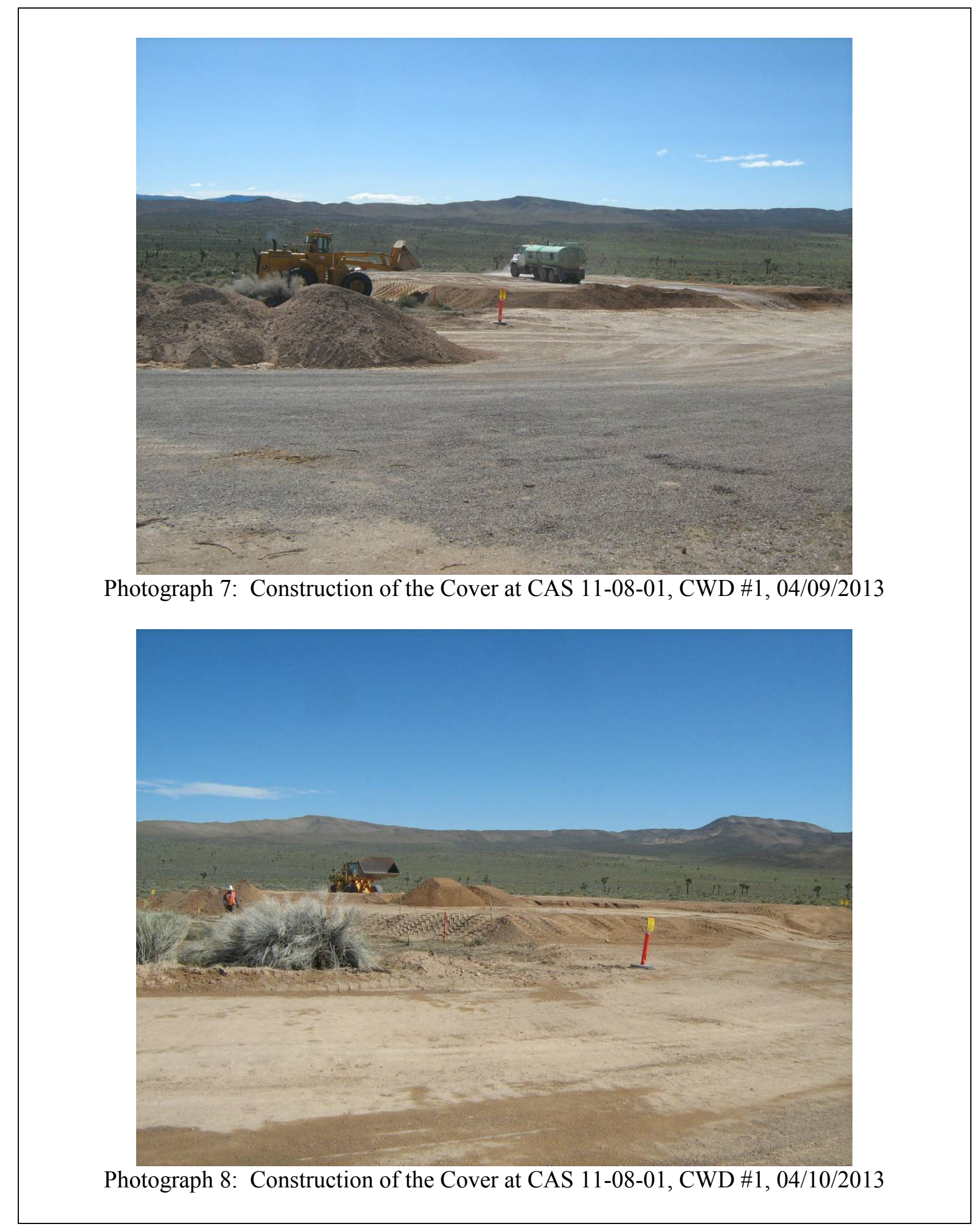




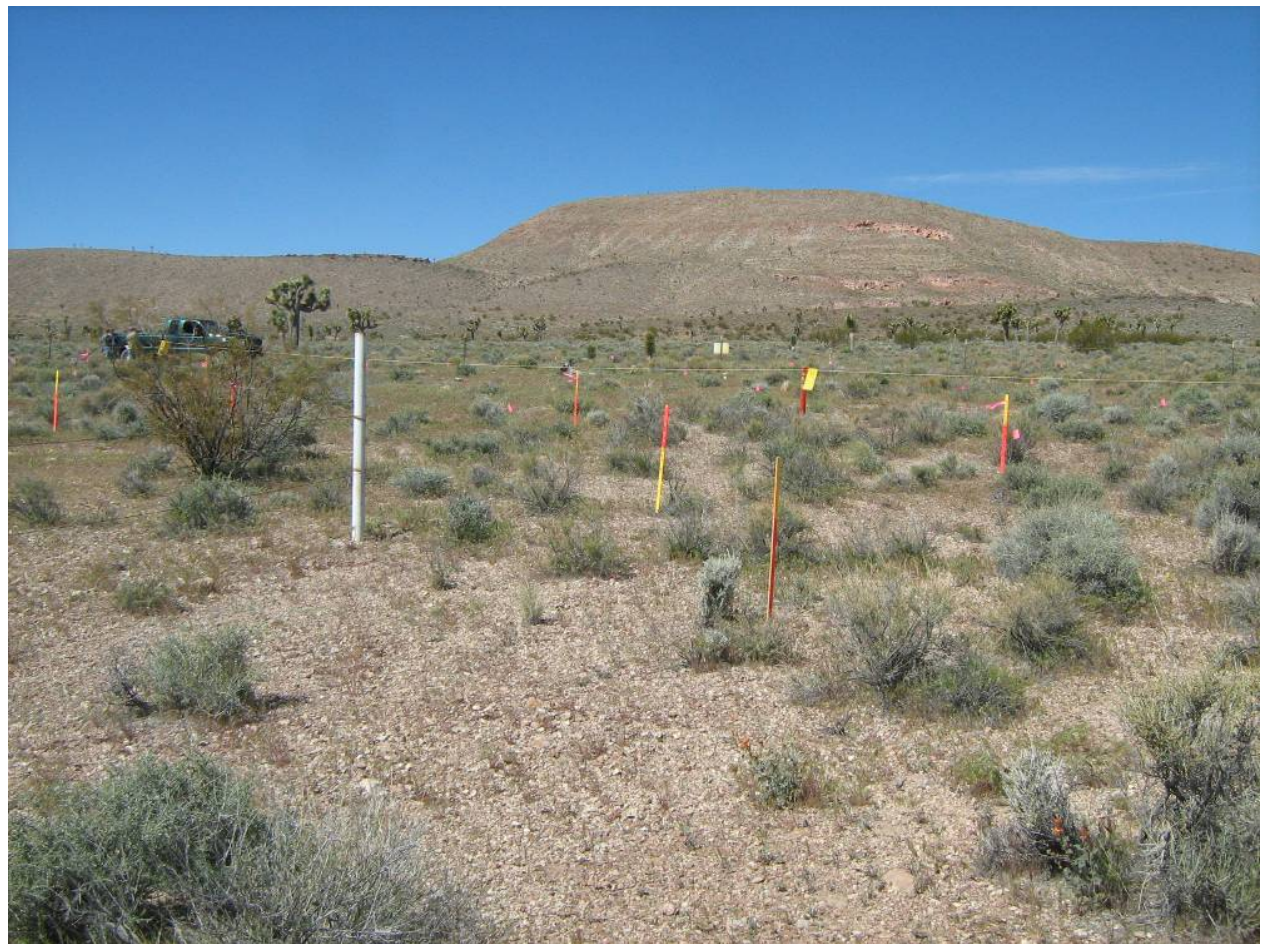

Photograph 9: Survey Stakes at CAS 11-08-02, CWD \#2, 04/10/2013

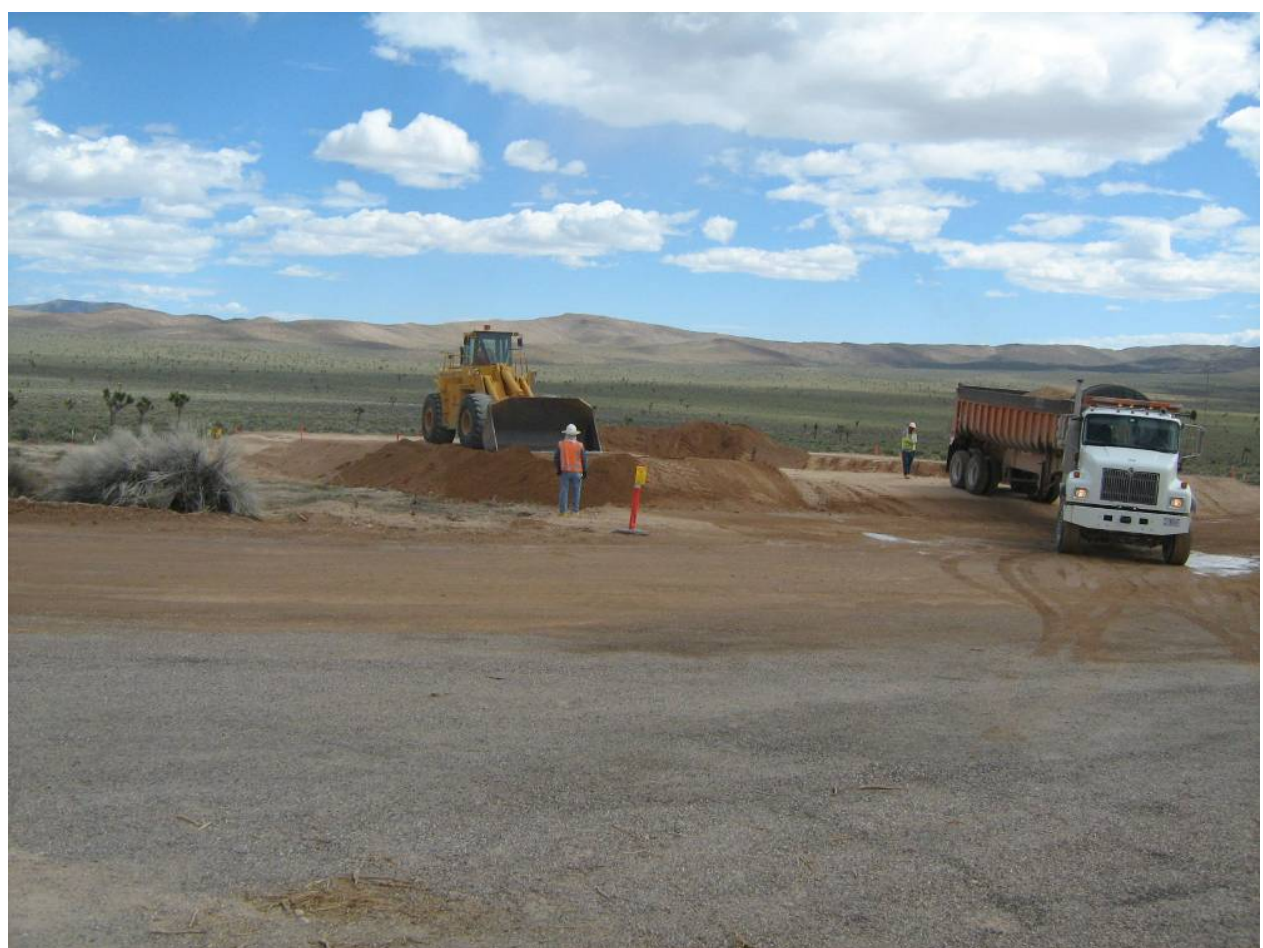

Photograph 10: Construction of the Cover at CAS 11-08-01, CWD \#1, 04/11/2013 


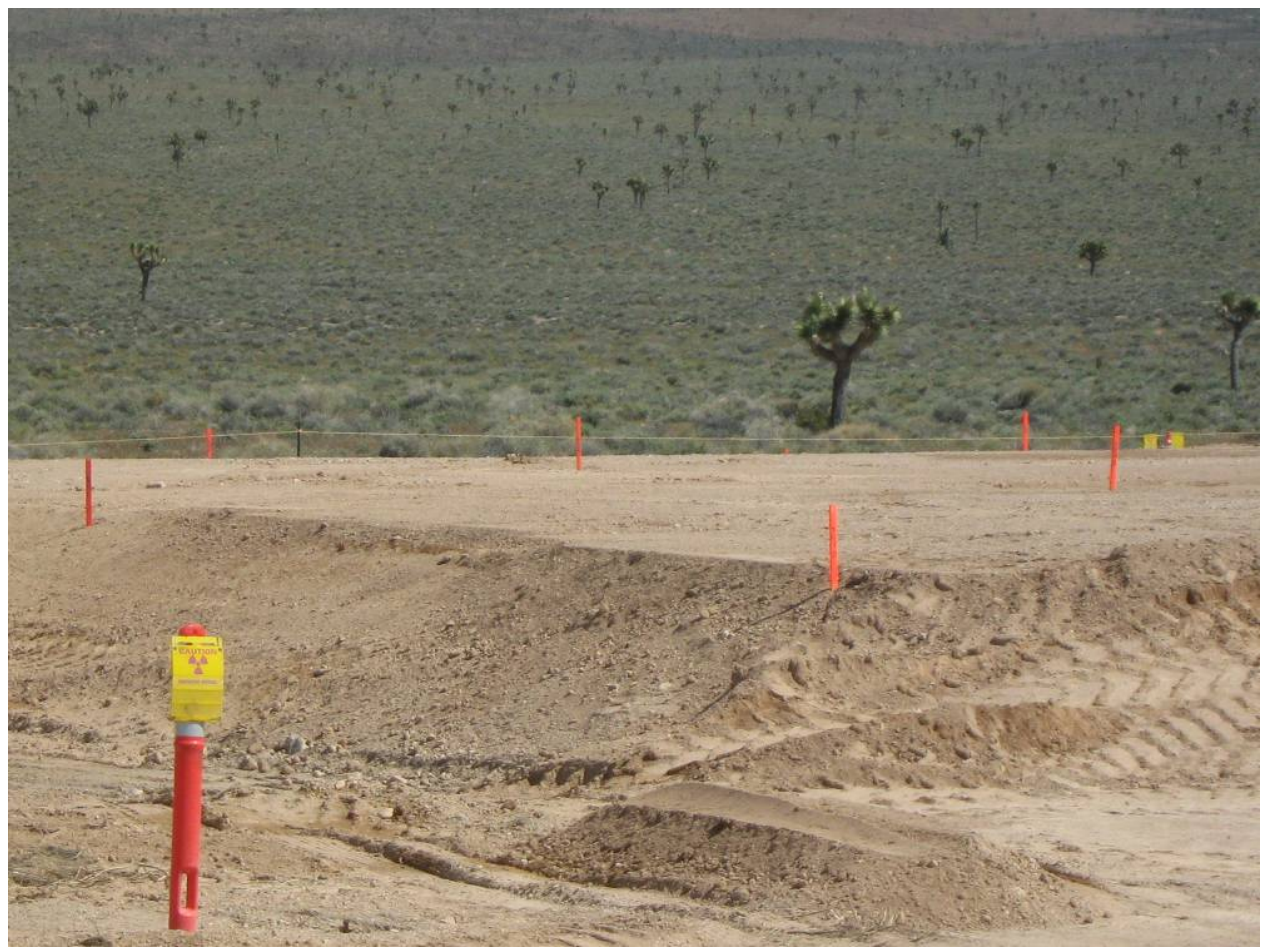

Photograph 11: Survey Stakes at CAS 11-08-01, CWD \#1, 04/15/2013

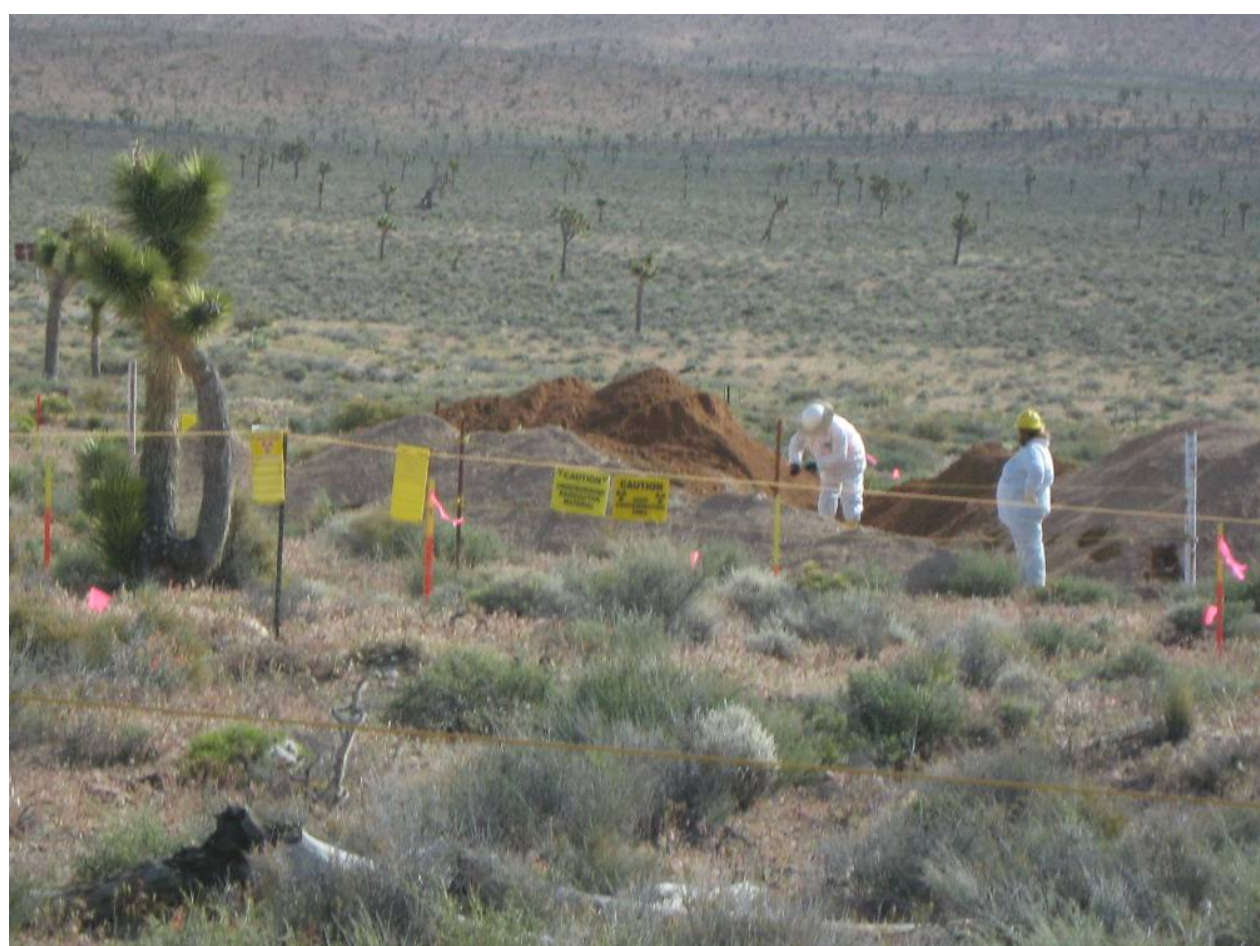

Photograph 12: Radiological Surveys to Downpost CAS 11-08-02, CWD \#2, 04/16/2013 


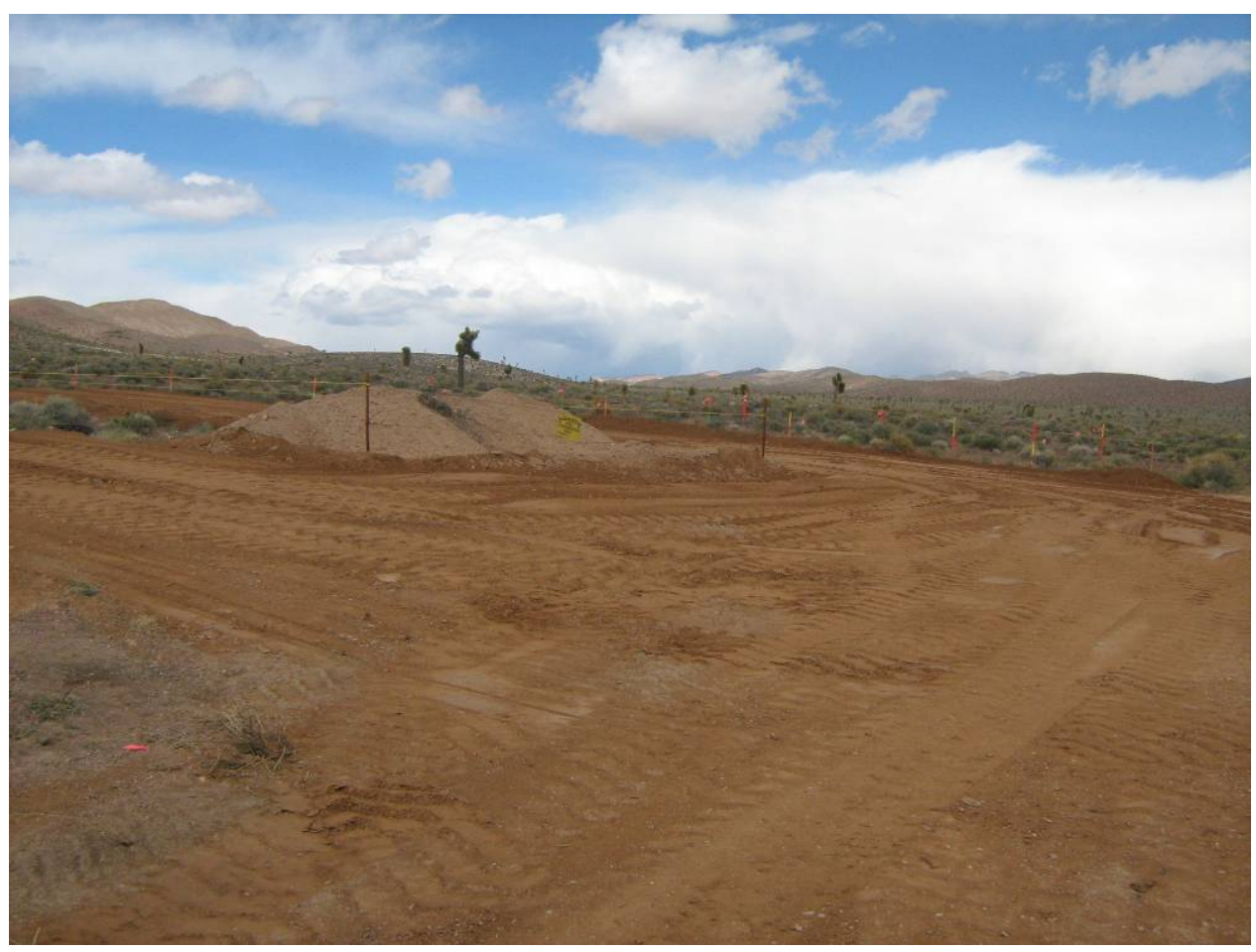

Photograph 13: Placing Clean Fill in the Buffer Area at CAS 11-08-02, CWD \#2, 04/16/2013

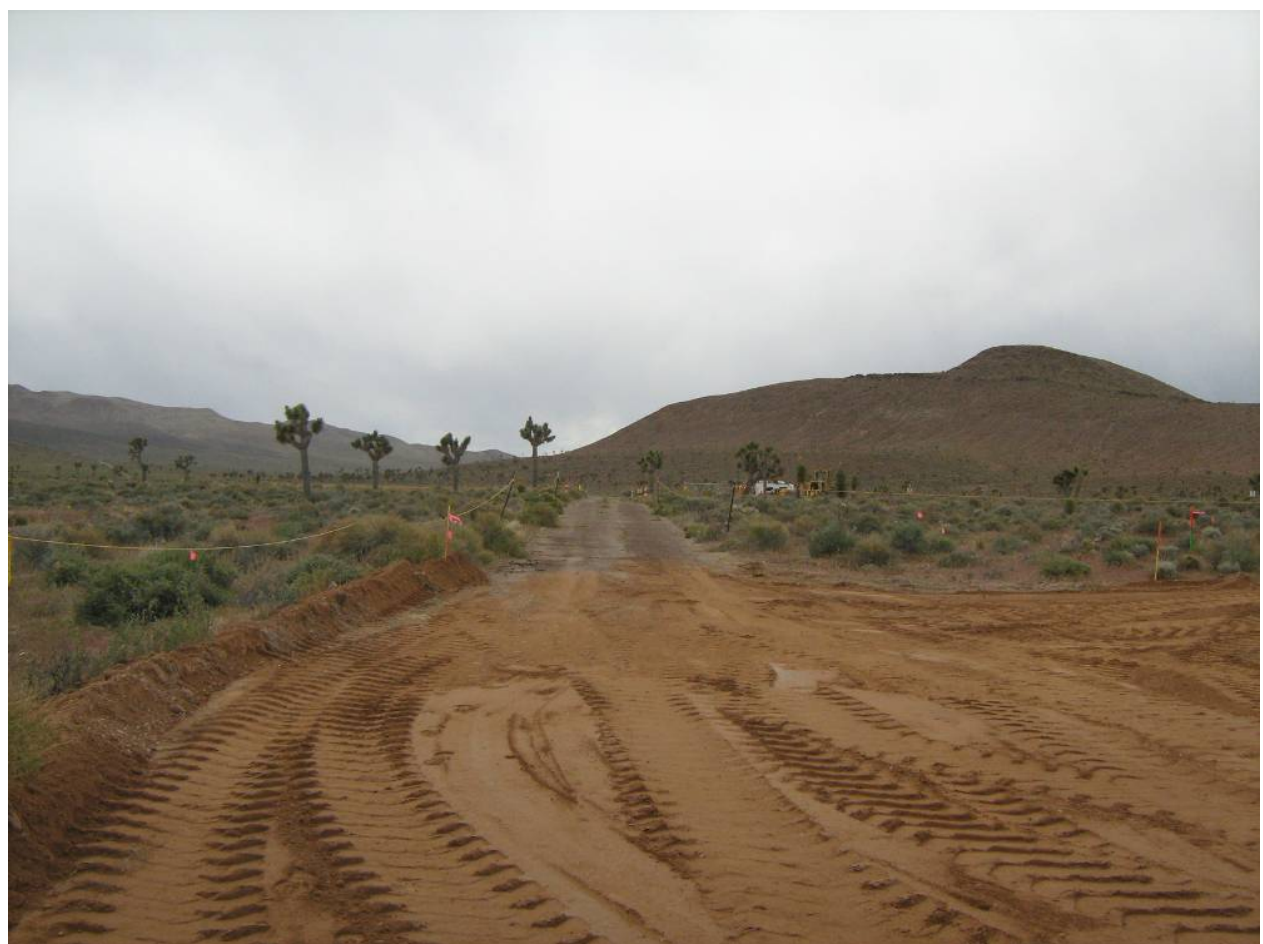

Photograph 14: Clean Fill on the Access Road to CAS 11-08-02, CWD \#2, 04/16/2013 


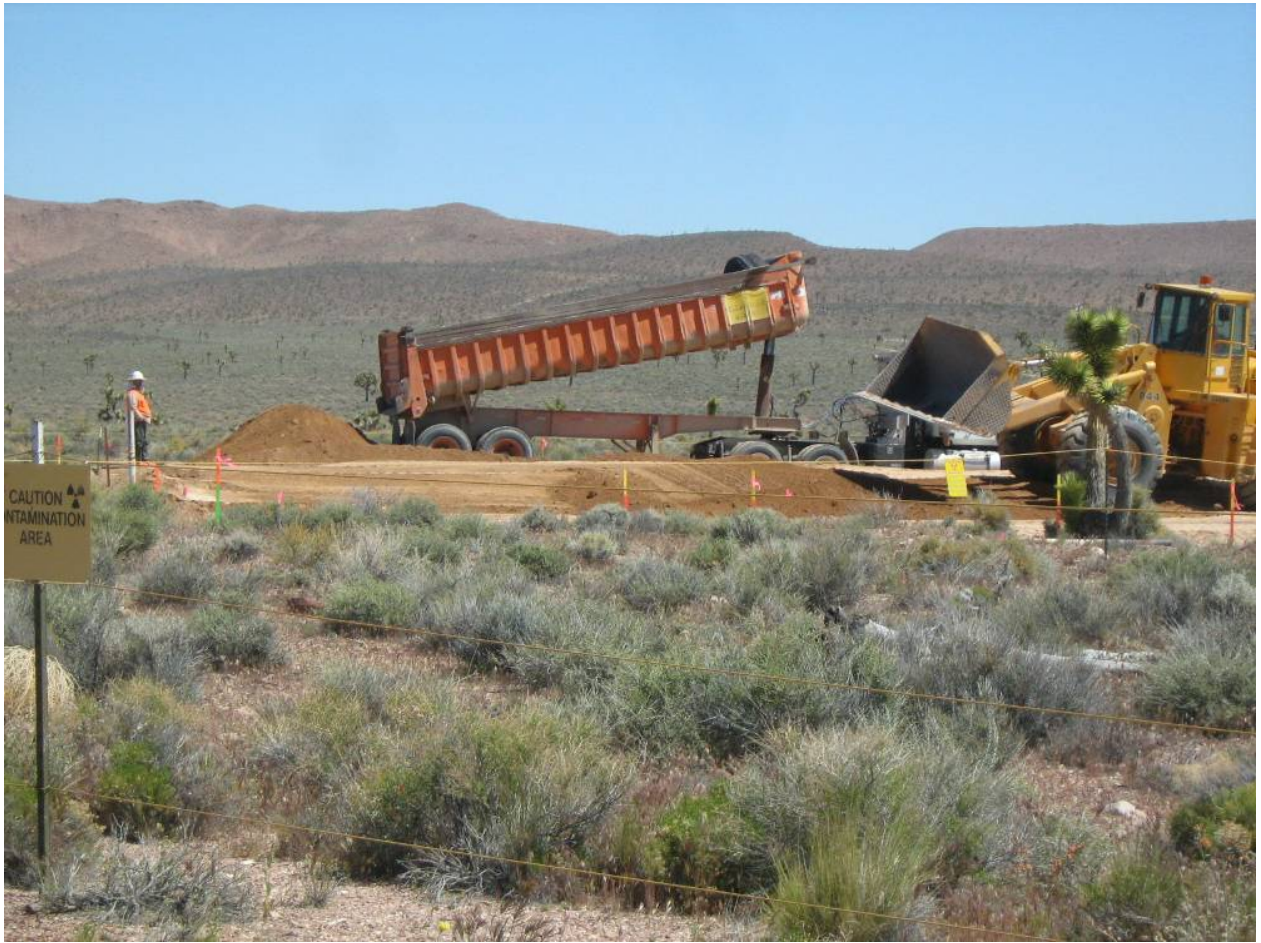

Photograph 15: Construction of the Cover at CAS 11-08-02, CWD \#2, 04/18/2013

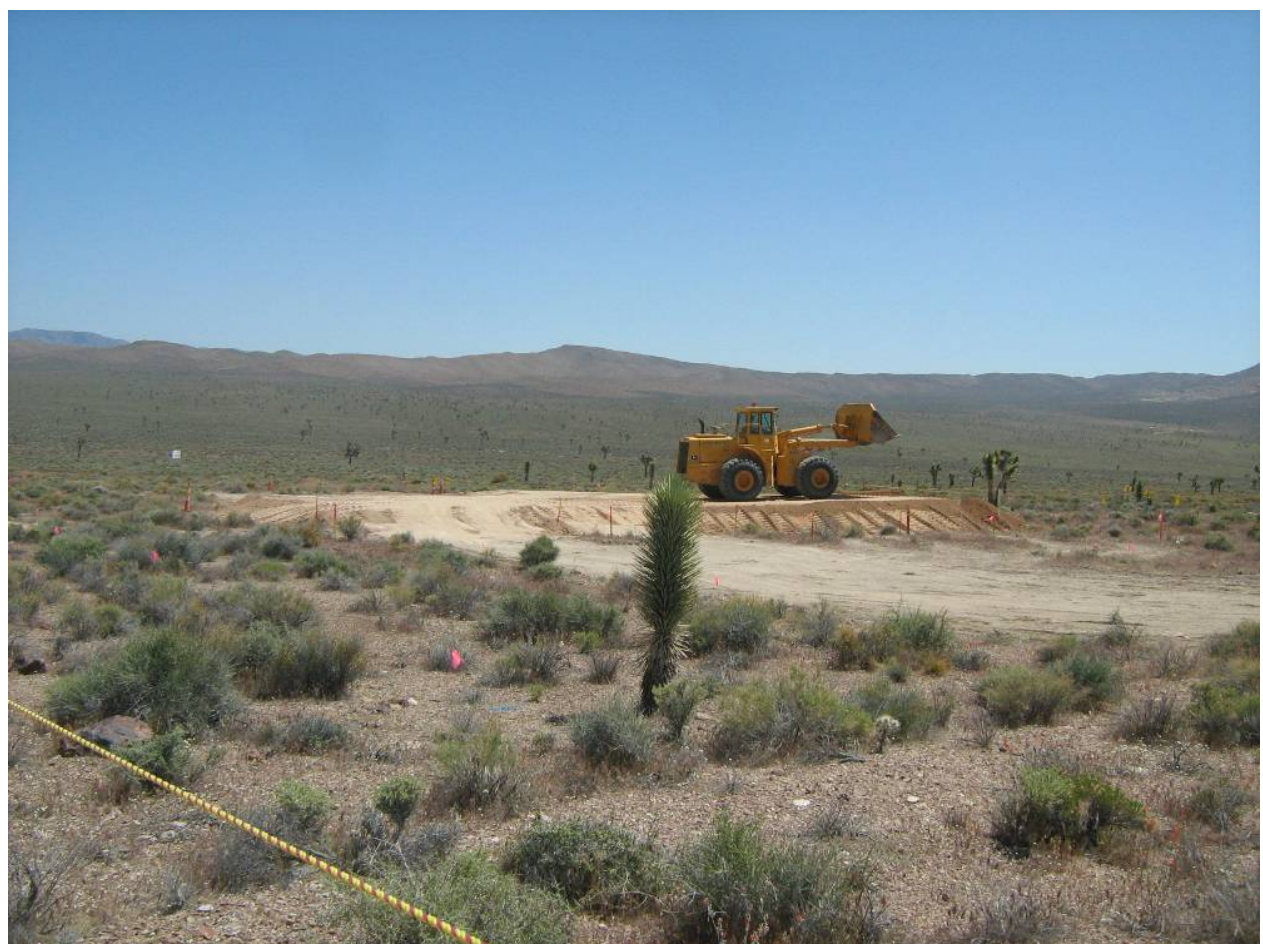

Photograph 16: Construction of the Cover at CAS 11-08-02, CWD \#2, 04/22/2013 


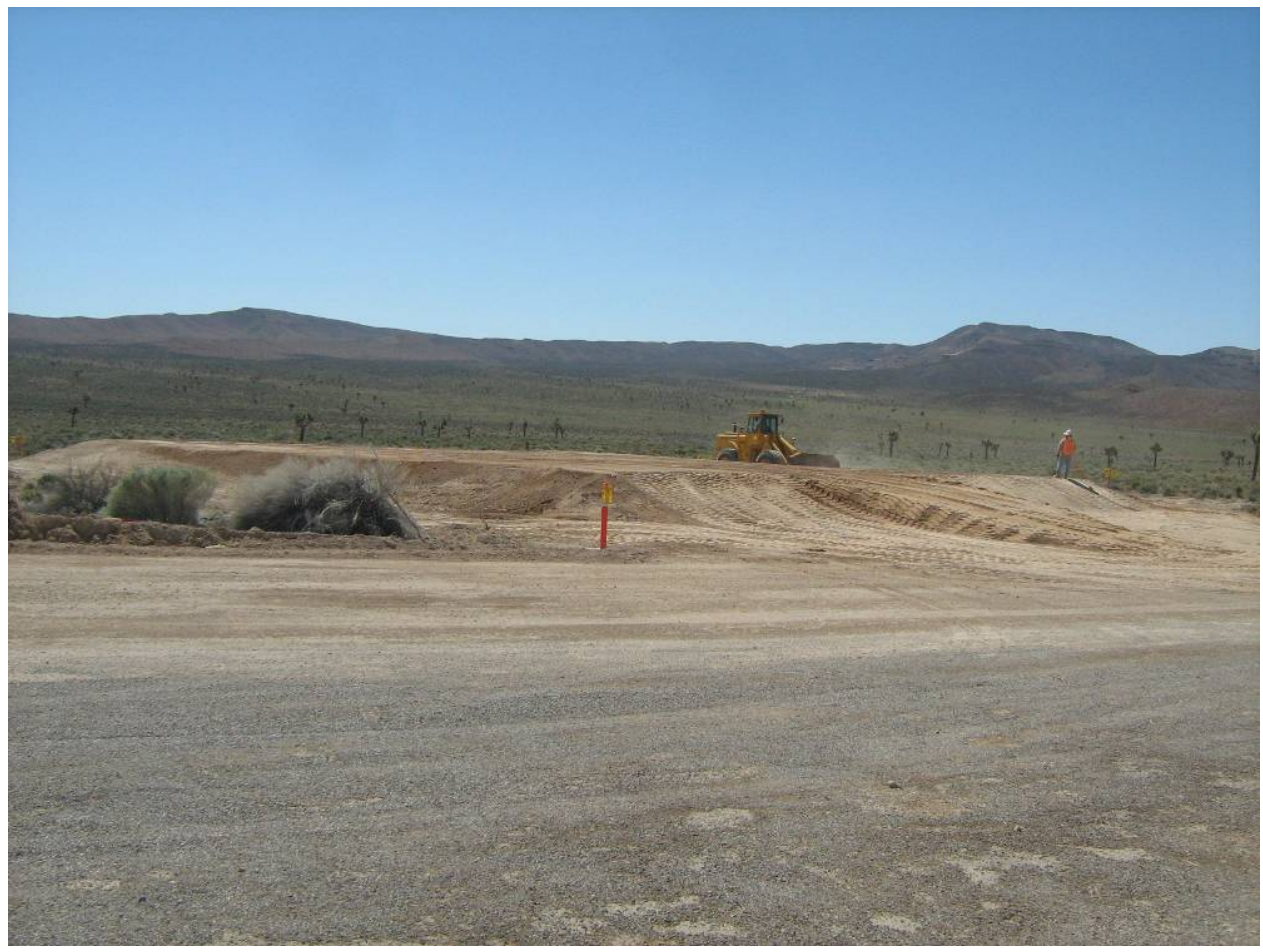

Photograph 17: Final Grading of the Cover at CAS 11-08-01, CWD \#1, 04/23/2013

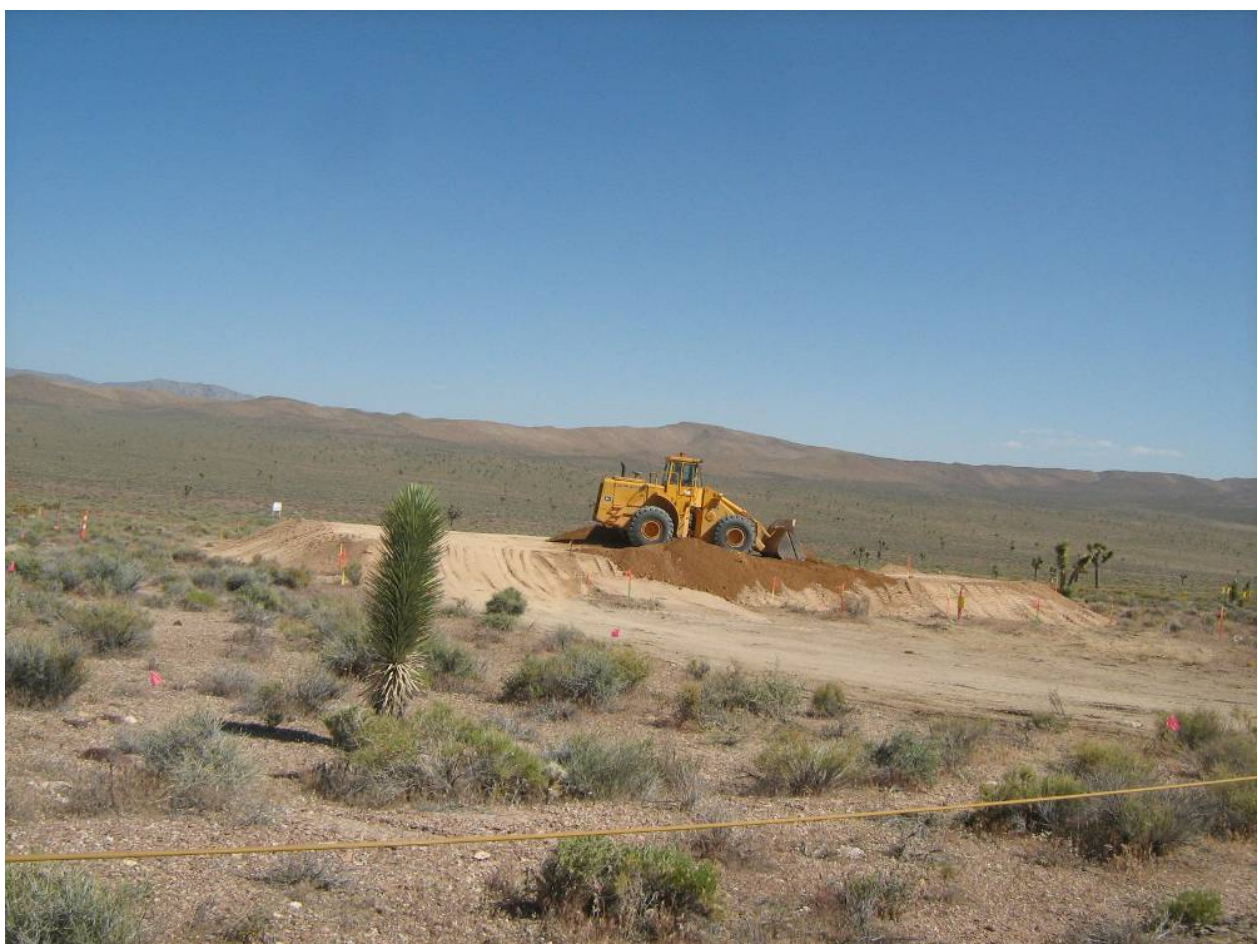

Photograph 18: Construction of the Cover at CAS 11-08-02, CWD \#2, 04/29/2013 


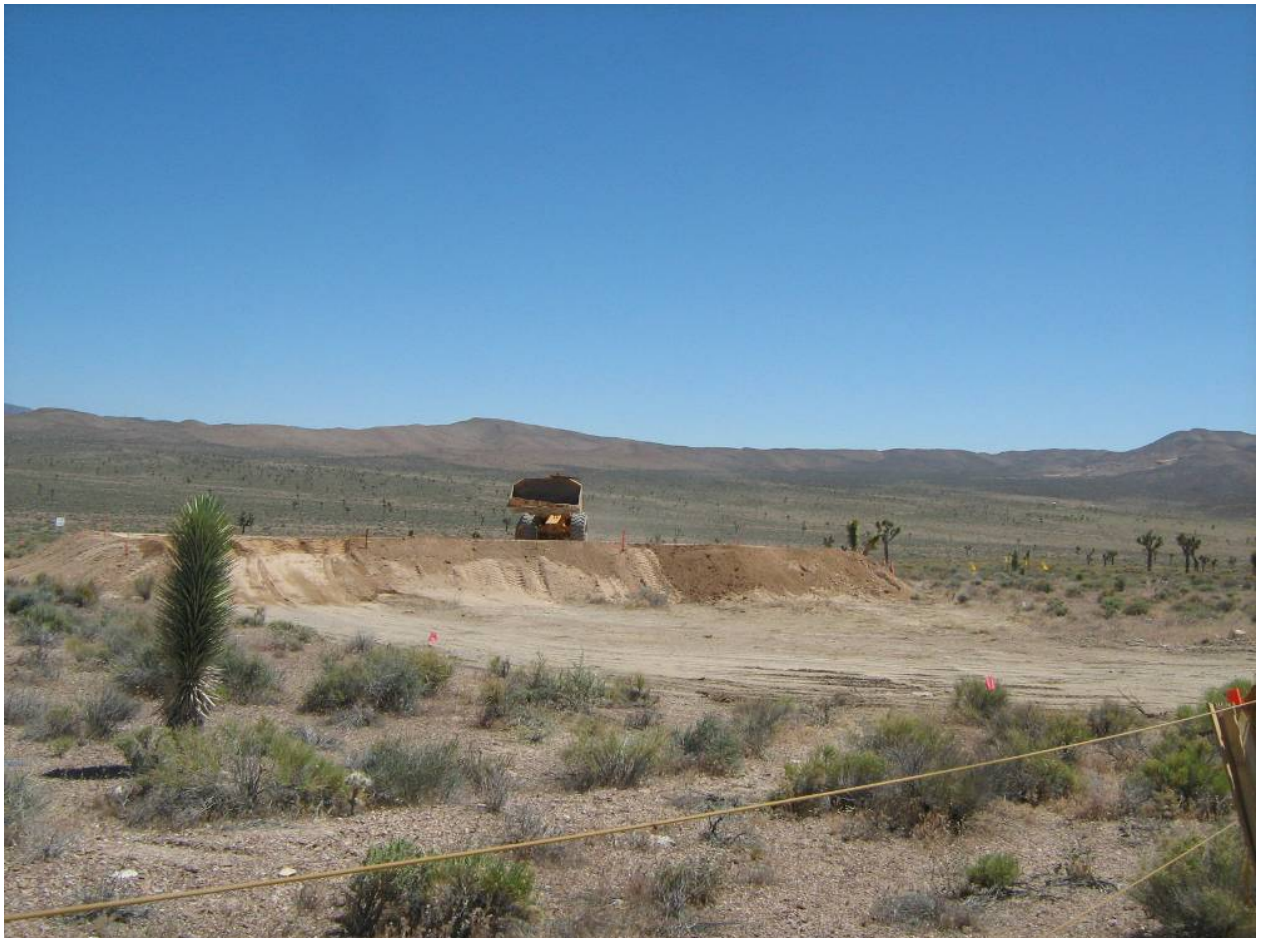

Photograph 19: Construction of the Cover at CAS 11-08-02, CWD \#2, 05/02/2013

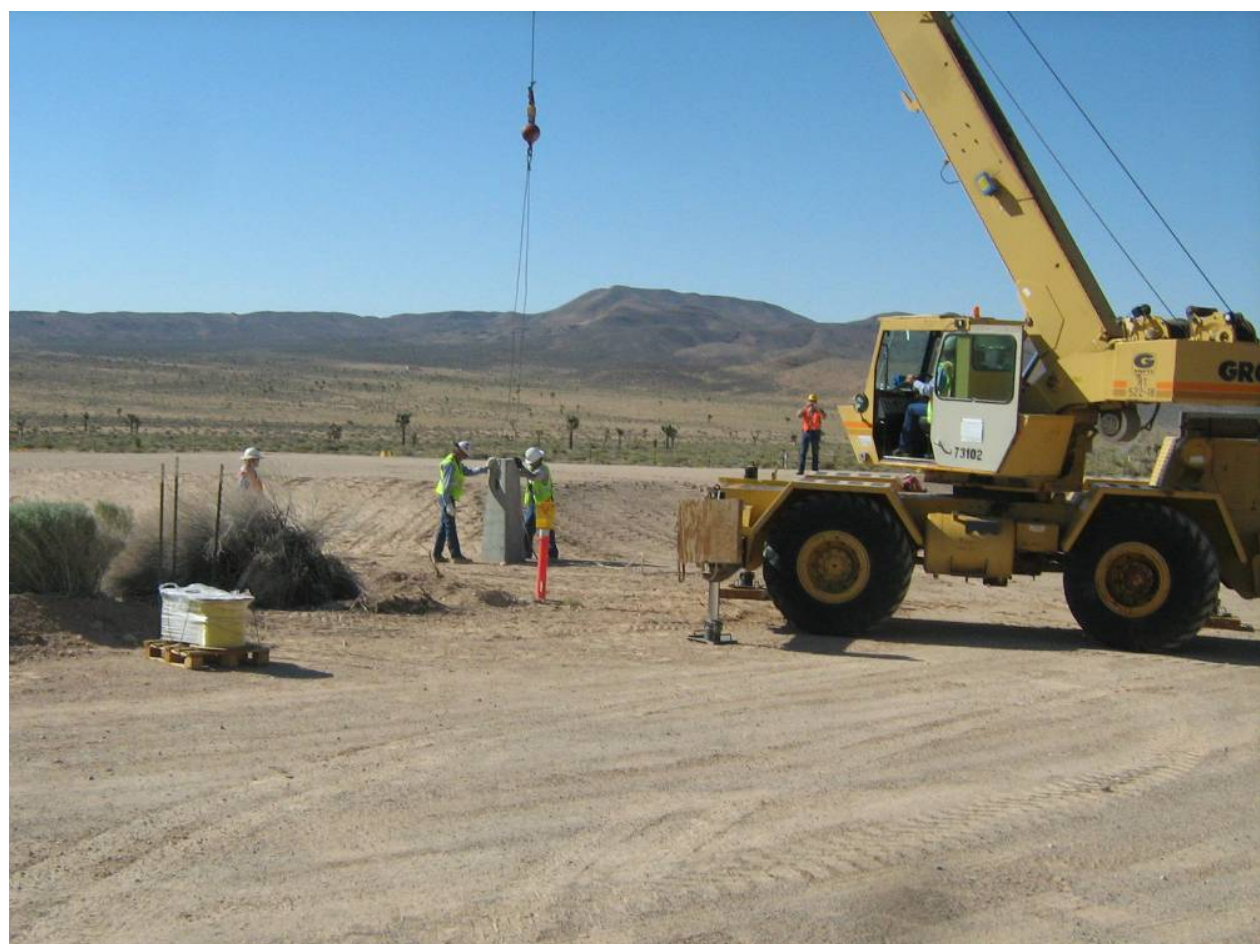

Photograph 20: Placement of Concrete Monuments at CAS 11-08-01, CWD \#1, 05/14/2013 


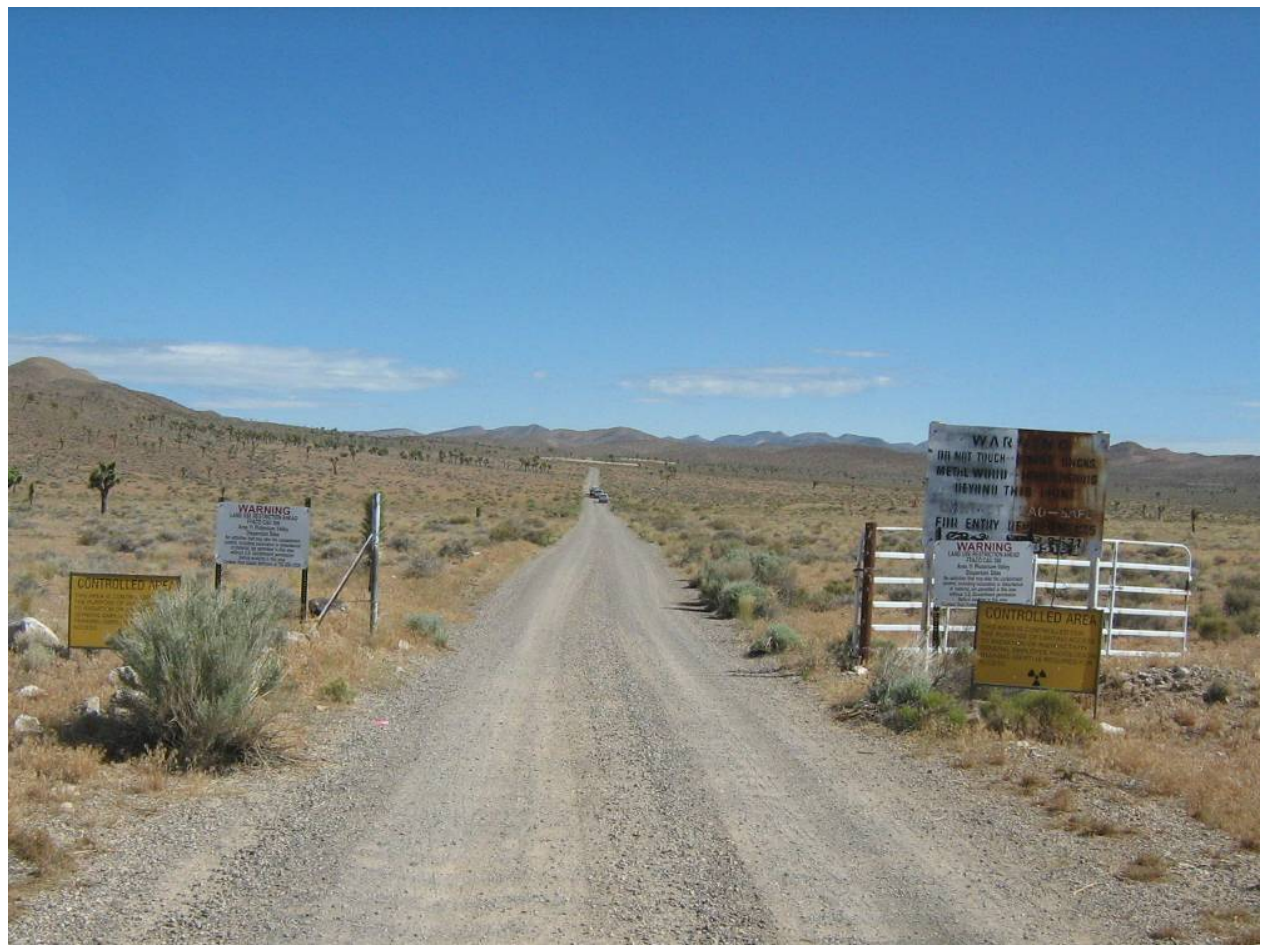

Photograph 21: Use Restriction Warning Signs at the Gate on the Road Leading to the Site, 05/29/2013

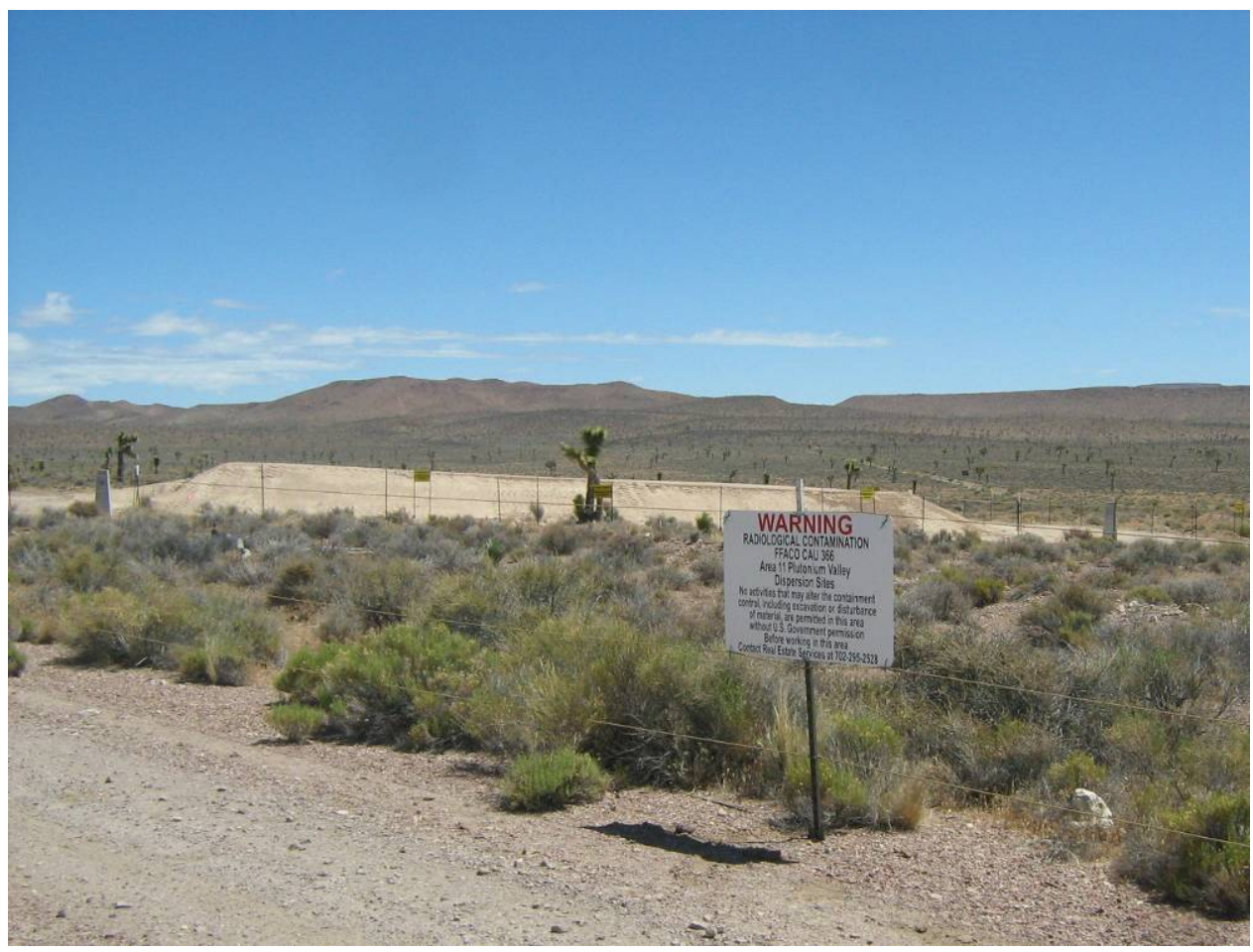

Photograph 22: Use Restriction Warning Signs on Contamination Area Fence, 05/29/2013 


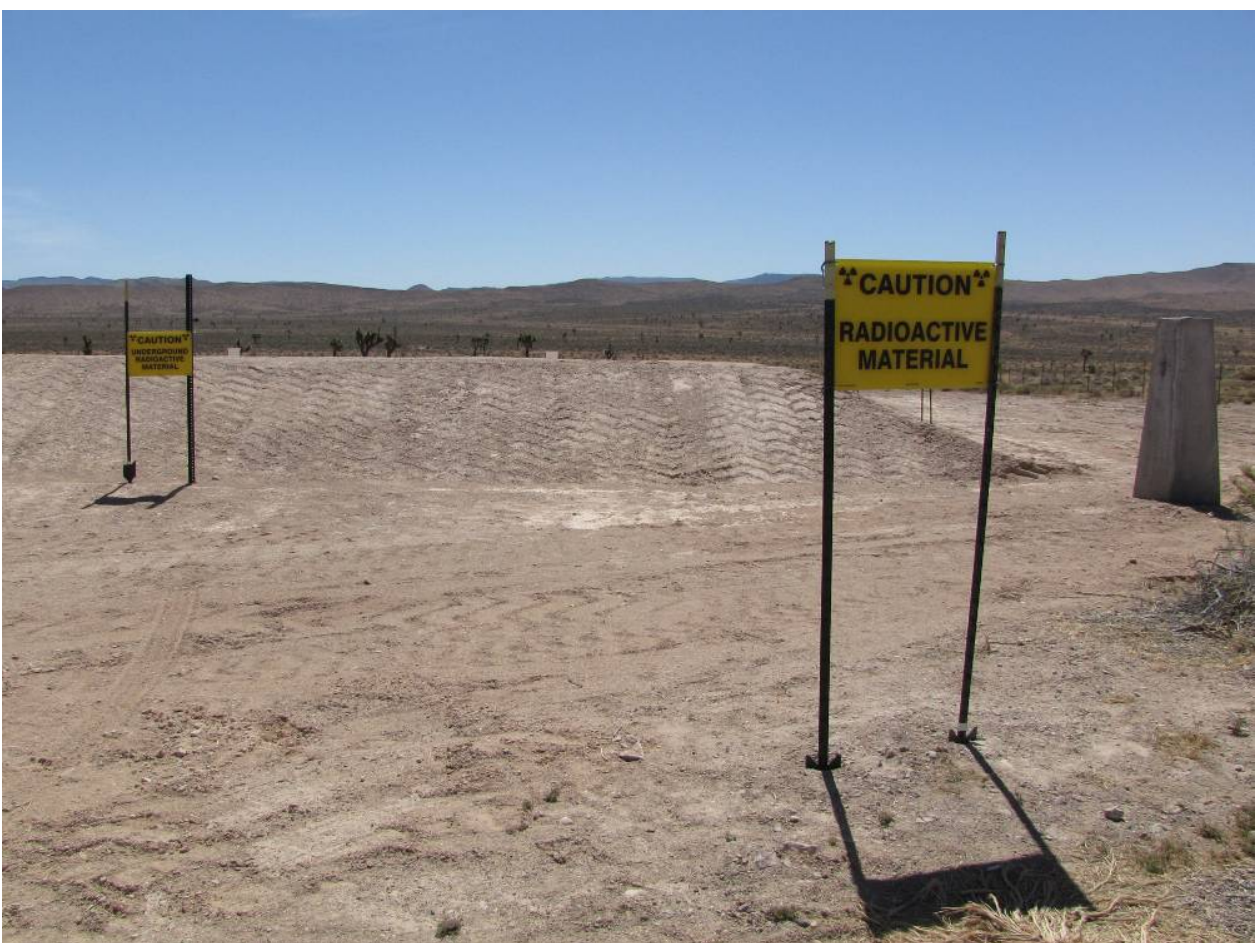

Photograph 23: Radiological Postings at CAS 11-08-01, CWD \#1, 05/30/2013

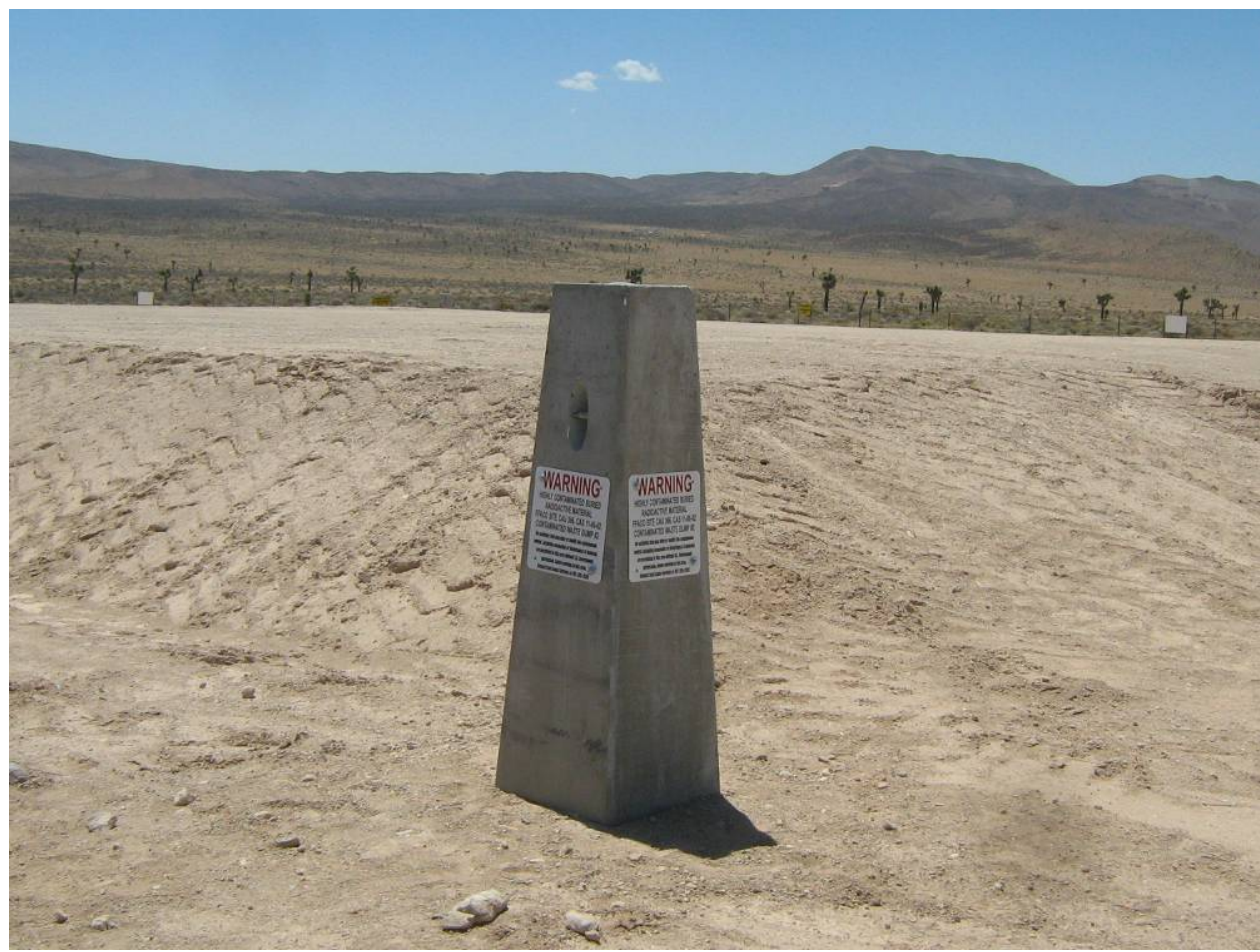

Photograph 24: Use Restriction Warning Signs on Concrete Monument at CAS 11-08-01, CWD \#1, 06/10/2013 
CAU 366 Closure Report

Section: Appendix D

Revision: 0

Date: December 2013

\section{APPENDIX D}

\section{USE RESTRICTION DOCUMENTATION}


CAU 366 Closure Report

Section: Appendix D

Revision: 0

Date: December 2013

THIS PAGE INTENTIONALLY LEFT BLANK 


\section{Use Restriction Information}

CAU Number/Description: CAU 366/Area 11 Plutonium Valley Dispersion Sites

Applicable CAS Number/Description: CAS 11-08-01/Contaminated Waste Dump \#1 CAS 11-08-02/Contaminated Waste Dump \#2 CAS 11-23-02/Radioactively Contaminated Area B CAS 11-23-03/Radioactively Contaminated Area C CAS 11-23-04/Radioactively Contaminated Area D

Contact (DOE AL/Activity): Tiffany A. Lantow/Soils

FFACO Use Restriction Physical Description:

Surveyed Area 1 - CAS 11-08-01, Contaminated Waste Dump \#1 (UTM, Zone 11, NAD 83, meters):

\begin{tabular}{|c|c|c|}
\hline \hline UR Point & Northing & Easting \\
\hline \hline Southeast & $4,091,699.85$ & $591,972.69$ \\
\hline Southwest & $4,091,714.53$ & $591,934.10$ \\
\hline West & $4,091,736.34$ & $591,934.52$ \\
\hline Northwest & $4,091,785.40$ & $591,967.18$ \\
\hline Northeast & $4,091,768.73$ & $592,008.49$ \\
\hline
\end{tabular}

Depth: 6 feet

Survey Source (GPS, GIS, etc): $\underline{\text { GIS }}$

Surveyed Area 2 - CAS 11-08-02, Contaminated Waste Dump \#2 (UTM, Zone 11, NAD 83, meters):

\begin{tabular}{|c|c|c|}
\hline \hline UR Point & Northing & Easting \\
\hline South & $4,091,916.27$ & $592,015.47$ \\
\hline West & $4,091,939.34$ & $591,981.08$ \\
\hline North & $4,091,972.48$ & $592,001.63$ \\
\hline East & $4,091,954.02$ & $592,033.51$ \\
\hline
\end{tabular}

Depth: 6 feet

Survey Source (GPS, GIS, etc): $\underline{\text { GIS }}$

Surveyed Area 3 - CAS 11-23-02, Radioactively Contaminated Area B (UTM, Zone 11, NAD 83, meters):

\begin{tabular}{|c|c|c|}
\hline UR Point & Northing & Easting \\
\hline Southeast & $4,093,120.25$ & $592,678.27$ \\
\hline South & $4,093,065.02$ & $592,656.44$ \\
\hline Southwest & $4,093,101.63$ & $592,544.06$ \\
\hline West & $4,093,212.40$ & $592,502.32$ \\
\hline Northwest & $4,093,285.93$ & $592,514.84$ \\
\hline Northeast & $4,093,244.83$ & $592,659.33$ \\
\hline
\end{tabular}

Depth: 1 foot

Survey Source (GPS, GIS, etc): $\underline{\text { GIS }}$

Surveyed Area 4 - CAS 11-23-03, Radioactively Contaminated Area C (UTM, Zone 11, NAD 83, meters):

\begin{tabular}{|c|c|c|}
\hline UR Point & Northing & Easting \\
\hline Southeast & $4,092,565.20$ & $592,856.92$ \\
\hline South 1 & $4,092,547.50$ & $592,793.56$ \\
\hline South 2 & $4,092,654.24$ & $592,713.65$ \\
\hline South 3 & $4,092,603.44$ & $592,651.43$ \\
\hline Southwest & $4,092,606.87$ & $592,609.19$ \\
\hline West & $4,092,639.97$ & $592,600.05$ \\
\hline North & $4,092,839.19$ & $592,850.64$ \\
\hline Northeast & $4,092,852.32$ & $592,918.57$ \\
\hline
\end{tabular}

Depth: 1 foot

Survey Source (GPS, GIS, etc): $\underline{\text { GIS }}$ 
Surveyed Area 5 - CAS 11-23-04, Radioactively Contaminated Area D (UTM, Zone 11, NAD 83, meters):

\begin{tabular}{|c|c|c|}
\hline \hline UR Point & Northing & Easting \\
\hline \hline Southeast & $4,092,158.21$ & $593,076.68$ \\
\hline South & $4,092,090.28$ & $592,973.37$ \\
\hline Southwest & $4,092,089.71$ & $592,937.40$ \\
\hline West 1 & $4,092,138.23$ & $592,888.31$ \\
\hline West 2 & $4,092,240.97$ & $592,877.47$ \\
\hline West 3 & $4,092,328.31$ & $592,899.16$ \\
\hline Northwest & $4,092,533.80$ & $592,853.50$ \\
\hline Northeast & $4,092,556.06$ & $593,062.98$ \\
\hline
\end{tabular}

Depth: 1 foot

Survey Source (GPS, GIS, etc): $\underline{\text { GIS }}$

\section{Basis for FFACO URs:}

Summary Statement: FFACO use restrictions (URS) were implemented for areas where the total effective dose (TED) exceeds the final action level (FAL) of 25 millirems per Occasional Use Area year (mrem/OU-yr). The FFACO URs are located within the large, fenced Contamination Area (CA) that encompasses Plutonium Valley. UR warning signs were posted along the existing CA fence and at the locked gate on the road leading to the site. The FFACO URs include buried radiologically contaminated debris within Contaminated Waste Dump (CWD) \#1, CWD \#2, and a mound adjacent to CWD \#1. The FFACO URs also include assumed radiological contaminants present within the High Contamination Areas (HCAs) associated with Test Areas 11b, 11c, and 11d and the isopleth of the aerial radiological survey that corresponds to the isopleth in which radiological debris is located outside the fence and adjacent to the Test Area 11c HCA that exceeds the FAL of $25 \mathrm{mrem} / \mathrm{OU}-\mathrm{yr}$. No activities except required post-closure inspections and repairs are permitted within the FFACO UR boundaries without prior notification to and approval from NDEP.

Contaminants Table:

\begin{tabular}{|c|c|c|c|}
\hline \hline \multicolumn{3}{|c|}{ Maximum Dose for CAU 366 } \\
\hline \hline Constituent & $\begin{array}{c}\text { Maximum 95\% Upper } \\
\text { Confidence Limit of } \\
\text { Total Effective Dose* }\end{array}$ & Action Level & Units \\
\hline Total Effective Dose & 30.6 & 25 & mrem/OU-yr \\
\hline
\end{tabular}

*Highest measured value. Higher doses may be present within the HCAs associated with Test Areas 11b, 11c, and $11 d$.

Site Controls: UR warning signs are attached to the concrete monuments located at the corners of the soil covers at CWD \#1 and CWD \#2. UR warning signs are posted along the existing three-strand wire CA fence that encompasses Plutonium Valley and at the locked gate on the road leading to the site.

\section{FFACO UR Maintenance Requirements:}

Description: Annual inspections will be performed to verify that the UR warning signs are in place and legible and that the UR is maintained. The soil covers will be inspected for cracks, animal burrows, and other signs of erosion. Maintenance or repair needs that are identified, such as sign or post repair, fence repair, or soil cover maintenance, will be completed prior to the following inspection. This UR is recorded in the FFACO database, the NNSA/NFO Management and Operations (M\&O) GIS, and the NNSA/NFO CAU/CAS files.

Inspection/Maintenance Frequency: Annual 
Administrative Use Restriction Physical Description:

Surveyed Area (UTM, Zone 11, NAD 83, meters):

\begin{tabular}{|c|c|c|}
\hline UR Point & Northing & Easting \\
\hline \hline Southeast & $4,091,790.815$ & $593,834.713$ \\
\hline South & $4,091,043.777$ & $592,051.292$ \\
\hline Southwest & $4,091,109.314$ & $591,907.266$ \\
\hline West 1 & $4,091,789.763$ & $591,892.415$ \\
\hline West 2 & $4,092,935.571$ & $591,938.711$ \\
\hline Northwest & $4,093,724.695$ & $592,415.342$ \\
\hline North 1 & $4,093,703.652$ & $592,545.810$ \\
\hline North 2 & $4,093,895.146$ & $592,583.688$ \\
\hline North 3 & $4,094,000.362$ & $592,924.590$ \\
\hline Northeast & $4,093,911.980$ & $593,196.048$ \\
\hline East 1 & $4,093,009.941$ & $593,418.570$ \\
\hline East 2 & $4,092,959.575$ & $593,704.739$ \\
\hline East 3 & $4,092,341.097$ & $594,040.937$ \\
\hline
\end{tabular}

Depth: 1 foot

Survey Source (GPS, GIS, etc): $\underline{\text { GIS }}$

\section{Basis for Administrative UR:}

Summary Statement: An administrative UR was implemented as a best management practice for the areas where the TED exceeds 25 millirems per Industrial Area year (mrem/IA-yr) and where removable contamination is present that exceeds the criterion for a CA. The administrative UR will prevent inadvertent exposure of workers to radioactivity if a more intensive use of the site is considered in the future. The current land use of the areas within the administrative UR boundary at this site does not require site workers to be present for the amount of time that would cause a worker to receive a 25-mrem dose. However, as a best management practice, the administrative UR will prevent a future (more intensive) use of the area. Personnel are restricted from performing any work in the area that would result in a more intensive use of the site than the current land use (i.e., activities consistent with the Occasional Use Area exposure scenario). Activities permitted under the current land use include short duration activities such as site visits, maintenance of UR postings, maintenance of the radiological demarcation fence and postings, road repairs, radiological training activities, soil sampling, radiological surveys, and work on utilities. Permission to conduct any restricted activities within this area requires prior notification to and approval from NDEP.

Contaminants Table:

\begin{tabular}{|c|c|c|c|}
\hline \hline \multicolumn{4}{|c|}{ Maximum Dose for CAU 366 } \\
\hline \hline Constituent & $\begin{array}{c}\text { Maximum 95\% Upper } \\
\text { Confidence Limit of } \\
\text { Total Effective Dose* }\end{array}$ & Action Level & Units \\
\hline Total Effective Dose & 515.3 & 25 & $\mathrm{mrem} / \mathrm{IA}-\mathrm{yr}$ \\
\hline
\end{tabular}

${ }^{*}$ Highest measured value. Higher doses may be present within the HCAs associated with Test Areas 11b, 11c, and $11 \mathrm{~d}$.

Site Controls: No physical site controls are required for the administrative UR other than the administrative controls for land use at the NNSS.

\section{Administrative UR Maintenance Requirements:}

Description: The administrative UR does not require postings or inspections. This UR is recorded in the FFACO database, the NNSA/NFO M\&O GIS, and the NNSA/NFO CAU/CAS files.

Inspection/Maintenance Frequency: None 
The future use of any land related to this Corrective Action Unit (CAU), as described by the above surveyed location, is restricted from any DOE or Air Force activity that may alter or modify the containment control as approved by the State and identified in the CAU CR or other CAU documentation unless appropriate concurrence is obtained in advance.

Comments: See the Closure Report for additional information.

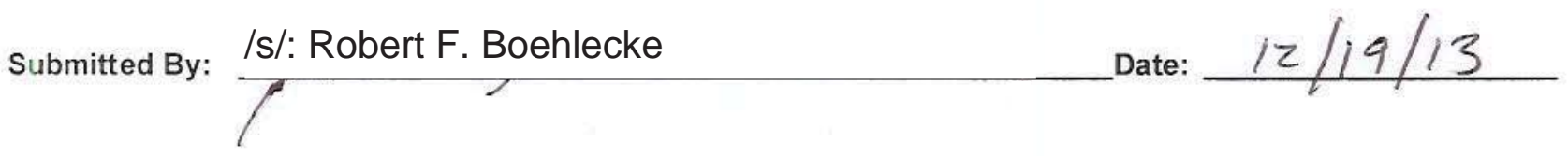




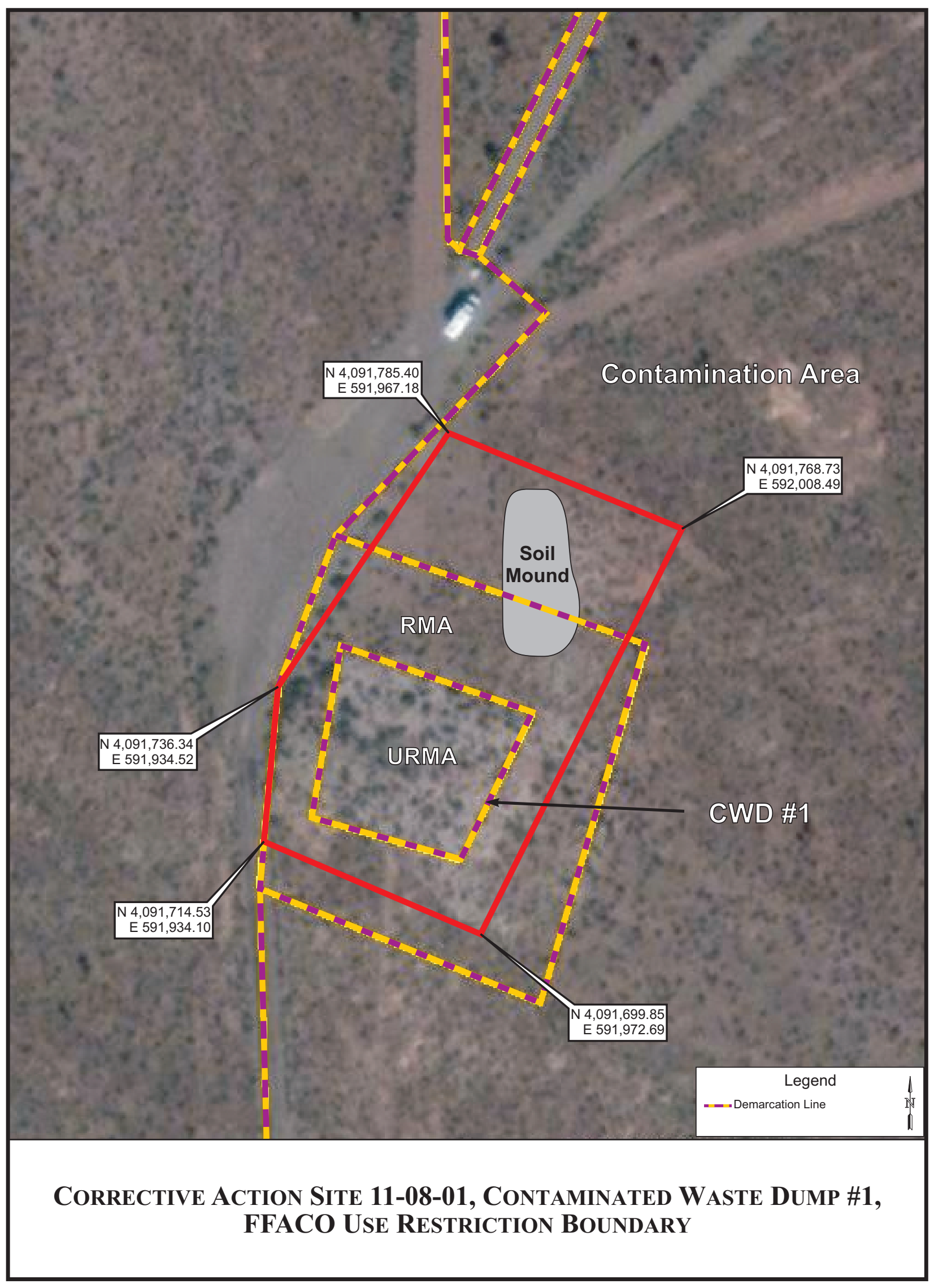




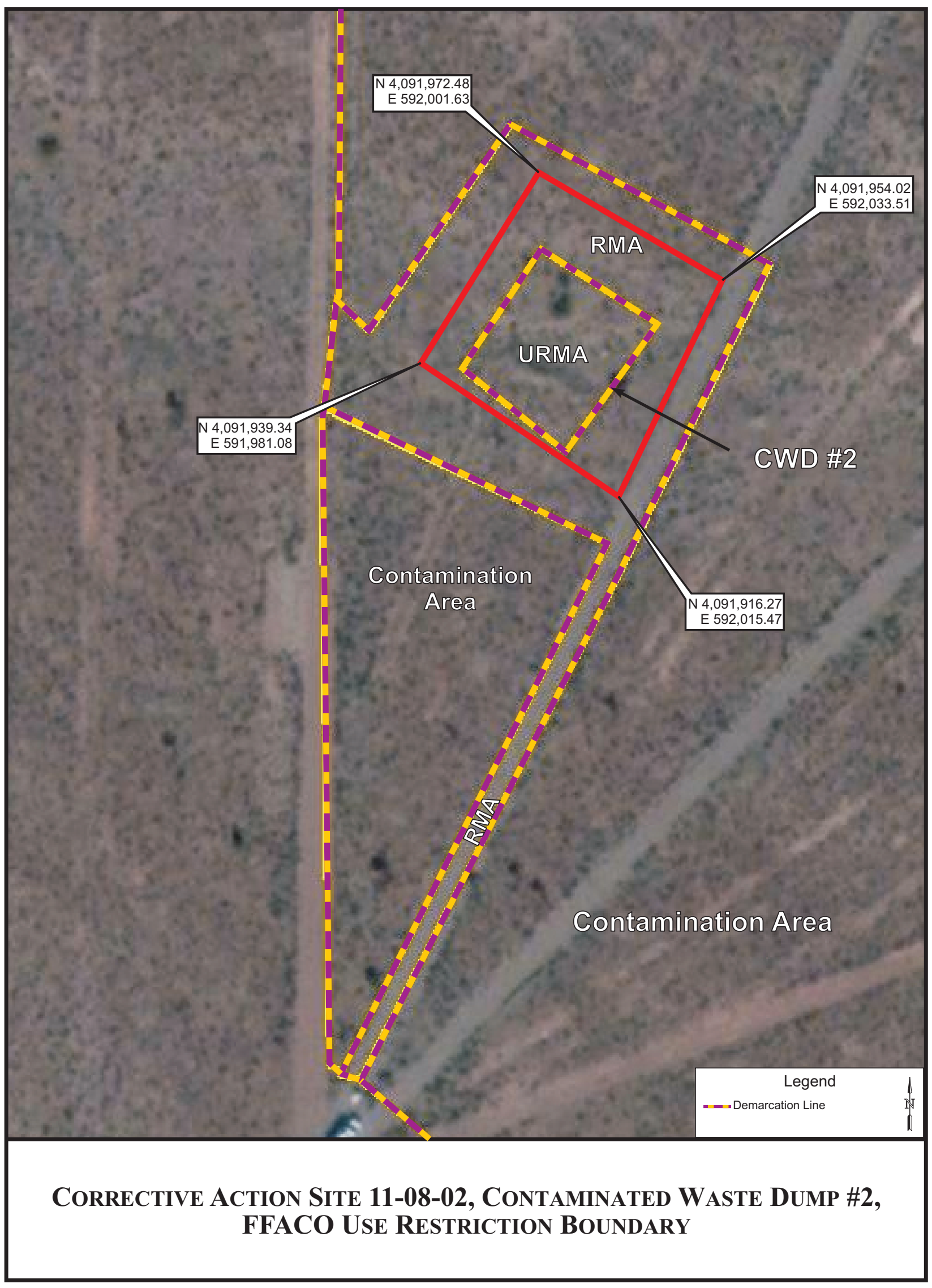




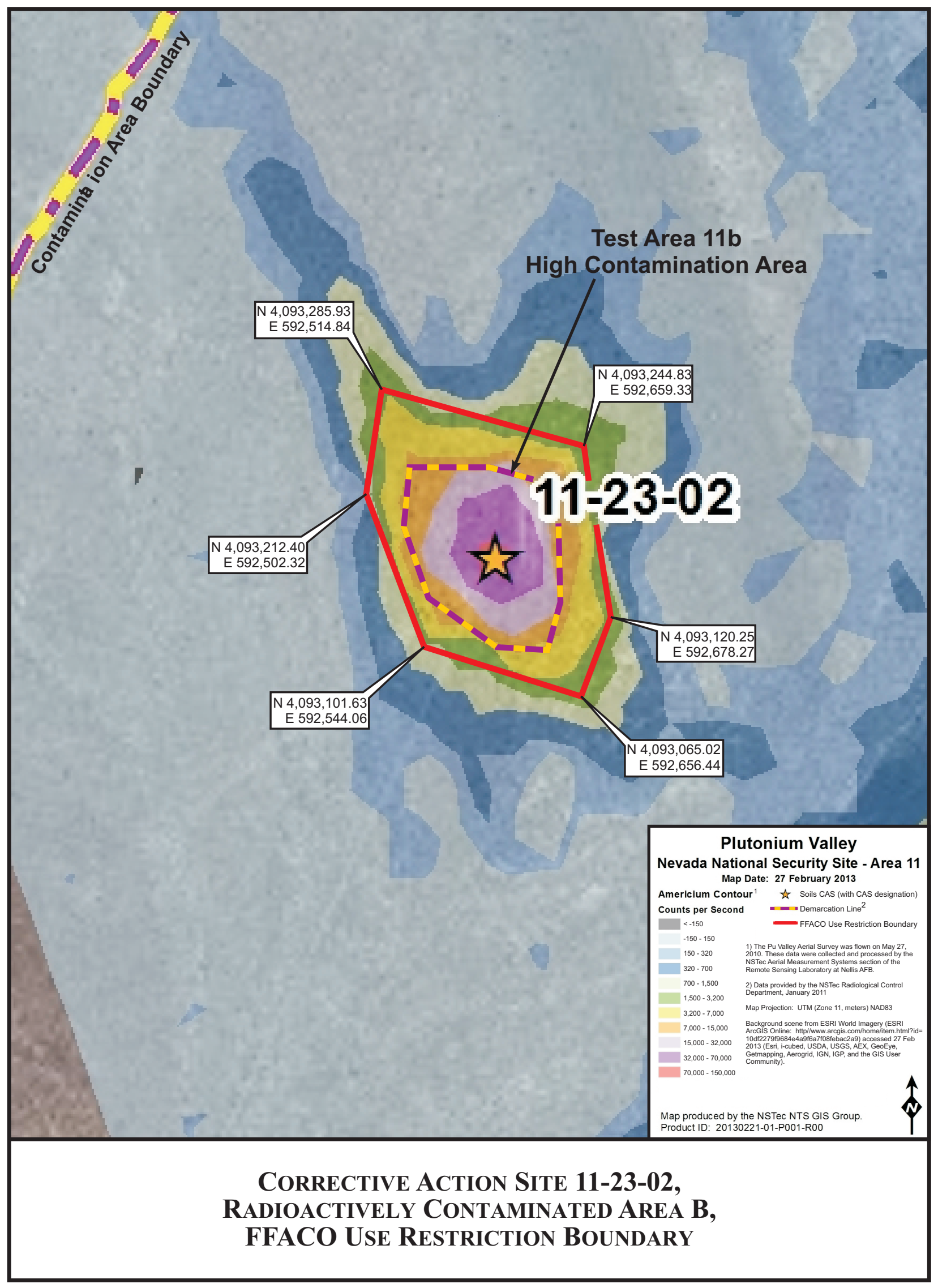




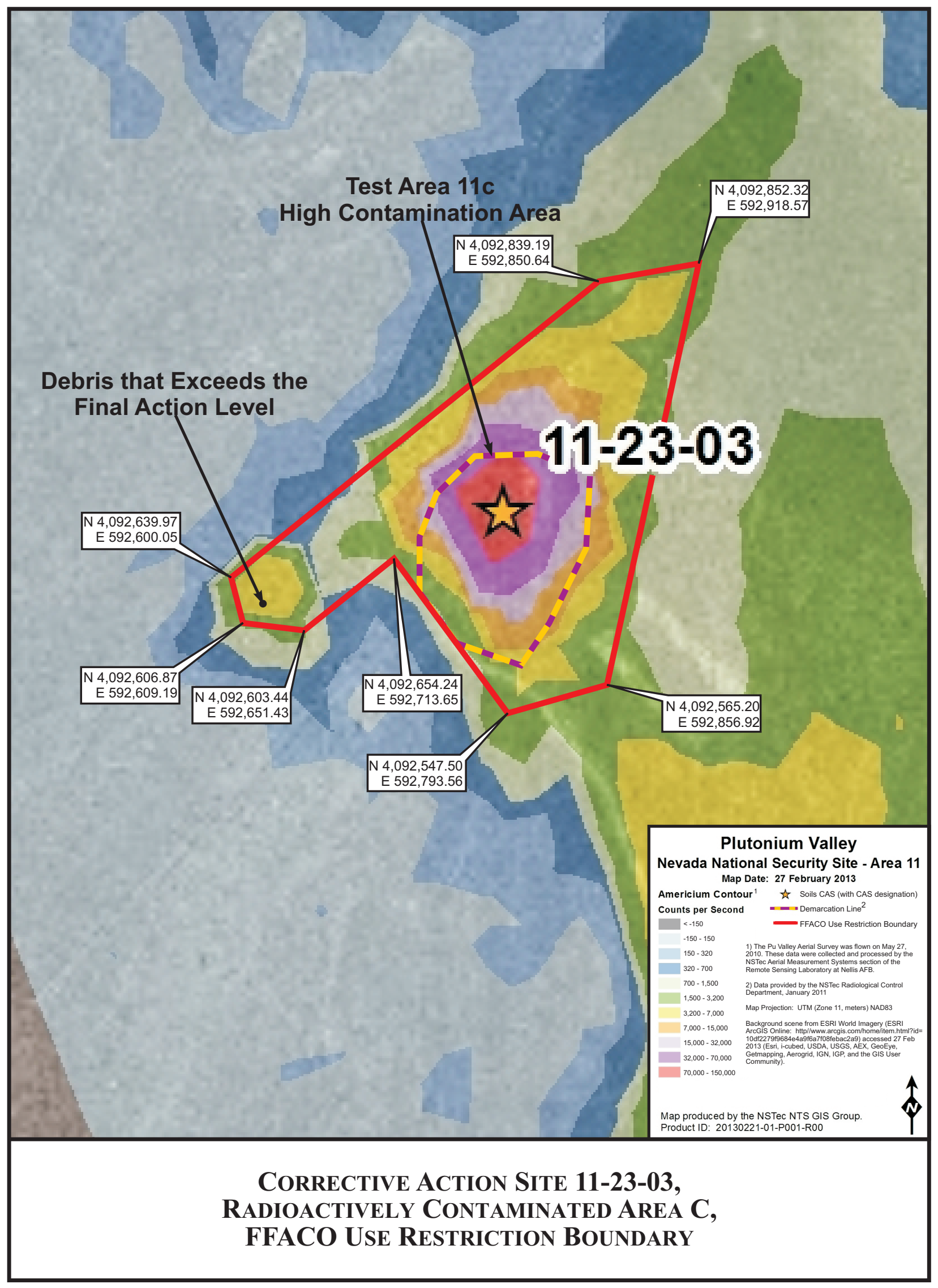




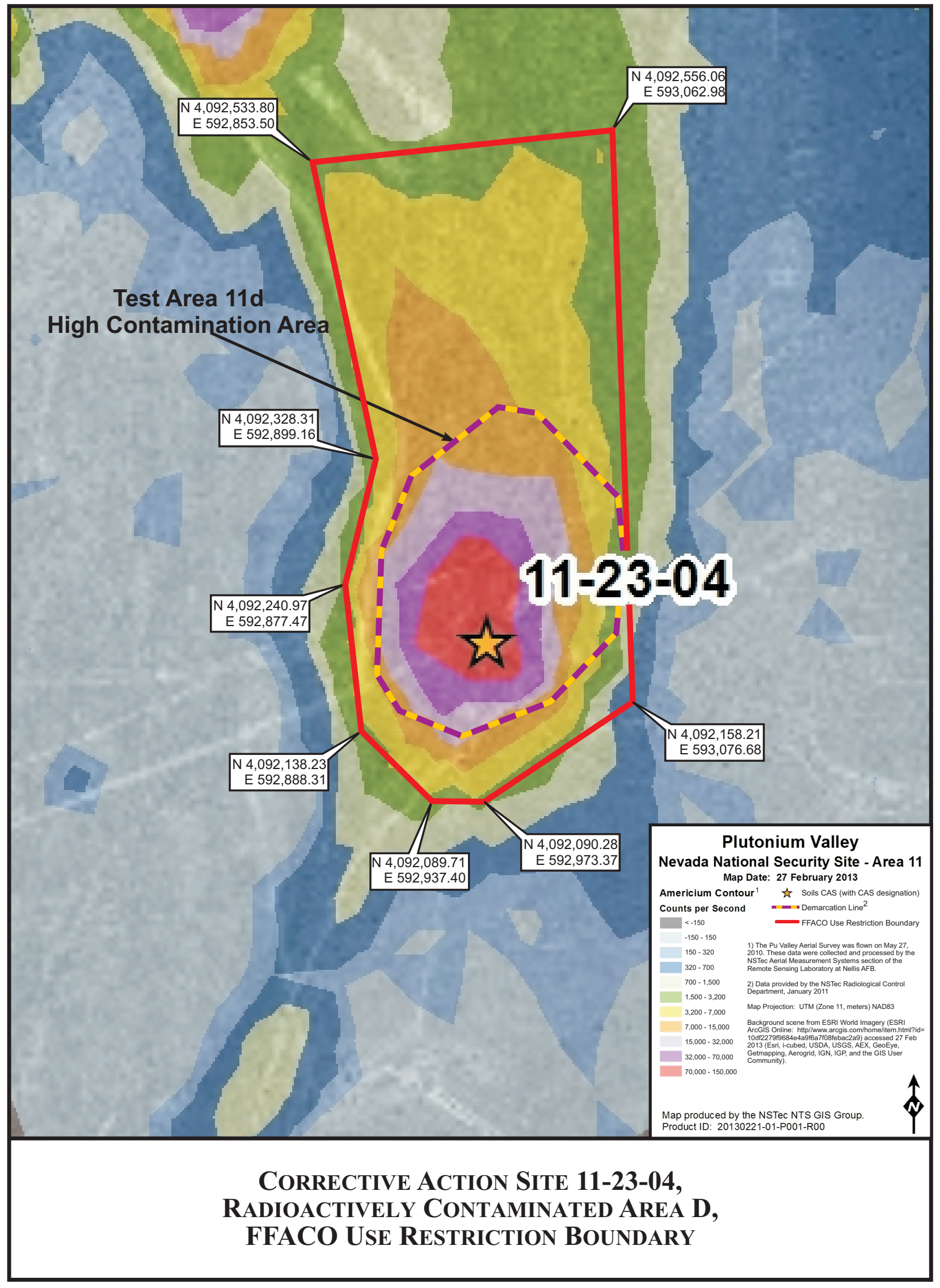




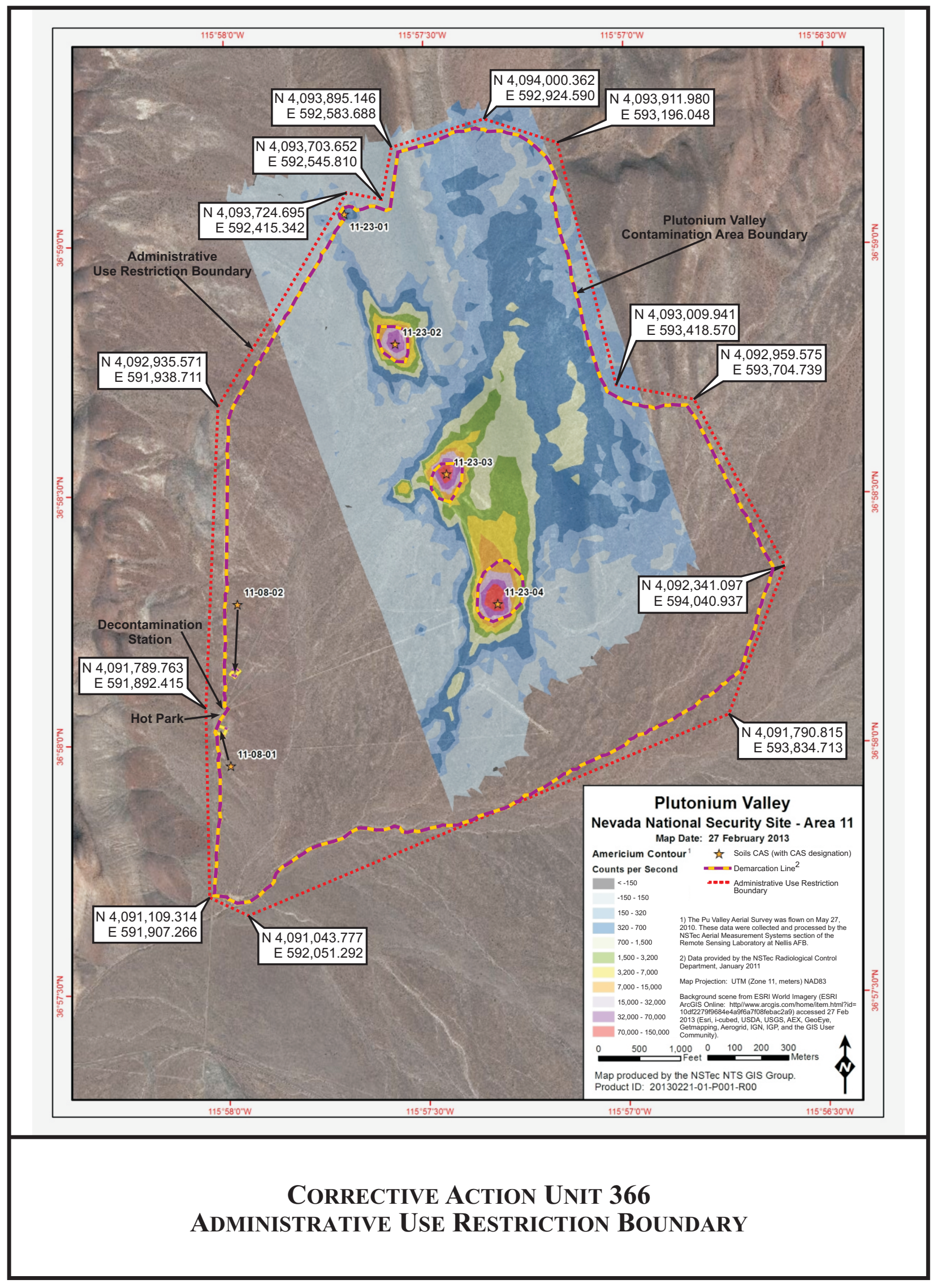




\section{APPENDIX E}

\section{NEVADA DIVISION OF ENVIRONMENTAL PROTECTION COMMENT RESPONSE FORM}


CAU 366 Closure Report

Section: Appendix E

Revision: 0

Date: December 2013

THIS PAGE INTENTIONALLY LEFT BLANK 


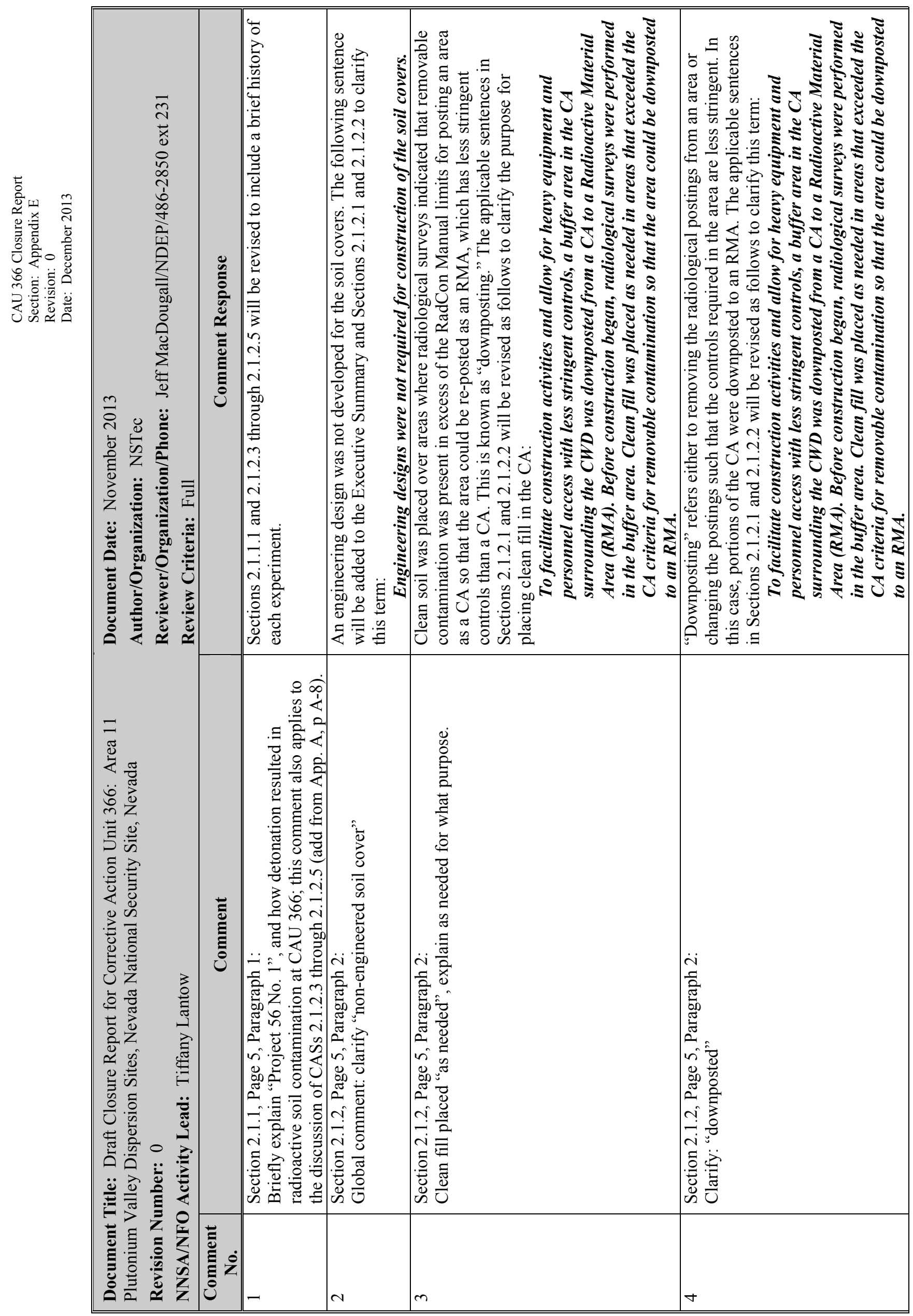




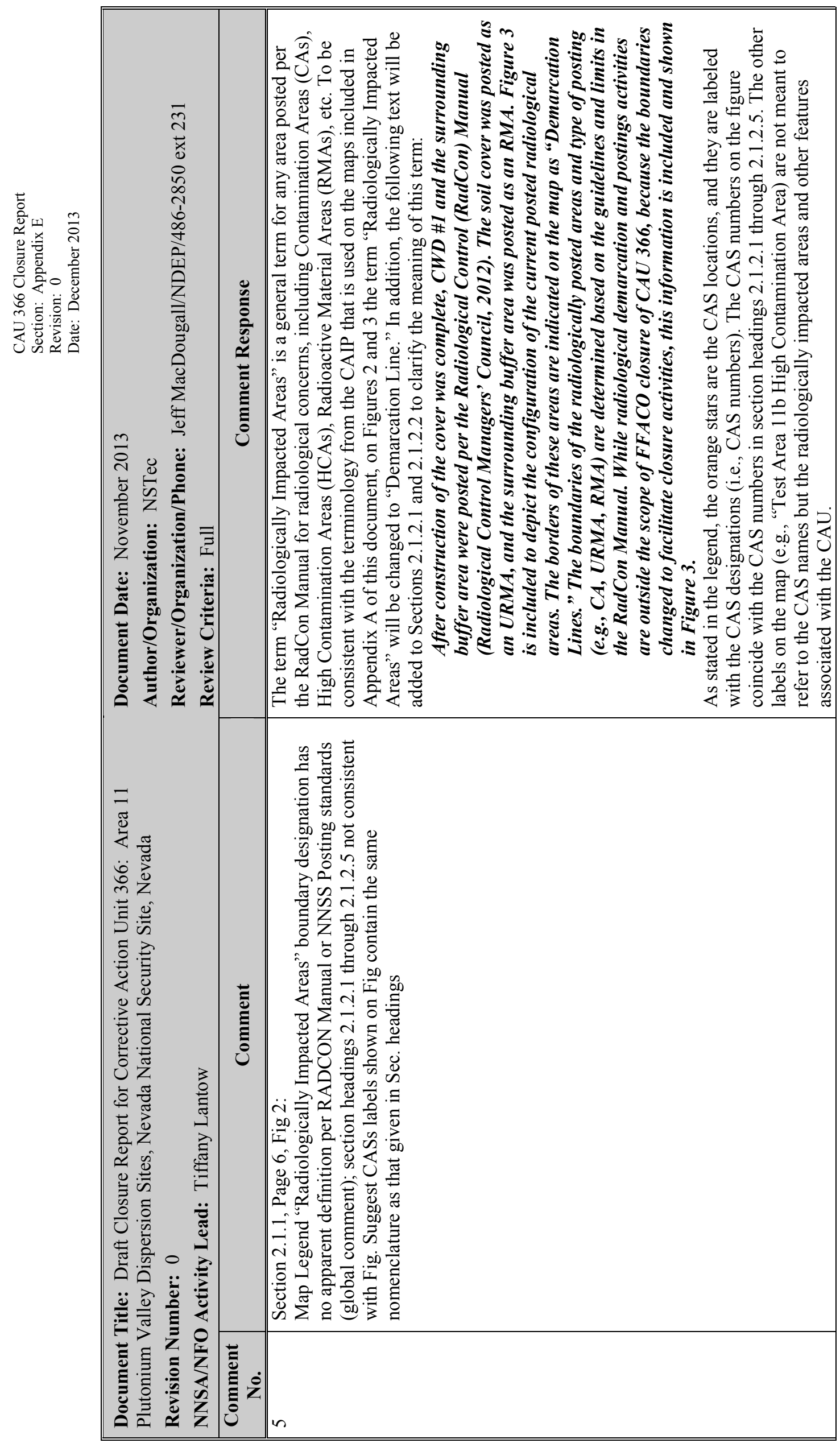




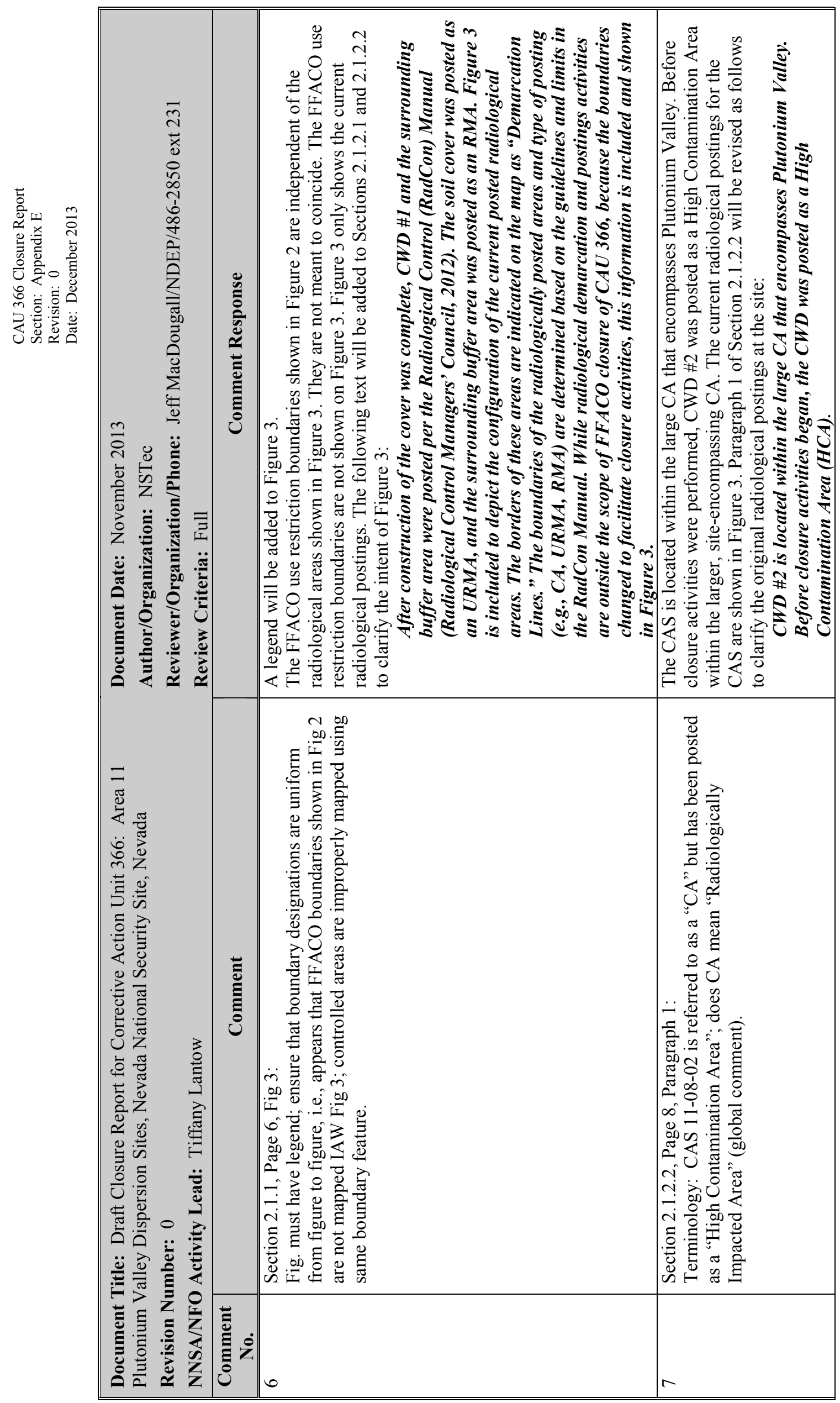




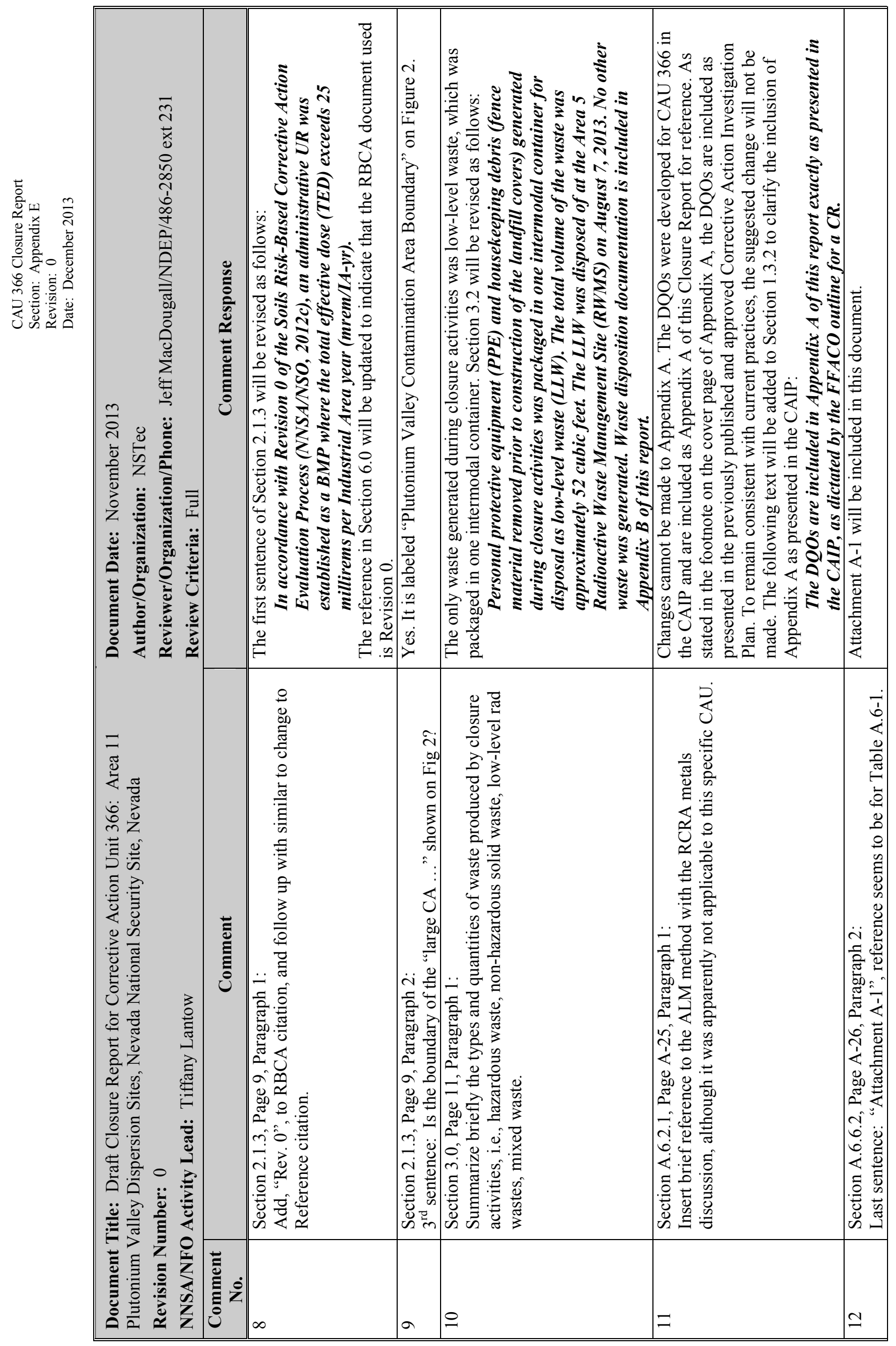




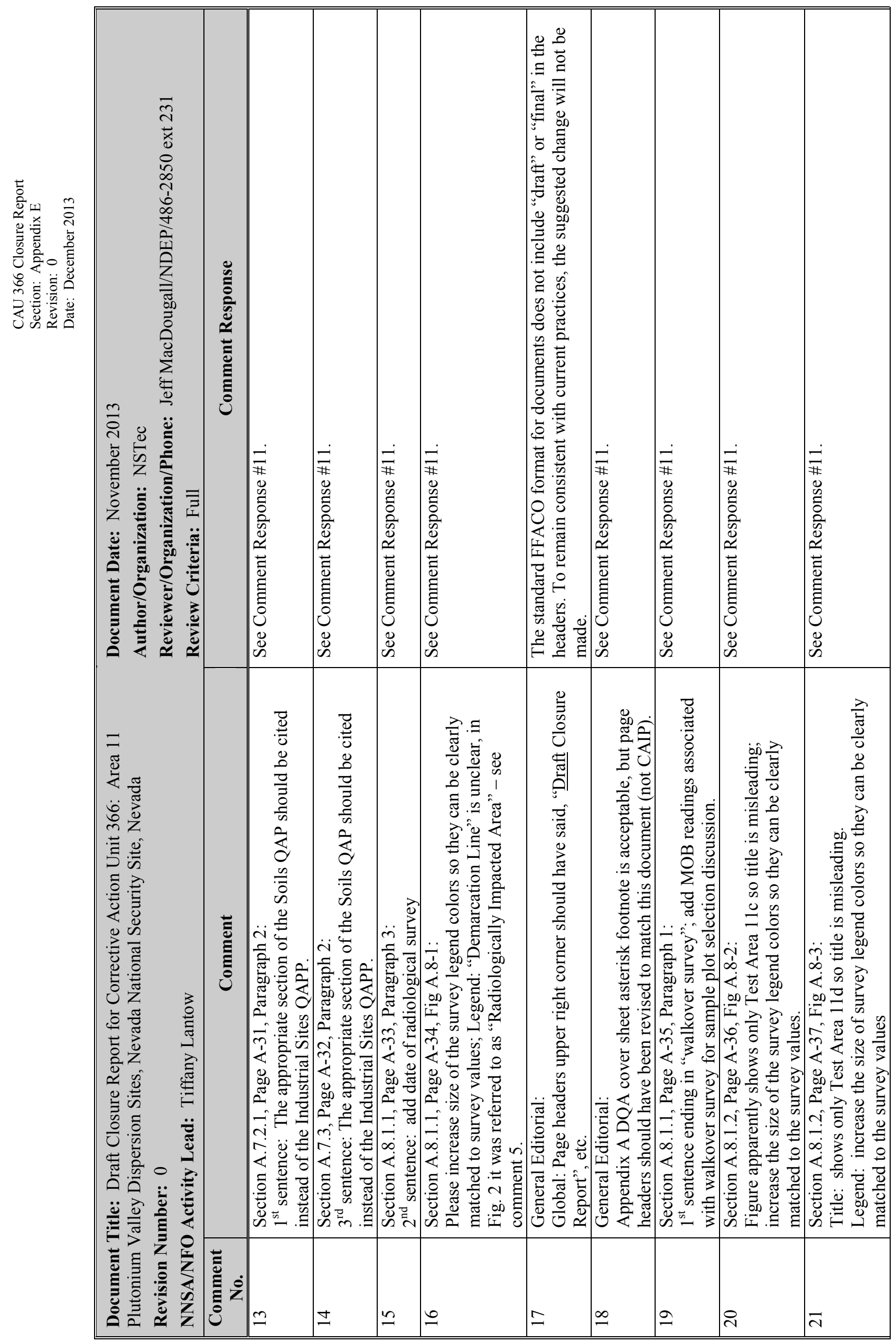




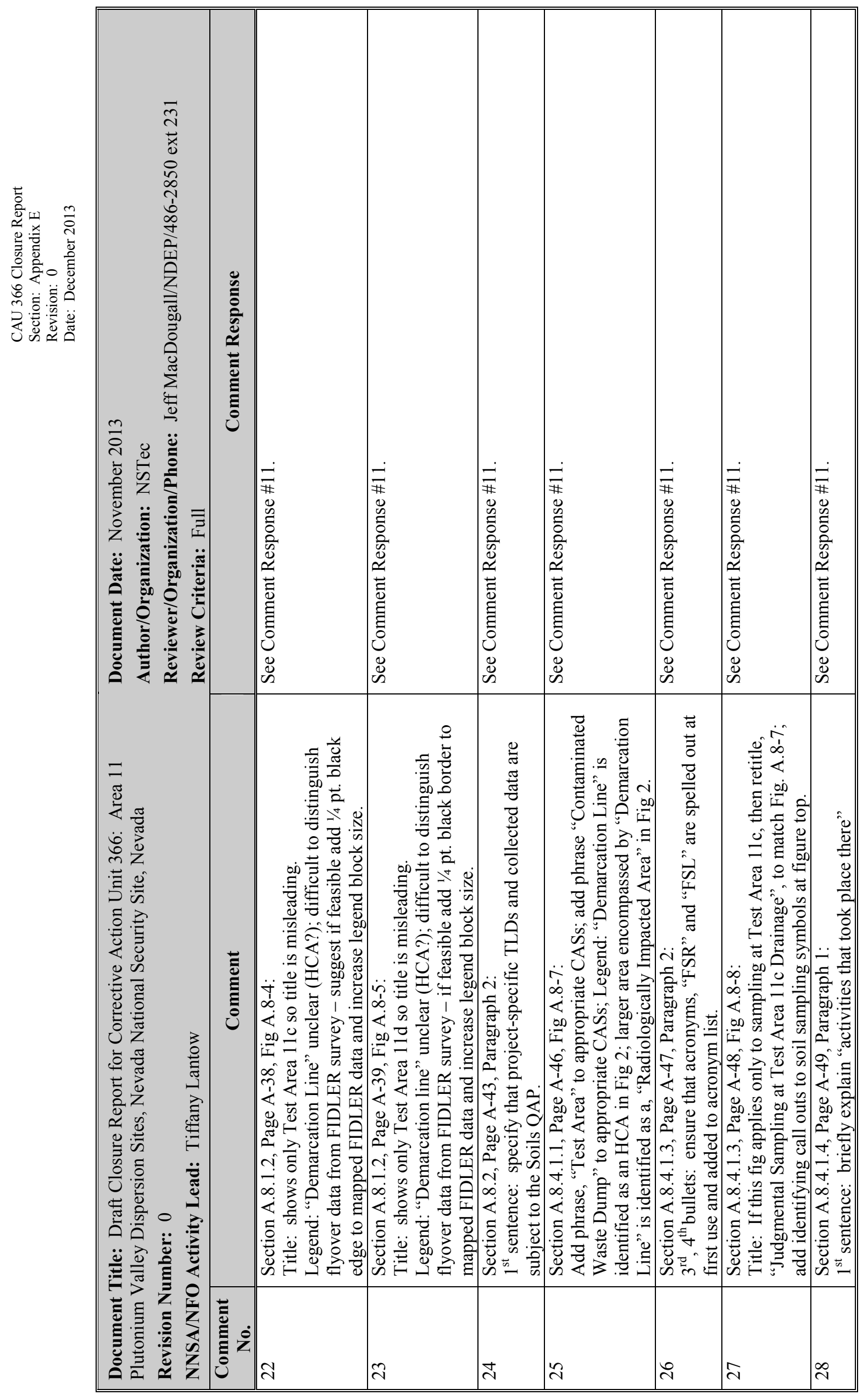


CAU 366 Closure Report

Section: Library Distribution List

Revision: 0

Date: December 2013

\section{LIBRARY DISTRIBUTION LIST}


CAU 366 Closure Report

Section: Library Distribution List

Revision: 0

Date: December 2013

\section{THIS PAGE INTENTIONALLY LEFT BLANK}




\section{LIBRARY DISTRIBUTION LIST}

U.S. Department of Energy

Office of Scientific and Technical Information

P.O. Box 62

Oak Ridge, TN 37831-0062

Southern Nevada Public Reading Facility

c/o Nuclear Testing Archive

P.O. Box 98521, M/S 400

Las Vegas, NV 89193-8521

Manager, Northern Nevada FFACO

Public Reading Facility

c/o Nevada State Library \& Archives

Carson City, NV 89701-4285
1 (Uncontrolled, electronic copy)

2 (Uncontrolled, electronic copies)

1 (Uncontrolled, electronic copy) 
CAU 366 Closure Report

Section: Library Distribution List

Revision: 0

Date: December 2013

\section{THIS PAGE INTENTIONALLY LEFT BLANK}

